\title{
DISCLAIMER
}

This report was prepared as an account of work sponsored by an agency of the United States Government. Neither the United States Government nor any agency thereof, nor any of their employees, makes any warranty, express or implied, or assumes any legal liability or responsibility for the accuracy, completeness, or usefulness of any information, apparatus, product, or process disclosed, or represents that its use would not infringe privately owned rights. Reference herein to any specific commercial product, process, or service by trade name, trademark, manufacturer, or otherwise does not necessarily constitute or imply its endorsement, recommendation, or favoring by the United States Government or any agency thereof. The views and opinions of authors expressed herein do not necessarily state or reflect those of the United States Government or any agency thereof.

\section{THE ROLE OF ACTINIDE BURNING AND THE INTEGRAL FAST REACTOR IN THE FUTURE OF NUCLEAR POWER}

\author{
by \\ William R. Hollaway \\ Lawrence M. Lidsky \\ Marvin M. Miller
}

December 1990

Program for Advanced Nuclear Power Studies

This document is

Massachusetts Institute of Technology

PUBLICLY RELEASABLE

3 Steele

Authorizing Ofticial

Date:

$9 \cdot 12 \cdot 0 t$ 


\section{DISCLAIMER}

This report was prepared as an account of work sponsored by an agency of the United States Government. Neither the United States Government nor any agency Thereof, nor any of their employees, makes any warranty, express or implied, or assumes any legal liability or responsibility for the accuracy, completeness, or usefulness of any information, apparatus, product, or process disclosed, or represents that its use would not infringe privately owned rights. Reference herein to any specific commercial product, process, or service by trade name, trademark, manufacturer, or otherwise does not necessarily constitute or imply its endorsement, recommendation, or favoring by the United States Government or any agency thereof. The views and opinions of authors expressed herein do not necessarily state or reflect those of the United States Government or any agency thereof. 


\section{DISCLAIMER}

Portions of this document may be illegible in electronic image products. Images are produced from the best available original document. 


\section{ABSTRACT}

A preliminary assessment is made of the potential role of actinide burning and the Integral Fast Reactor (IFR) in the future of nuclear power. The development of a useable actinide burning strategy could be an important factor in the acceptance and implementation of a next generation of nuclear power.

First, the need for nuclear generating capacity is established through the analysis of energy and electricity demand forecasting models which cover the spectrum of bias from anti-nuclear to pro-nuclear. The analyses take into account the issues of global warming and the potential for technological advances in energy efficiency.

We conclude, as do many others, that there will almost certainly be a need for substantial nuclear power capacity in the $2000-2030$ time frame. We point out also that any reprocessing scheme will open up proliferation-related questions which can only be assessed in very specific contexts.

The focus of this report is on the fuel cycle impacts of actinide burning. Scenarios are developed for the deployment of future nuclear generating capacity which exploit the advantages of actinide partitioning and actinide burning. Three alternative reactor designs are utilized in these future scenarios: The Light Water Reactor (LWR); the Modular GasCooled Reactor (MGR); and the Integral Fast Reactor (IFR). Each of these alternative reactor designs is described in some detail, with specific emphasis on their spent fuel streams and the back-end of the nuclear fuel cycle. Four separation and partitioning processes are utilized in building the future nuclear power scenarios: Thermal reactor spent fuel preprocessing to reduce the ceramic oxide spent fuel to a metallic form, the conventional PUREX process, the TRUEX process, and pyrometallurgical reprocessing.

The three reactor types and four separation methods are melded into three future nuclear power scenarios which bracket a broad range. The first scenario is a steady-state future which has only self-sustaining IFRs which partition and burn the actinides they produce through their integral fuel cycle. The second scenario is a Combined Hybrid System of thermal reactors (LWRs or MGRs) in symbiosis with IFRs which are optimized for actinide burning. The IFRs in this scenario burn the actinides separated out from the thermal reactor ceramic oxide spent fuel, in addition to their own. The third scenario has thermal reactors on a once-through fuel cycle in conjunction with PUREX/TRUEX aqueous reprocessing that is used to separate out the actinide isotopes from the spent fuel waste stream prior to ultimate disposal. Flowsheets are given for each of the three scenarios.

Each of the three scenarios is first discussed in a qualitative manner, and then analyzed quantitatively. Calculations are made of the internal mass flows, and of the initial inputs and the final output streams in each scenario. All mass flows are calculated in units of $\mathrm{kg} / \mathrm{GW}-\mathrm{hr}_{e}$ generated. This provides a level field for comparison by factoring out such variables as unit thermal power rating, thermal efficiency, and capacity factor. The required reactor support ratio, the thermal reactor power to IFR power ratio, is calculated for the Combined Hybrid System developed in the second scenario.

The internal mass flows and input and output mass flow results (in $\mathrm{kg} / \mathrm{GW}-\mathrm{hr}_{e}$ ) calculated for each of the three scenarios stand as a major conclusion of this study. Of 
particular significance is the 3:1 Thermal Reactor to Integral Fast Reactor support ratio calculated for the Combined Hybrid System in the second scenario.

There are advantages and disadvantages to pursuing each of the three scenarios. Scenario 1 (IFR Only) has the advantages that it requires no uranium enrichment services and only minimal natural uranium fuel makeup, but the disadvantages that it requires the storage and buildup of excess actinide isotopes, and that as a system, it may not prove amenable to private utility operation. Scenario 2 (Thermal Reactor with IFRs as Actinide Burners) has the advantage that it combines the best aspects of thermal reactors (safety, cost, operability) and the IFR (actinide burning/waste management) in a symbiotic system, but the disadvantages that the required oxide spent fuel pyroprocessing technology is experimentally unproven and that the cycle requires the storage of large quantities of uranium spiked with noble metal fission products. Scenario 3 (Thermal Reactor with PUREX/TRUEX Reprocessing) has the advantage that it can be done today using proven current technology, but the disadvantages that it requires the storage and buildup of significant quantities of actinide isotopes, and that PUREX/TRUEX reprocessing creates many secondary waste steams. 


\section{ACKNOWLEDGEMENTS}

The authors would like to acknowledge the help of Mengruo Zhang (MIT) in researching parts of this report.

The work done on this study by William R. Hollaway was performed under appointment to the Radioactive Waste Management Fellowship program administered by Oak Ridge Associated Universities for the U.S. Department of Energy.

The authors wish to acknowledge financial support for this study from Argonne National Laboratory under Universities Grant Number 31-109-ENG-38. 


\section{TABLE OF CONTENTS}

\section{Page}

Abstract

Acknowledgements

2

Table of Contents

List of Figures

List of Tables

Section 1 Introduction

Section 2 The Need for Nuclear Power in the Future

2.1 Overview of Future Global Energy Demand

2.2 Obstacles to Future Use of Nuclear Power

Section 3 Assumptions for Scenario Development

3.1 Assumptions and Ground Rules

3.1.1 Assumptions

3.1.2 Ground Rules

3.2 Reactor Types Used in Scenario Development 40

3.2.1 The Light Water Reactor (LWR) 40

3.2.2 The Modular Gas-Cooled Reactor (MGR) 46

3.2.3 The Integral Fast Reactor (IFR) 56

3.3 Separation Processes Used in Scenario 63 Development

3.3.1 Thermal Reactor Spent Fuel Preprocessing 64

3.3.1.1 LWR Spent Fuel Preprocessing 64

3.3.1.2 MGR Spent Fuel Preprocessing 67

3.3.2 The PUREX Process 69

3.3.3 The TRUEX Process 72

3.3.4 Pyrometallurgical Reprocessing $\quad 75$ 
TABLE OF CONTENTS (continued)

Section 4 Three Scenarios for the Future

4.1 Overview

$\begin{array}{llll}4.2 & \text { Scenario 1: } & \text { IFRs Only } & 81\end{array}$

4.3 Scenario 2: Thermal Reactors with IFRs as 86

4.4 Scenario 3: Thermal Reactors with 91 PUREX/TRUEX Reprocessing

4.5 Input, Output, and Mass Flows 98

Section 5 . Summary, Conclusions, and Recommendations for Future Work

References

Appendix A Mass Flow Calculations For Scenario 1 - IFRs Only

A-1

Appendix B Mass Flow Calculations For Scenario 2 - Thermal

B-1 Reactors with IFRs as Actinide Burners

Appendix C Mass Flow Calculations For Scenario 3 - Thermal

C-1 Reactors with PUREX/TRUEX Reprocessing 


\section{LIST OF FIGURES}

2-1 Greenhouse Gas Contributions to Global Warming 15

3-1 Fuel Assembly of a Typical Pressurized Water Reactor 42

3-2 Fuel Assembly of a Typical Boiling Water Reactor 43

3-3 MGR Prismatic Fuel Element Components 48

3-4 Ceramographic Cross Section of HTGR Coated Fuel Particle 49

3-5 The TRISO Fuel Particle Design 50

3-6 Fort St. Vrain Standard Fuel Element 51

3-7 Pebble Bed MGR Spherical Fuel Element 52

3-8 Pyrochemical Electrorefining Process for IFR Fuels 59

3-9 IFR High-Level Waste Flowsheet 61

3-10 LWR Spent Fuel Preprocessing $\quad 65$

3-11 MGR Spent Fuel Preprocessing $\quad 68$

3-12 Principle of the PUREX Process 70

3-13 Principle Steps in the PUREX Process 71

3-14 Generic TRUEX Process Flowsheet $\quad 74$

3-15 Simplified Flowsheet of Salt Transport Process for 76

3-16 Pyrochemical Electrorefining Process and Waste Treatment 78 for IFR Fuels

4-1 Scenario 1 Flowsheet (IFRs Only) 83 
LIST OF FIGURES (continued)

Page

4-2 Scenario 2 Flowsheet (Thermal Reactors with $\quad 87$ IFRs as Actinide Burners)

4-3 Scenario 3 Flowsheet (Thermal Reactors with

93 PUREX/TRUEX Reprocessing)

4-4 Scenario 1 Flowsheet with Mass Flows (IFRs Only)

4-5 Scenario 2 Flowsheet with Mass Flows

108

(Thermal Reactors with IFRs as Actinide Burners)

4-6 Scenario 3 Flowsheet with Mass Flows

111

(Thermal Reactors with PUREX/TRUEX Reprocessing)

5-1 Scenario 1 Flowsheet (IFRs Only)

118

5-2 Scenario 2 Flowsheet (Thermal Reactors with IFRs as Actinide Burners)

5-3 Scenario 3 Flowsheet (Thermal Reactors with PUREX/TRUEX Reprocessing) 


\section{LIST OF TABLES}

Page

2-1 Energy Efficiency Improvements in Selected Western Nations

2-2 Efficiency of Energy Use, Selected Countries, 1983

2-3 Overview of EPA Global Energy Scenario Assumptions

2-4 EPA Global Energy Scenarios: The Contribution of Nuclear Power and the Associated Global Warming

3-1 Characteristics of Light Water Reactor Spent Fuel Assemblies

3-3 Pebble Bed MGR Principal Reactor Core Data

4-2 Scenario 2 Input and Output Mass Flows 


\section{SECTION 1: INTRODUCTION}

The goal of this report is to provide an assessment of actinide burning using the Integral Fast Reactor (IFR). Actinide burning has two potential major effects. First, using partitioning and actinide burning to reduce the effective high-level radioactive waste hazard lifetime from on the order of 100,000 years to about 300 years could enormously simplify high-level waste disposal, and could change the direction of the domestic high-level radioactive waste management program. If actinide burning could help start the U.S. Department of Energy's waste program moving, it would represent a huge advance in time and money, as well as long-term radiological safety: Second, if the United States is to witness a next generation of civilian nuclear power plants, four major areas of concern must be addressed and satisfied: safety, cost, waste, and proliferation. The safety issue is being addressed by new passively safe reactor designs in a variety of guises: water-cooled, gascooled, and liquid metal-cooled. The cost issue is being addressed by the advanced reactor designers. This leaves the issues of waste management and proliferation, two issues that involve the back-end of the nuclear fuel cycle and are therefore inherently bound together. In order to address the issue of radioactive waste one must also address the issues of nuclear terrorism and nuclear proliferation. This report addresses both waste management and nuclear proliferation/terrorism.

The waste issue is addressed by investigating the possibilities of partitioning actinide elements from spent fuel, and actinide burning is investigated for both thermal reactor spent fuel and IFR spent fuel. We consider both aqueous processing and pyroprocessing for 
actinide separation. The issue of nuclear proliferation for both the IFR and the thermal reactor fuel cycles are discussed briefly.

Before any serious thought is given to constructing a next generation of nuclear power plants, it must first be established that there is a need for nuclear generated electricity in the future. This issue is explicitly addressed in Section 2, "The Need for Nuclear Power in the Future." Specific emphasis has been given to the potentially reduced role of fossil fuel due to environmental issues such as greenhouse warming and acid rain. The increased role of energy efficiency in "producing" energy by effectively reducing the current use of energy and electricity through technological efficiency improvements is also considered. On a global scale, the significant percentage increase in energy use of developing countries in the future, as opposed to the relatively static use in developed countries, must also be included in energy/electricity demand forecasting.

Section 3, "Assumptions for Scenario Development," details both the assumptions and the ground rules that are used to develop the actinide partitioning and burning scenarios investigated in the report. Many different techniques could be used to partition the actinides from spent nuclear fuel, and store or burn them. A limited, but representative, subset was chosen. This report considers three significant future nuclear power scenarios. The first subsection of Section 3 explicitly outlines the assumptions and the ground rules that are used in this report. The balance of Section 3 describes the technologies of the reactor design and separation processes assumed for the three future nuclear power scenarios. 
The reactor designs considered in this report are:

1. the Light Water Reactor (LWR),

2. the Modular Gas-Cooled Reactor (MGR), and

3. the Integral Fast Reactor (IFR).

The separation processes addressed are the PUREX process, the TRUEX process, and pyrometallurgical reprocessing. We also consider the preprocessing of oxide spent fuel for both aqueous and pyro- processing.

Section 4, "Three Scenarios for the Future," details the three nuclear power scenarios for actinide partitioning and burning which are developed and analyzed in this report. The first scenario involves a steady state future including only IFRs. These reactors in this system separate out and burn their own actinides in an integral fuel cycle. The second scenario represents a symbiotic electricity generating system involving thermal reactors (LWRs and MGRs) primarily as electricity generators coupled with IFRs optimized for use as Actinide Burners. The IFRs in this scenario would burn the transuranics (TRUs) extracted from the thermal reactor ceramic oxide spent fuel in addition to the actinides in their own metal alloy (IFR) spent fuel. This scenario is intended to take advantage of the best aspects of both thermal reactors (e.g., safety, cost, and operability) and IFRs (actinide burning/high-level waste management) and has been termed the "Combined Hybrid System" (CHS) in this report. The third scenario involves thermal reactors on a once through fuel cycle coupled with PUREX/TRUEX aqueous reprocessing to remove the actinides from the spent fuel waste stream before ultimate disposal. This scenario is not actually an actinide burning scenario, but can instead be thought of as an actinide partitioning and storage 
scenario. This scenario is intended to represent the best that can be done with current technology to alleviate the long-lived actinide problem facing all high-level radioactive waste management programs. The final subsection of Section 4 analyzes the mass flows in each of the three scenarios using the best currently available numerical input data for all of the reactor designs and the separation processes. The final input and output flows for each of the scenarios are explicitly calculated. All mass flows are calculated and reported in units of $\mathrm{kg} / \mathrm{GW}-\mathrm{hr}_{\boldsymbol{e}}$, or mass flow per unit electricity generated. These units factor out such variables as plant capacity factor and thermal efficiency, and provide a level playing field upon which to compare final inputs, outputs, and waste steams. The required reactor support ration, the $\mathrm{kW}-\mathrm{hr}_{e}$ of thermal reactors per $\mathrm{kW}-\mathrm{hr}_{e}$ of IFRs, is calculated for the Combined Hybrid System of Scenario 2. The supporting calculations for each of the three scenarios are shown in detail in appendices A, B, and C.

Section 5 gives a summary of the report and draws some conclusions from the results. Several recommendations are made for future work. 
SECTION 2: THE NEED FOR NUCLEAR POWER IN THE FUTURE

\subsection{Overview of Future Global Energy Demand}

Recent projections or scenarios of long-term global energy demands focus on the need to maintain economic growth, particularly in the developing countries, while minimizing the environmental impacts of energy production and use. The potential environmental impact of most concern associated with the use of fossil fuels, particularly coal, is the greenhouse effect due to increases in the atmospheric concentration of carbon dioxide $\left(\mathrm{CO}_{2}\right)$.

Major uncertainties exist in both the timing and the consequences of greenhouse warming due to $\left(\mathrm{CO}_{2}\right)$ as well as other greenhouse gases such as methane $\left(\mathrm{CH}_{4}\right)$, nitrous oxide $\left(\mathrm{N}_{2} \mathrm{O}\right)$, and chlorofluorocarbons (CFCs). (Currently, carbon dioxide accounts for approximately $50 \%$ of greenhouse warming (see Figure 2-1).) Given these uncertainties, it has been argued that the most sensible strategy from both an economic and a political point of view is to adopt measures which are desirable irrespective of the future impact of greenhouse warming [1]. In the energy sector, the most important of these are to increase the efficiency of energy production, distribution, and end-use, and to increase the utilization of energy sources which produce either less $\mathrm{CO}_{2}$ per unit energy, e.g., natural gas rather than coal, or no $\mathrm{CO}_{2}$ at all (nuclear fission, solar, and nuclear fusion).

The potential for more efficient use of energy is great in all end-use sectors, i.e., industrial, transportation, and residential/commercial in both developed and developing 
$1880-1980$

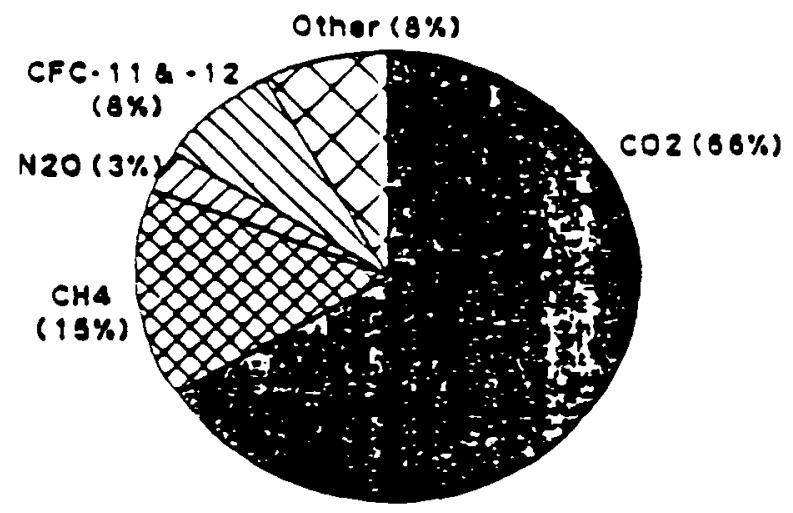

19808

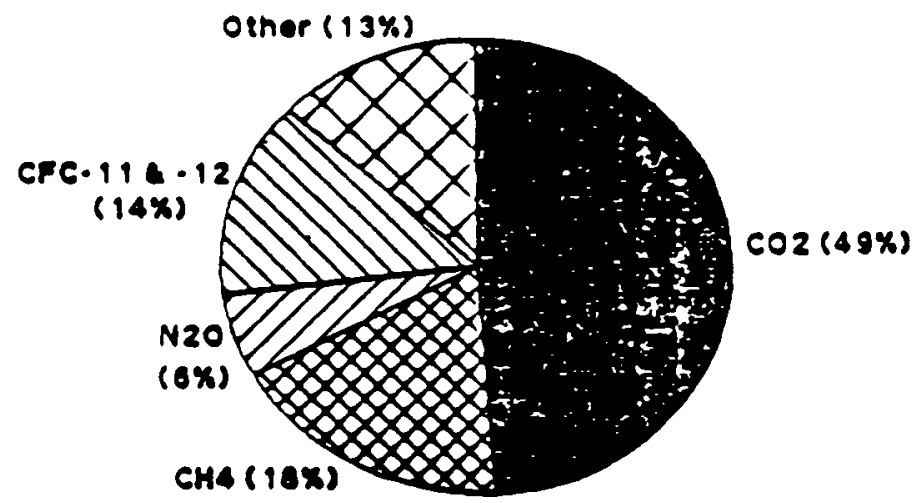

Figure 2-1: Greenhouse Gas Contributions to Global Warming

Note: The contributions are based on estimates of the increase of the concentration of each gas during the specified period. "Other" includes additional CFCs, halons, changes in ozone, and changes in stratospheric water vapor. The "other" category is quite uncertain.

Source: Policy Options for Stabilizing Global Climate, Executive Summary, D.A. Lashof and D.A. Tirpak, Editors, U.S. Environmental Protection Agency, Office of Policy, Planning, and Evaluation, Draft, February 1989, p. 12. 
countries [2]. The greatest impediment to more efficient use is not the unavailability of more efficient technologies for, e.g., steel production, electric lighting, and automotive travel, but the generally greater capital cost of these technologies compared to less energy-efficient ones [3], and the fact the energy prices are often too low to create a significant economic incentive to reduce energy consumption [4].

It is important to adopt measures to overcome these barriers to more efficient use, e.g., leasing of more efficient but more expensive light bulbs to customers from the utility, thus converting a first cost to an operating cost [5]. In the near term especially, greater energy efficiency may be the quickest and the most economic method of satisfying the demand for energy services with minimal environmental impact [6].

We note in this regard that the efficiency of energy use, measured in energy consumption per unit GNP, increased by 1-3\%/yr in many Western nations over the last 15 years (see Table 2-1), and that, by this measure, energy is still used twice as efficiently in Japan compared to the U.S., while most developing and socialist countries lag far behind in this respect (see Table 2-2).

Although it must play a significant role in solving the global energy problem, greater efficiency alone is not sufficient. In particular, efficiency is not a "renewable resource." For example, a $2 \%$ annual rate of improvement in the energy efficiency of steel-making worldwide would necessitate going beyond the thermodynamic minimum for reducing iron from ore by about the year 2075, which is of course impossible [7].

On the supply side, use of high-efficiency aeroderivative gas turbines instead of conventional coal-fired electric plants would decrease $\mathrm{CO}_{2}$ emissions per unit energy by 
Table 2-1: Energy Efficiency Improvements in Selected Western Nations

$\underline{\text { Country }} \underline{1973-1982} \underline{1982-1986}$

(Rate of Energy Efficiency Improvement, percent per year)

$\begin{array}{lcc}\text { Belgium } & 2.9 & -0.5 \\ \text { Denmark } & 2.7 & 1.4 \\ \text { F.R. of Germany } & 2.1 & -0 \\ & & \\ \text { France } & 2.6 & -0 \\ \text { Italy } & 1.3 & 1.5 \\ \text { Ireland } & 2.7 & -3.5 \\ & & \\ \text { Luxembourg } & 1.0 & 2.2 \\ \text { Netherlands } & 1.8 & -1.0 \\ \text { Portugal } & \text { na } & 1.0 \\ & & \\ \text { Spain } & \text { na } & 0.7 \\ \text { United Kingdom } & 1.9 & 1.3 \\ \text { United States } & 2.1 & 2.8^{+}\end{array}$

+Note: In 1988 this rate shifted to -0.035 .

Source: Communication from the Commission to the Council, "The Main Findings of the Commission's Review to Member States' Energy Policies," Commission of the European Communities, 6 April 1988, Brussels. 
Table 2-2: Efficiency of Energy Use, Selected Countries, 1983

Country

Market-Oriented

France

Sweden

Japan

Spain

West Germany

Italy

United Kingdom

United States
8.6

8.6

9.7

11.8

11.8

12.9

17.2

19.3

Centrally Planned

Yugoslavia

21.5

Poland

26.9

East Germany

29.0

Czechoslovakia

30.1

Soviet Union

32.3

Romania

37.6

China

40.9

Hungary

49.5

Source: W.U. Chandler, "Designing Sustainable Economies," in Sate of the World 1987, A Worldwatch Institute Report, p. 182. 
about a factor of two if gas leaks can be minimized [8]. (Methane per molecule is approximately 50 times as potent a greenhouse gas as $\mathrm{CO}_{2}$, and hence, natural gas leaks on the order of $2-4 \%$ during extraction, transmission, and end-use would negate its $\mathrm{CO}_{2}$ combustion advantage as compared to coal.) However, gas resources are substantially smaller than coal [9], and this underlines the need for further development and use of solar and nuclear technologies [10].

In this regard, most energy analysts favor either: (1) primary emphasis on energy efficiency to minimize total energy demand, with a greater relative contribution of solar as compared to nuclear on the supply side, or (2) less reliance on efficiency and a much larger nuclear contribution. For example, the global energy scenario of J. Goldemberg et al. [11] leads to a total primary energy consumption of $11.2 \mathrm{TW}$ yrs in 2020 --as compared to $11 \mathrm{TW}$ yrs in 1987--with fossil, nuclear, and solar shares of 8.2, 0.9, and $2.1 \mathrm{TW}$ yrs, respectively. The fossil contribution leads to $\mathrm{CO}_{2}$ emissions of $4.8 \mathrm{Gt} \mathrm{C/yr--as} \mathrm{compared} \mathrm{with} 6 \mathrm{Gt} \mathrm{C} / \mathrm{yr}$ in 1987--and the nuclear share corresponds to an installed capacity of $460 \mathrm{GWe}$, assuming a thermal-to-electric conversion efficiency of $1 / 3$ and a capacity factor of $65 \%$.

By contrast, the $\mathrm{CO}_{2}$-reduction scenario proposed by W. Häfele [12] envisions total primary energy use of $16 \mathrm{TW}$ yrs in 2030, with fossil, nuclear, and solar shares of 9, 3.7, and 3.3 TW yrs, respectively. The fossil contribution leads to $\mathrm{CO}_{2}$ emissions of $4.1 \mathrm{Gt} \mathrm{C} / \mathrm{yr}$. Out of the total 3.7 TW years given to nuclear power, $2.2 \mathrm{TW}$ years are allocated to electricity generation, and 1.5 TW years are for high temperature nuclear process heat. Häfele assumes a thermal efficiency of 0.4 (FBR and/or HTGR) and a capacity factor of $70 \%$ for electricity generation, and converts the high temperature heat contribution to equivalent 
electric power generation by assuming the same thermal efficiency and a load factor of $80 \%$. This gives a total of $2000 \mathrm{GWe}$ of installed nuclear capacity, more than 4 times that prescribed by Goldemberg at al.

The differences between the role of nuclear power in the Goldemberg et al. and the Häfele scenarios--which are broadly representative of those proposed by members of the anti- and pro-nuclear establishments, respectively--are even deeper than the four-fold difference in installed nuclear capacity suggests. For Goldemberg et al., the most important problem posed by the further development of nuclear power is nuclear weapons proliferation and terrorism, which unlike reactor safety and waste disposal, is viewed as not amenable to a technical fix, although it can be ameliorated by relying only on once-through fuel cycles. (This view is representative of that of many anti-nuclear "experts;" see below.) Thus, nuclear power is judged to be the "energy source of last resort," and the $460 \mathrm{GWe}$ of installed nuclear capacity in 2020 represents the "high-water mark" of nuclear development. On the other hand, Häfele et al. see a future world which is both highly electrified with a significant share provided by nuclear, as well as growing applications of nuclear hightemperature process heat.

Obviously, analysis of energy futures, including the role of particular energy sources such as nuclear power, is highly uncertain, as the unreality of many predictions made during the 1970 s attests. In order to assess the dependence of scenario results on such variables as population growth, labor productivity, price and income elasticities of energy demand, and the availability of energy resources as a function of price, it is necessary to go beyond the ad hoc methods of, e.g., Goldemberg et al. and Häfele, and to use an analytic model which 
is both transparent and reproducible.

Such a model has been developed by J. Edmonds and J. Reilly [13], and it has been widely used to assess the effectiveness and implications of policies for controlling $\mathrm{CO}_{2}$ emissions. In brief, it is a partial-equilibrium model--meaning that it solves for equilibrium between energy supply and demand, and between the energy sector and the rest of the economy--which has a high degree of disaggregation both by geographic region (9) and primary energy categories (6) and a long time horizon (to the year 2100). The model has recently been modified in order to develop four detailed global long-term energy scenarios for a report to Congress by the U.S. Environmental Protection Agency (EPA) entitled: Policy Options for Stabilizing Global Climate (Office of Policy, Planning, and Evaluation EPA, February 1989, Draft) [14]. These scenarios are known as: Slowly Changing World (SCW), Rapidly Changing World (RCW), Slowly Changing World with Policy Initiatives to Minimize Greenhouse Warming (SCWP), and a similar modification to RCW, (RCWP).

The underlying EPA scenario assumptions are listed in Table 2 of the Executive Summary of the report (reproduced here as Table 2-3), and "snapshots" of the nuclear power contribution to both total primary energy and to total installed electric capacity are summarized in Table 2-4 for the years 2050 and 2100 . It is seen that nuclear power makes a significant contribution to total energy supply, particularly in the greenhouse gas minimization strategies, SWCP and RWCP [15].

Obviously, projections of energy supply and demand, whether based on educated guesses, back-of-the-envelope calculations or the use of analytic models such as that of Edmonds and Reilly are inherently uncertain. These uncertainties compound over time, and 
Table 2-3: Overview of Global Energy Scenario Assumptions

Slowly Changing World

Slow GNP Growth

Continued Rapid Population Growth

Minimal Energy Price Increases

Slow Technological Change

Carbon-Intensive Fuel Mix

Increasing Deforestation

Montreal Protocol/Low Participation

Slowly Changing World

with Stabilizing Policies

Slow GNP Growth

Continued Rapid Population Growth

Minimal Energy Price Increases/Taxes

Rapid Efficiency Improvements

Moderate Solar/Biomass Penetration

Rapid Reforestation

CFC Phase-Out
Rapidly Changing World

Rapid GNP Growth Moderated Population Growth Modest Energy Price Increases Rapid Technological Improvements Very Carbon-Intensive Fuel Mix Moderate Deforestation Montreal Protocol/High Participation with Stabilizing Policies

Rapid GNP Growth Moderated Population Growth Modest Energy Price Increases/Taxes Very Rapid Efficiency Improvements Rapid Solar/Biomass Penetration Rapid Reforestation CFC Phase-Out

Source: $\quad$ Policy Options for Stabilizing Global Climate, Executive Summary, D.A. Lashof and D.A. Tirpak, Editors, U.S. Environmental Protection Agency, Office of Policy, Planning, and Evaluation, Draft, February 1989, p. 12. 
Table 2-4: EPA Global Energy Scenarios: The Contribution of

2050

SCBNARIO

SCW
RCW
SCWP
RCWP

\begin{tabular}{|c|c|c|c|}
\hline $\mathbf{E}_{\mathbf{N}}$ & $\mathbf{E}_{\mathbf{T}}$ & $\boldsymbol{\epsilon}_{\mathrm{NI}}$ & $\epsilon_{T I}$ \\
\hline \multicolumn{2}{|c|}{$\mathbf{E J}$} & \multicolumn{2}{|c|}{ GWe } \\
\hline 25 & 484 & 405 & 3147 \\
\hline 74 & 892 & 1195 & 6879 \\
\hline 39 & 462 & 623 & 3171 \\
\hline 98 & 749 & 1573 & 6416 \\
\hline
\end{tabular}

\begin{tabular}{|c|c|c|c|}
\hline \multicolumn{4}{|c|}{2100} \\
\hline $\mathbf{E}_{\mathbf{N}}$ & $\mathbf{E}_{\mathbf{T}}$ & $\boldsymbol{\epsilon}_{\mathrm{NI}}$ & $\epsilon_{T I}$ \\
\hline \multicolumn{2}{|c|}{ EJ } & \multicolumn{2}{|c|}{ GWe } \\
\hline 51 & 679 & 818 & 5125 \\
\hline 147 & 1411 & 2367 & 12987 \\
\hline 77 & 554 & 1235 & 4269 \\
\hline 191 & 938 & 3080 & 9723 \\
\hline
\end{tabular}

$$
\begin{aligned}
& 1985 \\
& E_{N}=15.3 \mathrm{EJ} \\
& E_{T}=314.7 \mathrm{EJ} \\
& \epsilon_{N I}=250 \mathrm{GWe} \\
& \epsilon_{T I}=1654 \mathrm{GWe}
\end{aligned}
$$

'Note: The extent of warming depends not only on the amount of greenhouse gas emissions, but also on the sensitivity of the climate system to increases in greenhouse gas concentrations. The numbers given are for a mid-range sensitivity of $3^{\circ} \mathrm{C}$ to an equivalent doubling of the $\mathrm{CO}_{2}$ concentration.

Source: $\quad$ Policy Options for Stabilizing Global Climate, Appendices, D.A. Lashof and D.A. Tirpak, Editors, U.S. Environmental Protection Agency, Office of Policy, Planning and Education, Draft, Appendix B, Tables B-23, 29, 32, 46, 52, 55, $69,75,78,92,98,101$, and 153. 
it is quite likely that the world 50 years from now will be quite different in terms of geopolitical and economic structure, as well as the status of various technologies and processes associated with energy provision and use, with marked implications for patterns of energy supply and demand. These inherent uncertainties are compounded by the fact that most energy forecasts are, in reality, largely "backcasts" [16]. That is, the driving force is either and explicit or implicit view of what constitutes a desirable energy future, and the model input assumptions with regard to, e.g., population and economic growth rates, price and income elasticities of energy demand, efficiencies of energy production and end-use, fossil fuel resources and costs, and availability and cost of solar technologies are used to show how one gets from here to there. Nevertheless, under a broad range of assumptions regarding the values of these factors and the seriousness of greenhouse-induced climate change, it is likely that there will be a significant demand for nuclear power in the next century provided that the technology and its associated institutions have broad public support.

\subsection{Obstacles to Future Use of Nuclear Power}

Although coal, oil, natural gas, as well as solar sources such as hydropower and biomass all have adverse environmental impacts, no other energy source provokes the same degree of controversy and emotional response as nuclear power. There is considerable literature devoted to this subject, which we do not review here [17]. However, it is 
important to note that nuclear power once enjoyed broad public support in the U.S. and elsewhere, even from many of the environmental groups which now promote solar energy. However, this support has eroded primarily because of: (1) the widespread public concern about the potential for large radioactive releases as a result of accidents at nuclear power plants, especially in the aftermath of the Chernobyl accident, and (2) the perception that the nuclear establishment is not competent to manage what is increasingly viewed as a complex and dangerous technology, and also that it cannot be trusted to tell the truth about the nature of nuclear risks [18].

Besides reactor safety, the nuclear problem of most concern to the general public is the disposal of radioactive waste, particularly high-level wastes [19]. Nuclear terrorism, e.g., theft of nuclear materials or sabotage of nuclear plants, and the diversion of nuclear materials to the production of nuclear weapons (nuclear proliferation) are lesser public concerns.

However, the relative seriousness of these problems is judged quite differently by many prominent anti-nuclear "experts" [20]. From their perspective the problems faced by nuclear power in order of decreasing seriousness are: Nuclear proliferation, nuclear terrorism, reactor safety, and radioactive waste disposal. This perception stems largely from the view that the reactor safety and waste disposal problems are largely amenable to technical fixes, while the proliferation and terrorism problems are not.

Hazard indices based on either maximum permissible radionuclide concentrations or effective dose factors are commonly used to measure the toxicity of radioactive wastes as a function of time. With this assumption, it is also logical to define the time horizon over 
which isolation of waste from the biosphere is required as the period during which the hazard level of the waste is greater than the hazard of the uranium ore originally mined to produce the waste [21]. However, measuring hazard in this manner does not account for possible differences in the availability of various radionuclides once released from the waste package, e.g., to differences in ion exchange rates with the soil through which ground water containing the radionuclides moves. Moreover, unlike uranium ores, high-level waste will be buried at great depths in specially chosen locations with engineered barriers to prevent or reduce releases to the environment. Such considerations would suggest that ore body comparisons overstate the hazard of buried radioactive waste, and provide the basis for the view that the benefit of actinide partitioning and recycle may not be commensurate with the costs associated with the creation of new low and intermediate waste streams arising from the reprocessing and fuel refabrication operations [22] nor with the possible proliferation/terrorism risks associated with large-scale plutonium flows.

The counterargument regarding the benefits of actinide partitioning and recycle is that the hazard of human intrusion into the repository as well as transport of radionuclides from the repository via man-made pathways would be much reduced after several hundred years if the actinide content of the waste is greatly reduced via partitioning and recycle.

Regarding the proliferation problem, the concern of the Carter administration that the spread of nuclear power would lead to a "nuclear-armed crowd" [23] has not materialized; due to a variety of factors, e.g., concerns about reactor safety, slow economic growth, and the high cost of both developing the required infrastructure and building reactors, nuclear power has hardly spread beyond those states which had already 
implemented this technology when President Carter took office. During the last ten years, the focus of proliferation concern has been on the efforts of Pakistan to develop a nuclear weapons capability via unsafeguarded dedicated facilities. However, if concern about greenhouse warming grows, we can expect renewed analyses and debate about the proliferation/terrorism implications of the various passively-safe reactor concepts and their associated fuel cycles [24].

With specific regard to the Integral Fast Reactor (IFR), a key issue in this regard will be how the proliferation/terrorism "resistance' of a nuclear power system consisting of both IFRs and advanced burners (AB), e.g., passively-safe LWRs or modular HTGRs, compares with the resistance of advanced burners operating on once-through fuel cycles. Of course, one could compare IFRs alone to ABs on a once-through cycle. However, the IFR cycle may be too complex for unrestricted deployment worldwide, and even if LWRs are eventually phased out there would be a lengthy transient period during which LWR plutonium would provide start-up cores for IFRs with the LWR wastes also separated into essentially pure fission product and actinide/lanthanide streams by pyroprocessing [25]. Of course, the uranium utilization of a steady state system of IFRs and ABs would not be as good as that of a system of IFRs alone, especially if the IFRs were designed with a breeding ratio $<1$ so as to burn the $\mathrm{AB}$ plutonium, and thus maximize the $\mathrm{AB} / \mathrm{IFR}$ ratio. For example, if the IFRs are designed as plutonium-minor actinide burners (PUMAB) with a breeding ratio of 0.218 , the annual makeup feed for a $450 \mathrm{MWe}$ PUMAB is about $350 \mathrm{~kg}$ of the transuranic mix from an LWR [26]. Since this corresponds to about 1.5 yearly discharges from a $1000 \mathrm{MWe}$ LWR, on an equivalent MWe basis the LWR/PUMAB ratio 
would be about three. The uranium utilization of such a system would be only about $25 \%$ better than that of a system of LWRs alone.

In general, as the breeding ratio of the PUMAB increases, its yearly makeup requirements, and consequently the steady state $A B / P U M A B$ ratio, decreases. For example, the LWR/PUMAB ratio for a PUMAB with a breeding ratio of 0.5 would be about two. Of course, if the IFR were designed as a burner of minor actinides only (MAB), there could be a much larger $\mathrm{AB} / \mathrm{MAB}$ ratio, e.g., an the order of 10 . However, this would raise the issue of what to do with the $\mathrm{AB}$ plutonium; from a proliferation/terrorism perspective recycle of this plutonium as mixed oxide (MOX) fuel in the $\mathrm{ABs}$ would not be acceptable, at least not to those who share the concerns of Williams and Feiveson.

Assuming that $\mathrm{AB}$ plutonium is not separated from minor actinides and rare earth fission products and recycled into the $\mathrm{ABs}$, the key proliferation/terrorism concern associated with the $\mathrm{AB} / \mathrm{IFR}$ fuel cycle is the pyroprocessing operation associated with the IFRs. Although key features of the pyroprocess, e.g., the fact that it takes place in a relatively compact hot cell, are relevant to both its proliferation and terrorism resistance, these concerns must be considered separately if only because the state has a strong interest in preventing the latter, while it would be the agent in the former case.

Besides the state's interest, an additional disincentive to sub-national theft of IFR materials is that plutonium in IFR cycle streams is always associated with minor actinides, fission products and uranium, and thus is unsuitable for direct use in nuclear explosives. In order to produce plutonium some degree of aqueous processing would be required, and this is usually considered to be beyond the abilities of sub-national groups. 
The national or proliferation threat is considerably more difficult to assess. For example, in a non-nuclear weapons state which is a signatory to the Nuclear NonProliferation Treaty (NPT) but nonetheless wishes to obtain nuclear weapons, one would have to compare the technical difficulty of diverting material from the IFR under some assumed safeguards regimen, with either diverting spent fuel from and $A B$ such as an $L W R$, or constructing and operating a wholly clandestine dedicated weapons fuel cycle, taking into account both the probability and the consequences of detection in the three cases. A detailed analysis of this issue is beyond the scope of this paper. However, several points are worth noting:

A key component of the proliferation resistance of the IFR is the ability to detect diversion of plutonium bearing materials from the pyroprocess streams. Given the large flow of plutonium in the IFR, e.g., an equilibrium discharge of about 1500 $\mathrm{kg} / \mathrm{GWe}-\mathrm{yr}[28]$, it will be necessary to use some form of near-real-time materials accounting (NRTA) to detect the abrupt diversion of a significant quantity ( $8 \mathrm{~kg})$ of plutonium [28].

- A particular vulnerability is the plutonium contained in the blanket assemblies, which have a much greater fissile content than those in the core. However, during the period in which IFRs are being used to burn LWR plutonium, no blankets will be used.

- Cell operations are amenable to IAEA inspectors placing and maintaining tamper indicating seals on cell openings and recording cameras within and external to the cell [29]. 
The establishment of a next generation of nuclear power is contingent on the need for installed capacity of nuclear power in the future. The conclusion of this report is that there will almost certainly be a need for substantial nuclear power capacity in the 2000 2030 time frame. A host of energy/electricity demand forecasting models were analyzed ranging from: (1) primary emphasis on energy efficiency to minimize total energy demand, with a greater relative contribution of solar as compared to nuclear on the supply side, to (2) less reliance on efficiency and a much larger nuclear contribution. The models vary on the capacity of nuclear power necessary in the future, ranging from $460 \mathrm{GWe}$ to $2000 \mathrm{GWe}$ worldwide, but each of the models does predict some significant installed capacity of nuclear power in the future.

Nuclear proliferation and nuclear terrorism are significant nuclear power related issues which will come under closer scrutiny when reprocessing schemes, such as actinide partitioning/burning using the Integral Fast Reactor, are included in studies on the future of nuclear power. 


\section{SECTION 3: ASSUMPTIONS FOR SCENARIO DEVELOPMENT}

This section details the assumptions and ground rules which were used to develop the three base scenarios discussed in this report. The final two parts of this section present the reactor types and characteristics, as well as the separation processes assumed for this study.

\subsection{Assumptions and Ground Rules}

\subsubsection{Assumptions}

- It is assumed that all separation and transportation operations will be performed with no material losses.

- It is assumed that all operations take place as hypothesized in the most recent versions of their designs. This includes the LWR, MGR and IFR reactor systems, the pyrometallurgical reprocessing system, the pyrochemical reduction to metal process, and the attendant processes as currently envisioned.

- It is assumed that the advanced light water reactor (LWR) designs are essentially identical to current generation LWR designs from a fuel cycle/high level radioactive waste management standpoint. 
- It is assumed for this analysis that the high-level waste forms developed by the IFR and by the PUREX/TRUEX process will be licensable with the U.S. Nuclear Regulatory Commission and will be acceptable for disposal by the U.S. Department of Energy.

It is assumed for this analysis that the advanced reactor designs utilized in this project will be licensable by the U.S. Nuclear Regulatory Commission for commercial civilian power generation.

- It is assumed that any retrievable spent fuel storage will be accomplished using already licensed metal storage casks.

- It is assumed that the IFR pyrometallurgical reprocessing operation will achieve an actinide separation factor of $99.9 \%(0.999)$. This projected separation level is a factor of 10 better than the currently demonstrated level of $99 \%$. The implications of lower separation factors will be discussed later in the report.

- It is assumed that the PUREX/TRUEX actinide partitioning process will achieve an actinide separation factor of $99.99 \%$. This level has been achieved on a lab scale and can be increased or decreased by increasing or decreasing the number of cascade steps utilized in the process and the number of passes through the cascade. The cost implications of this level of separation will be discussed later in this report. 
- It is assumed that all of these processes can be carried out at a level of safety sufficient to fully protect the workers and the public from occupational hazards and accidents, both ordinary and radiological.

- It is assumed that the fuel used in both types of thermal reactors, the LWR and the MGR, is Uranium Dioxide $\left(\mathrm{UO}_{2}\right)$.

- It is assumed that discharged prismatic MGR graphite fuel blocks (with their fuel sticks completely removed) can be disposed of as Class C Low Level Waste.

- It is assumed that no nuclear material is lost during either the uranium enrichment process of any of the fuel fabrication processes.

- It is assumed that a plentiful supply of natural uranium exists which can be enriched in U-235 for use in thermal reactors (LWR and MGR).

- It is assumed that the clean separation, processing and transportation of elemental plutonium is unacceptable on the grounds of nuclear non-proliferation and the public's non-acceptance of a "plutonium economy." 


\subsubsection{Ground Rules}

- The objective of this project is to determine a set of scenarios for nuclear power development which generate commercial electricity while producing end-point highlevel radioactive wastes which meet the following conditions 500 years after the HLW is generated:

i) all of the end-point high-level radioactive wastes produced must meet the requirements for classification as Class C Low Level Waste as defined by 10 CFR 61 [30].

ii) all of the end-point high-level radioactive waste produced must fall below the radiological risk hazard for unmined uranium ore.

Whereas these limits may be exceeded in times zero to 500 years, they must not be exceeded at time 500 years, nor at any time in the future beyond 500 years. It is recognized that these limits, i) and ii), are not equivalent, and it is recommended that a complete comparison of these two limits be made at a future date, although no such comparison is made in this report.

- Additional baseload electricity generating capacity will be needed in the future.

- Nuclear power will provide some part of this future baseload capacity. 
- In order to be viewed as a serious contender for a significant fraction of this new baseload capacity, new nuclear power plants must meet advanced standards in four critical areas:

1. safety

2. cost

3. waste management

4. proliferation resistance.

- It is assumed that the power plant designers will explicitly address items one and two (safety and cost) in their advanced reactor designs.

- This study will concentrate on items three and four - attempting to form a cohesive high-level waste management system while explicitly maintaining proliferation resistance.

- Proliferation resistance will be explicitly included in the system development and analysis right from the start. Because it is such an important issue, it will not be treated as a secondary add-on item.

- Even if additional nuclear generating capacity is found to be unnecessary, the impetus for this study, an acceptable and sensible approach to high-level radioactive waste management and proliferation resistance, already exists because the spent fuel from 
30 years of LWR operation in the United States has already been generated and is currently situated in over 100 storage sites around the country awaiting a sensible solution to the high-level radioactive waste management debacle.

Only highly developed reactor designs will be considered. These designs must attempt to meet advanced safety and cost goals and should currently be under the auspices of a major development program. The most current available versions of these designs will be used in this analysis.

The nuclear reactor designs which will be used in this analysis are:

1. the current generation LWR (PWR or BWR)

2. the advanced generation LWR (APWR or SBWR); which from the fuel cycle stand point is essentially equivalent to the current generation LWR.

3. the advanced generation MGR (both prismatic fuel and pebble bed)

4. the advanced generation LMR (PRISM).

- Only highly-developed fuel reprocessing designs will be considered. These are designs which either currently exist or could be brought to fruition within the next decade. These designs must attempt to meet advanced safety and cost goals and should currently be the focus of a major development program. The most current available renditions of these designs will be used in this analysis. 
The fuel reprocessing designs which will be used in this analysis are:

1. the PUREX/TRUEX aqueous chemical separation processed under development at ANL

2. the Integral Fast Reactor Pyrometallurgical Reprocessing cycle under development at ANL.

- The process assumed for the reduction to metal of spent LWR and MGR oxide fuel is the pyrochemical process under development at Argonne National Laboratory.

- The PUREX/TRUEX process system design used in this analysis will not be optimized for this application. It is understood that potential changes to this process specifically for this high-level waste management application may prove advantageous, and it is recommended that optimization for this application should be done.

- It is understood that there are other envisioned designs for power reactors, fuel reprocessing and reduction of spent oxide fuel to metal; but the potential processes that were excluded from this analysis are not sufficiently developed or close to commercialization to warrant their inclusion in this analysis, in light of the process requirements outlined above.

- The scenario of LWR with plutonium recycle and MOX fuel fabrication is ruled out ab initio because it violates the goal of inherent proliferation resistance. 
This analysis will deal specifically and solely with civilian nuclear electricity generation, and the high-level radioactive waste generated by civilian nuclear power plants. Defense nuclear power and high-level waste are not treated in this analysis. It is recommended that a similar analysis be performed for defense related HLW.

Another primary objective of this study is to develop scenarios which make use of streams previously considered "waste" streams in conventional thinking - streams such as Depleted Uranium - from Uranium enrichment, and Actinides contained and generated in civilian nuclear power reactor spent fuel. The essence of this objective is to minimize the overall mass and volume of high-level radioactive waste generated by employing the potential symbiotic interplays between reactor systems.

- A concurrent goal is to minimize the mass flows of all waste streams and thereby to limit the total amount of radioactive/hazardous waste requiring disposal.

- This report will concentrate on primary high-level radioactive waste generated within each system - Fission Product Wastes, Actinide Wastes, Hardware and Process Wastes.

- The end-point high-level waste streams are assumed to be emplaced in an underground geologic repository after an interim (ten years or less) cooling time, unless otherwise explicitly stated (e.g. for indefinite period storage to be treated or 
used at some future date).

- It is understood that other means of emplacement are available, however, underground geologic disposal is currently the high-level radioactive waste management strategy chosen explicitly by law (Public Law 97-425 "The High Level Waste Policy Act of 1982" [31]) by the Federal Government of the United States.

- Actinide Wastes can be taken out and stored, or taken out and burned, but fission products must be disposed of in federal underground repositories.

- The end-point high-level radioactive waste streams from each scenario will be left explicitly free-standing for comparative and analytical reasons. It is understood that some of these waste streams would likely be combined and disposed of simultaneously.

- This study will treat low-level waste only peripherally. It is recommended and understood that a full analysis of this subject needs to be done.

- The objective of this study is to achieve these goals for the high-level waste HLW from all civilian nuclear power reactors - IFR and LWR/MGR Thermal Reactors. Therefore, for this study, achieving these goals for one reactor type and not for the other reactor types is not considered a full solution. 


\subsection{Reactor Types Used in Scenario Development}

Three reactor types are considered in this study: the Light Water Reactor (LWR), the Modular Gas-Cooled Reactor (MGR), and the Integral Fast Reactor (IFR). Each of these reactor types is described in brief below.

\subsubsection{The Light Water Reactor (LWR)}

Nuclear reactors are traditionally categorized by their coolant, both primary and secondary, and their moderator. Current Light Water Reactor designs use light water $\left(\mathrm{H}_{2} \mathrm{O}\right)$ as both a coolant and a moderator. The two major types of LWRs, the Pressurized Water Reactor (PWR) and the Boiling Water Reactor (BWR) differ primarily as follows: the PWR has a closed pressurized light water primary coolant circuit which is not meant to boil under ordinary circumstances, coupled to a lower pressure Rankine cycle steam plant via a primary-to-secondary heat exchanger (steam generator); the BWR, on the other hand, uses a direct, single-loop steam cycle in which light water boils in the reactor core to create steam for direct supply to the turbine.

All of the commercial power reactors currently operating in the United States are LWRs utilizing a once-through fuel cycle. Uranium ore is mined, milled, enriched, and processed into fuel assemblies. After burning in the reactor core for either three cycles (PWR) or four cycles (BWR), the now highly radioactive fuel assemblies are discharged 
from the reactor as spent fuel. Currently, the spent LWR fuel assemblies are not reprocessed. They are stored intact on-site to await future disposal in the intact form under current U.S. Department of Energy (USDOE) plans. The intact fuel assemblies are currently the reference high-level radioactive waste form used by the USDOE in waste disposal planning efforts. Typical fuel assembly drawings for a PWR and a BWR are shown in Figures 3-1 and 3-2, respectively [32].

The LWR design attributes used in this report are those of a typical current generation LWR. From a fuel cycle standpoint, the advanced LWR designs appear to be essentially the same as their current generation counterparts. Therefore, for a study in radioactive waste management, the LWR can be taken as essentially standard.

The intact spent fuel assemblies for the two LWR types are very similar. Both use the same production steps, beginning with slightly enriched uranium (approximately 3 to 4 wt\% U-235) in the form of uranium dioxide. The uranium dioxide is formed into cylindrical fuel pellets which are loaded into long zirconium fuel cladding tubes in order to make fuel rods. The Zircaloy cladding protects the ceramic uranium dioxide fuel pellets from direct interaction with the primary coolant water. The fuel rods are bundled into a rectangular array to form a fuel assembly.

After irradiation in the reactor core, the spent fuel assemblies are both thermally hot and highly radioactive. The cylindrical fuel pellets are typically cracked, brittle, and in generally degraded condition, but the Zircaloy cladding usually remains intact and hermetically sealed. The uranium dioxide fuel pellets in the spent fuel now contain a mixture of the original uranium, intermediate mass and relatively short-lived radioactive 


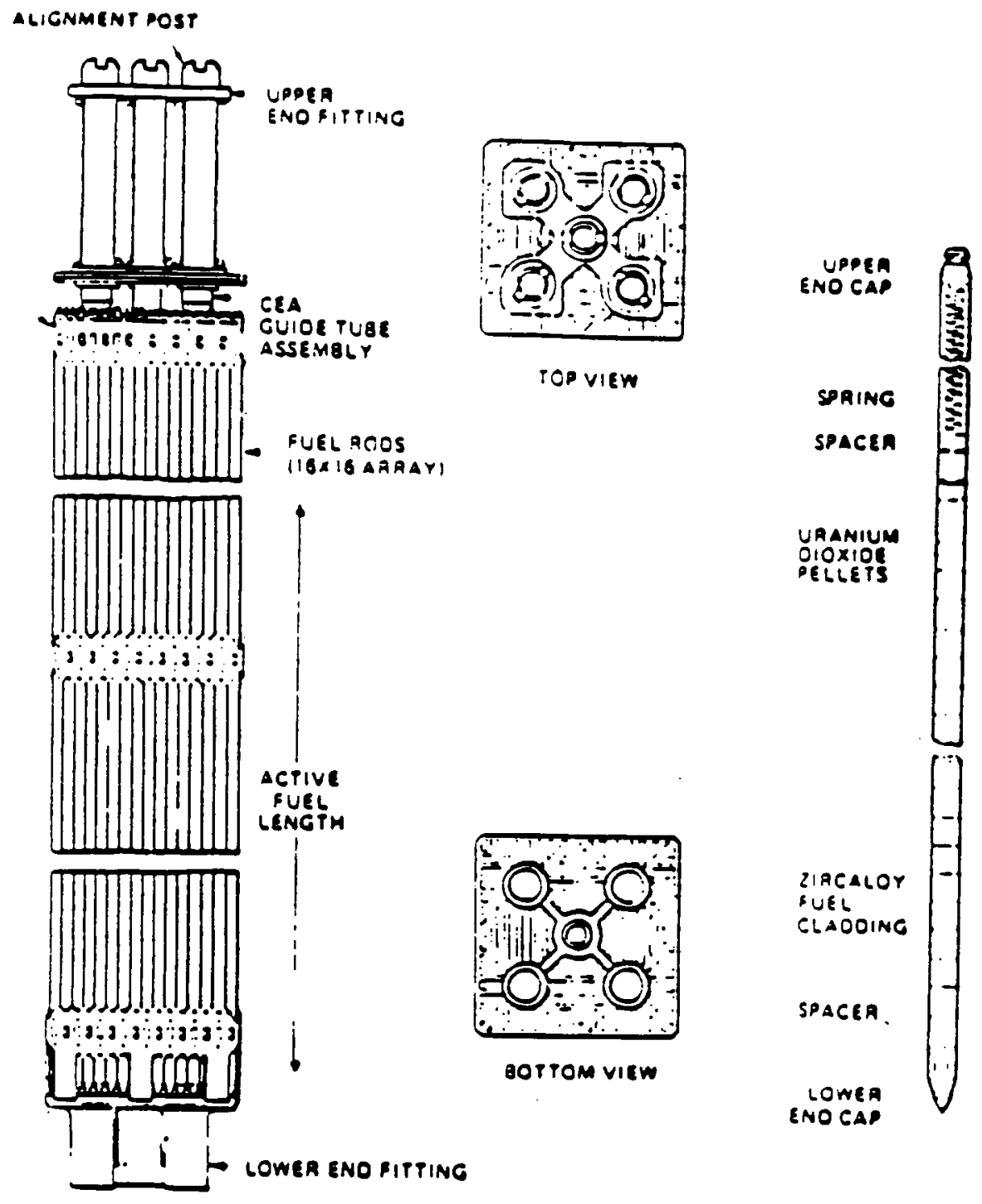

Figure 3-1: Fuel Assembly of a Typical Pressurized Water Reactor [32] 


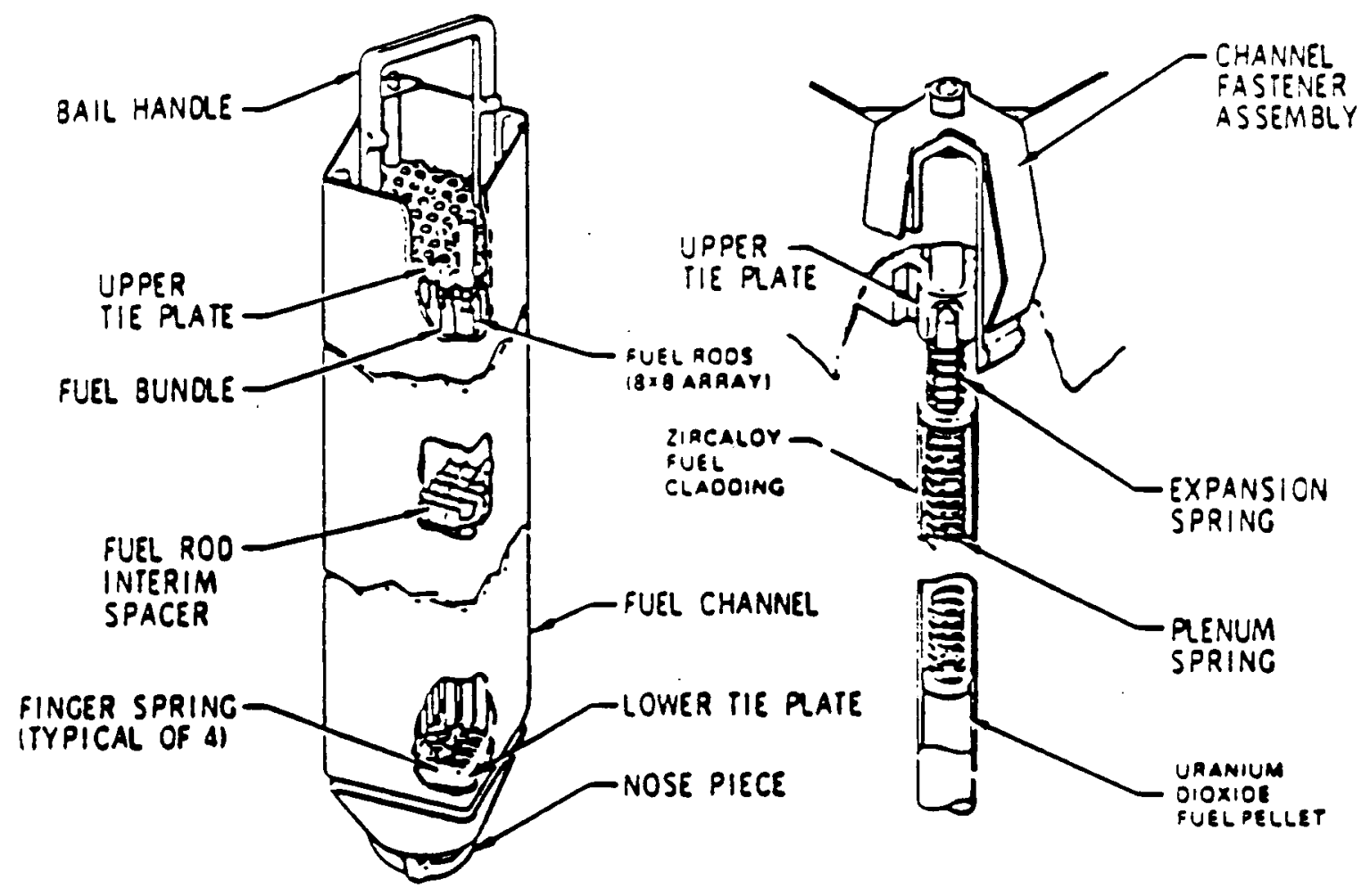

Figure 3-2: Fuel Assembly of a Typical Boiling Water Reactor [32] 
fission products, and heavy long-lived transuranic actinide elements. In addition, some of the fission products, most notably $\mathrm{I}-129, \mathrm{I}-131$, and $\mathrm{Kr}-85$, are in a gaseous state and have been partially released from the ceramic oxide matrix to the open gas plenum located above the fuel pellet stack within the cladding.

Typical characteristics of spent light water reactor fuel assemblies for both PWR and BWR fuel are listed in Table 3-1 [33]. This study will assume an LWR fuel with 33,000 MWD/MTU discharge burnup and a cooling time of two years before reprocessing for consistency with LWR/IFR studies done by Argonne National Laboratory. 
Table 3-1: Characteristics of Light Water Reactor Spent Fuel Assemblies [33]

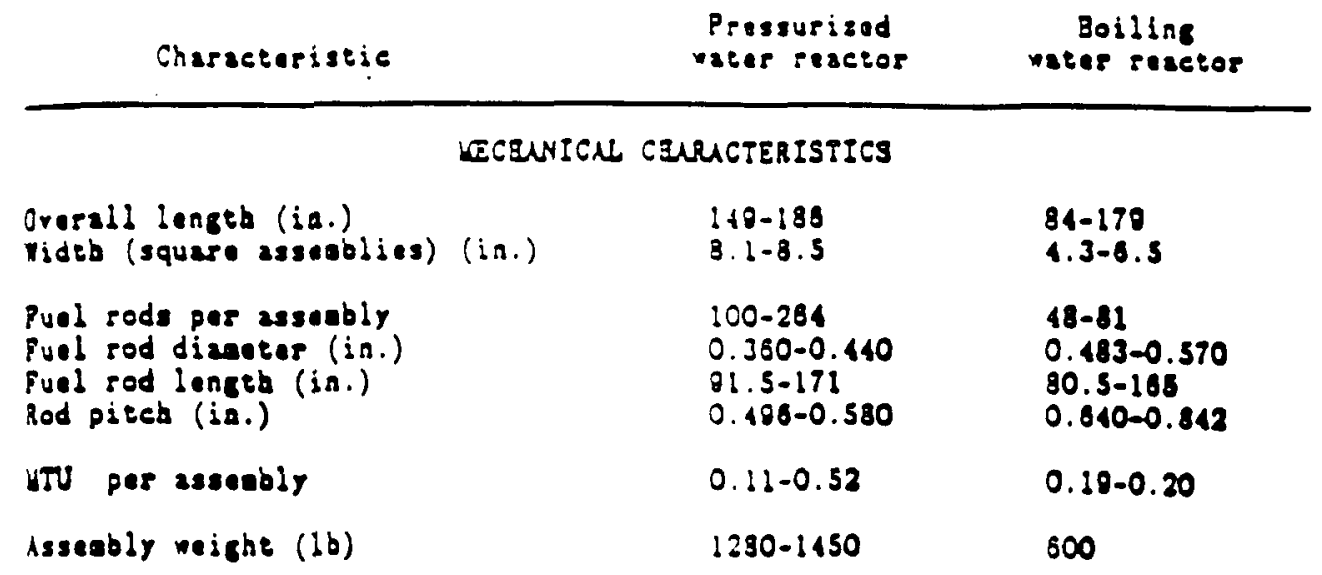

TYPICN GUAUCTERISTICS AS RECEIVED

FIVE-YENR FUEL

\begin{tabular}{|c|c|c|}
\hline Buraup (average conditions) bitd/uTU & 33,000 & 27,500 \\
\hline 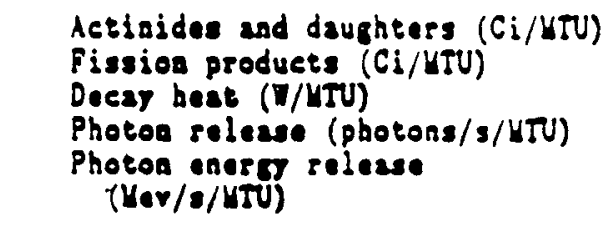 & $\begin{array}{l}104,000 \\
453,000 \\
1,800 \\
1.3 \times 10^{18} \\
4.3 \times 10^{15}\end{array}$ & $\begin{array}{l}93,000 \\
385,000 \\
1,400 \\
1.0 \times 10^{11} \\
3.6 \times 10^{16}\end{array}$ \\
\hline Buraup (bigh coodieloa) WTd/MTU & $50, \infty \infty$ & \\
\hline 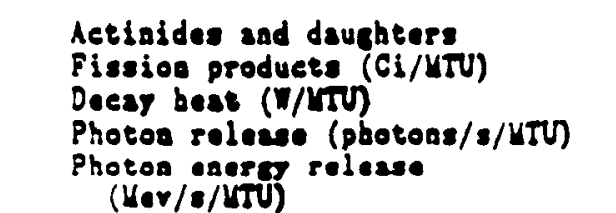 & $\begin{array}{l}153,000 \\
640,000 \\
2,800 \\
1.9 \times 10^{11} \\
7.3 \times 10^{16}\end{array}$ & \\
\hline
\end{tabular}

TEY-REAR FLEL

\begin{tabular}{|c|c|c|}
\hline Buraup (arerace coaditions) & $33, \infty 00$ & $27,5 \infty$ \\
\hline $\begin{array}{l}\text { Actiaidas and daughters (Ci/MTU) } \\
\text { Piesioa producte (Ci/UTU) } \\
\text { Decar beat (W/UTU) }\end{array}$ & $\begin{array}{l}83, \infty 00 \\
302,000 \\
1,100\end{array}$ & $\begin{array}{l}75,000 \\
240,000 \\
000\end{array}$ \\
\hline
\end{tabular}




\subsubsection{The Modular Gas-Cooled Reactor (MGR)}

The Modular Gas-Cooled Reactor (MGR) uses gaseous helium for primary coolant, solid graphite as a neutron moderator, and micro-encapsulated ceramic particle fuel. In traditional designs, the primary system helium coolant is heated in the reactor core and used to generate steam in the secondary steam loop, which is then used to spin the steam turbine in the secondary loop and thereby to generate electricity. In a proposed advanced design, the heated helium which exits the reactor core is used to turn a gas turbine directly and in that way avoids many efficiency robbing conversion steps and complicated steam plant design and operational problems. Beyond that decision, the fundamental design decisions for the MGR focus on selecting a combination of fuel (prismatic or pebble), configuration (side-byside or vertical-in-line), and core configuration (cylindrical, annular, or multi-core).

For implementation in the United States, the U.S. Department of Energy in conjunction with General Atomics selected a $350 \mathrm{MW}_{\mathrm{t}}$ reactor module in a side-by-side configuration using prismatic fuel in an annular core. This reactor type is known as the Prismatic Fuel Modular Gas-Cooled Reactor (MGR-PF). The MGR-PF uses ceramic fuel particles covered with a TRISO coating to retain fission products. The TRISO fuel particle is made up of a low enriched uranium kernel surrounded by a low density graphite buffer region all of which is covered by an inner pyrolytic carbon coating, a silicon carbide shell, and an outer pyrolytic carbon coating. The silicon carbide coating acts like a tiny pressure vessel to retain the fission products produced within the particle. The performance characteristics of these TRISO particles are such that there is on the order of only one 
particle failure out of every 100,000 particles. The coated TRISO particles are intimately blended and bonded together by a carbonaceous binder into fuel compacts. The fuel compacts are in the shape of "fuel sticks" which fit into the fuel holes drilled into the prismatic graphite moderator blocks. The completed blocks (with fuel compacts inserted) form the MGR-PF fuel assemblies. This operation is illustrated in Figure 3-3 [34]. The makeup of the three-layer TRISO fuel particle, clearly illustrating the location of the silicon carbide "pressure vessel," is shown in Figures 3-4 and 3-5 [35]. The graphite fuel elements are right hexagonal prisms of the same size and shape as those used in the Fort St. Vrain HTGR power plant. A standard Fort St. Vrain fuel assembly is shown in Figure 3-6 [36]. Average burnup of MGR-PF fuel is projected to be $82,460 \mathrm{MWD} / \mathrm{MTHM}$ [37]. The current design projections call for fissile fuel particles to be made up of a two-phase mixture of $19.8 \% \mathrm{U}-235$ enriched $\mathrm{UO}_{2}$ and $\mathrm{UC}_{2}$, usually referred to as $\mathrm{UCO}$ [34]. The fertile fuel may be either thorium dioxide $\left(\mathrm{ThO}_{2}\right)$ or depleted $\mathrm{UO}_{2}$.

For implementation in the Federal Republic of Germany (FRG), designers selected a pebble bed cylindrical core using a side-by-side reactor configuration. This helium-cooled, graphite moderated reactor uses spherical ceramic fuel balls, or fuel pebbles. For this reason, this class of reactor is generically known as the Pebble-Bed Modular Gas-Cooled Reactor (MGR-PB). The MGR-PB fuel pebbles consist of a packed core of low enriched uranium dioxide TRISO fuel particles packed in a carbonaceous matrix, and covered with a graphite shell. The entire fuel pebble is approximately 6 centimeters in diameter. An MGR-PB spherical fuel pebble is shown in Figure 3-7 [38]. The MGR-PB fuel is projected to have a fuel enrichment of $7.7 \mathrm{wt} \%$ uranium-235 [38]. The average expected burnup of 


\section{FUEL PARTICLES}

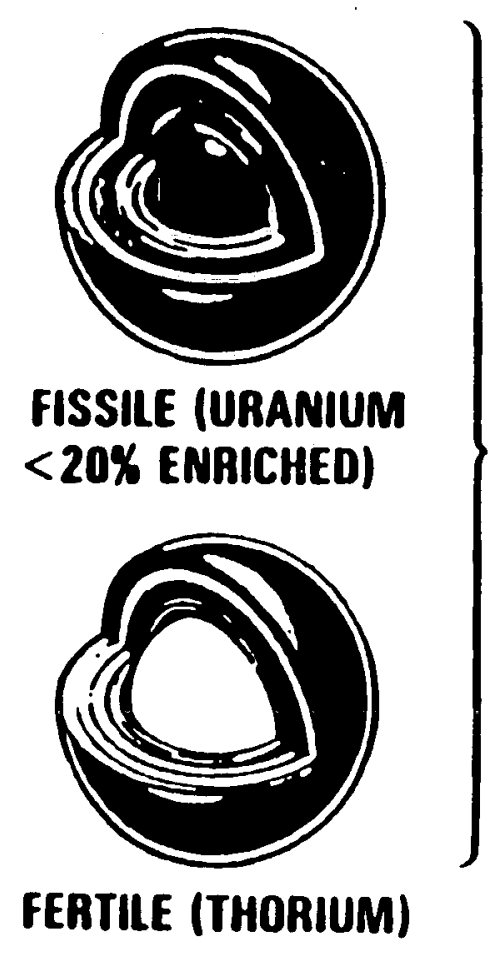

PRISMATIC

FUEL ELEMENT

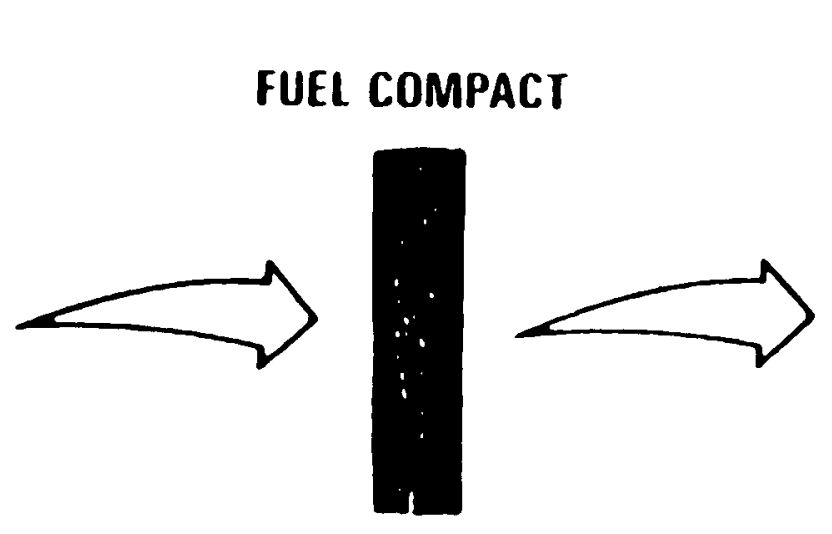

Figure 3-3: MGR Prismatic Fuel Element Components [34] 


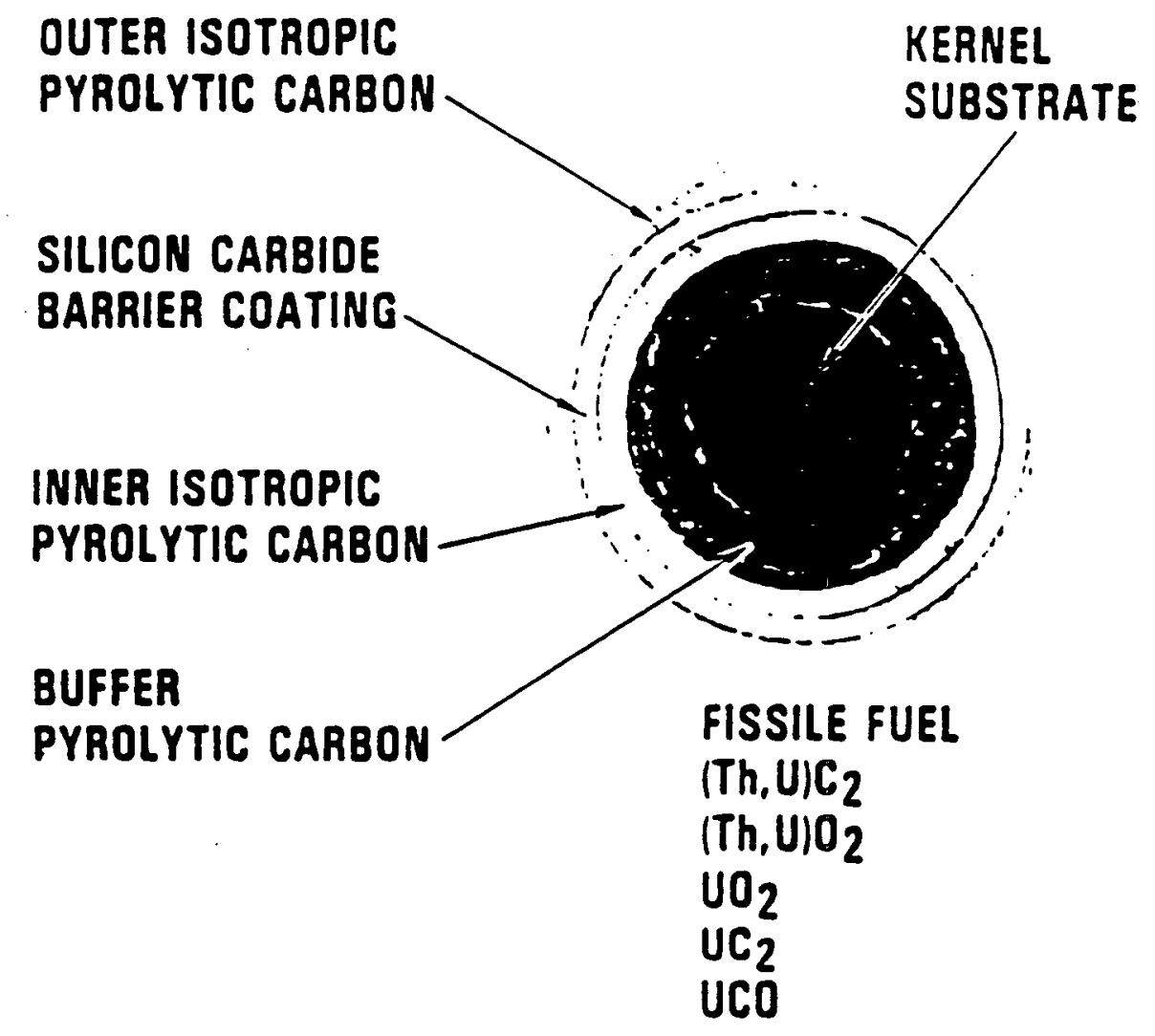

Figure 3-4: Ceramographic Cross Section of HTGR Coated Fuel Particle [35] 


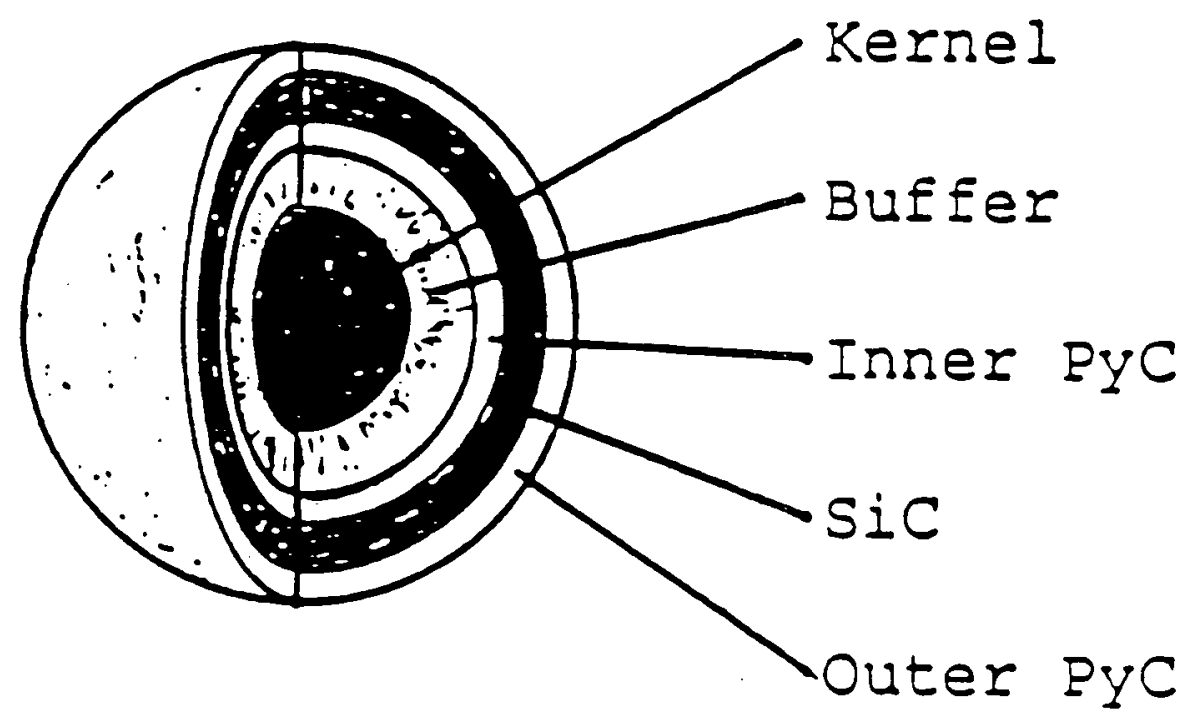

Figure 3-5: The TRISO Fuel Particle Design [35] 


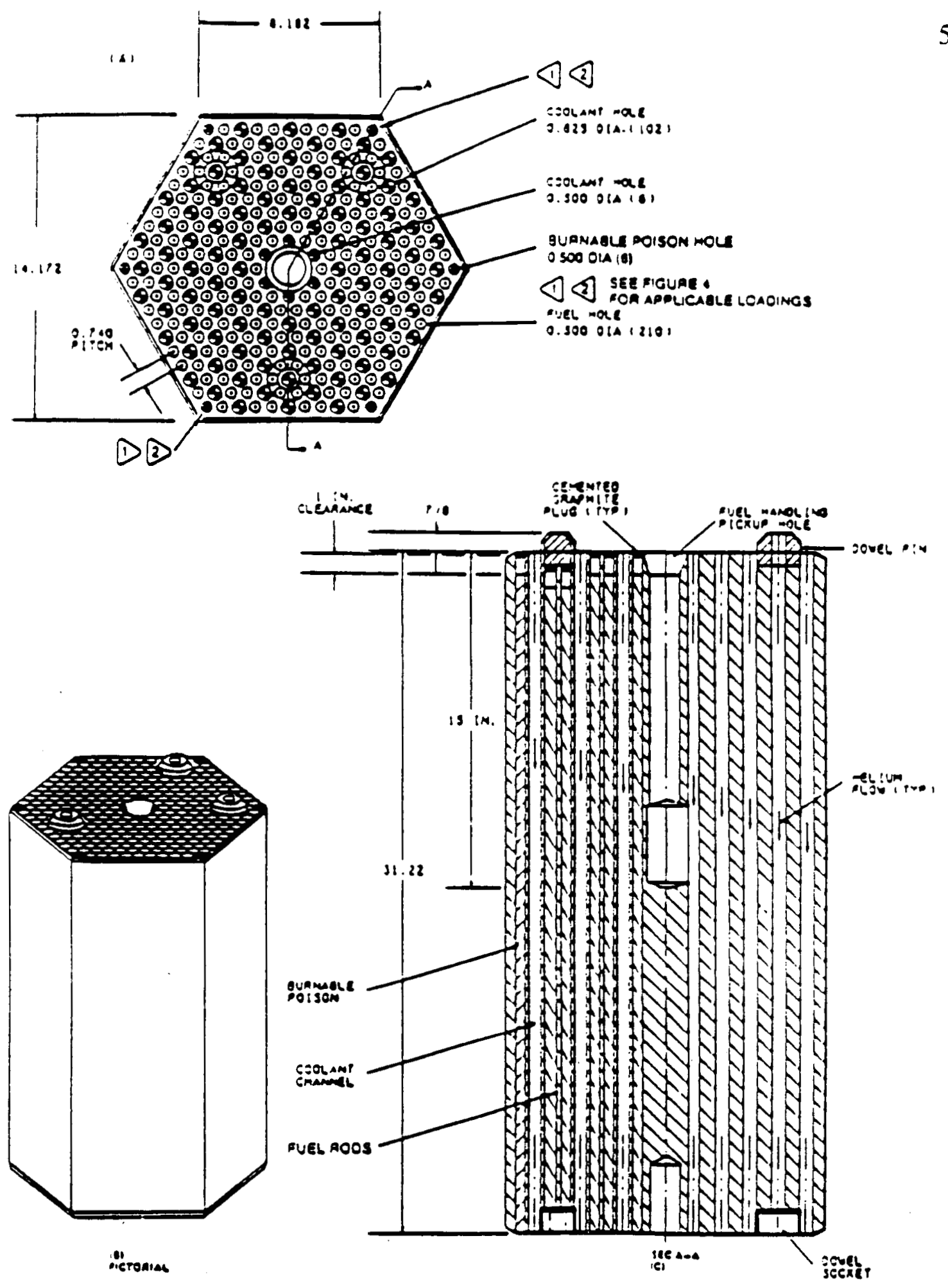

Figure 3-6: Fort St. Vrain Standard Fuel Element [36] 

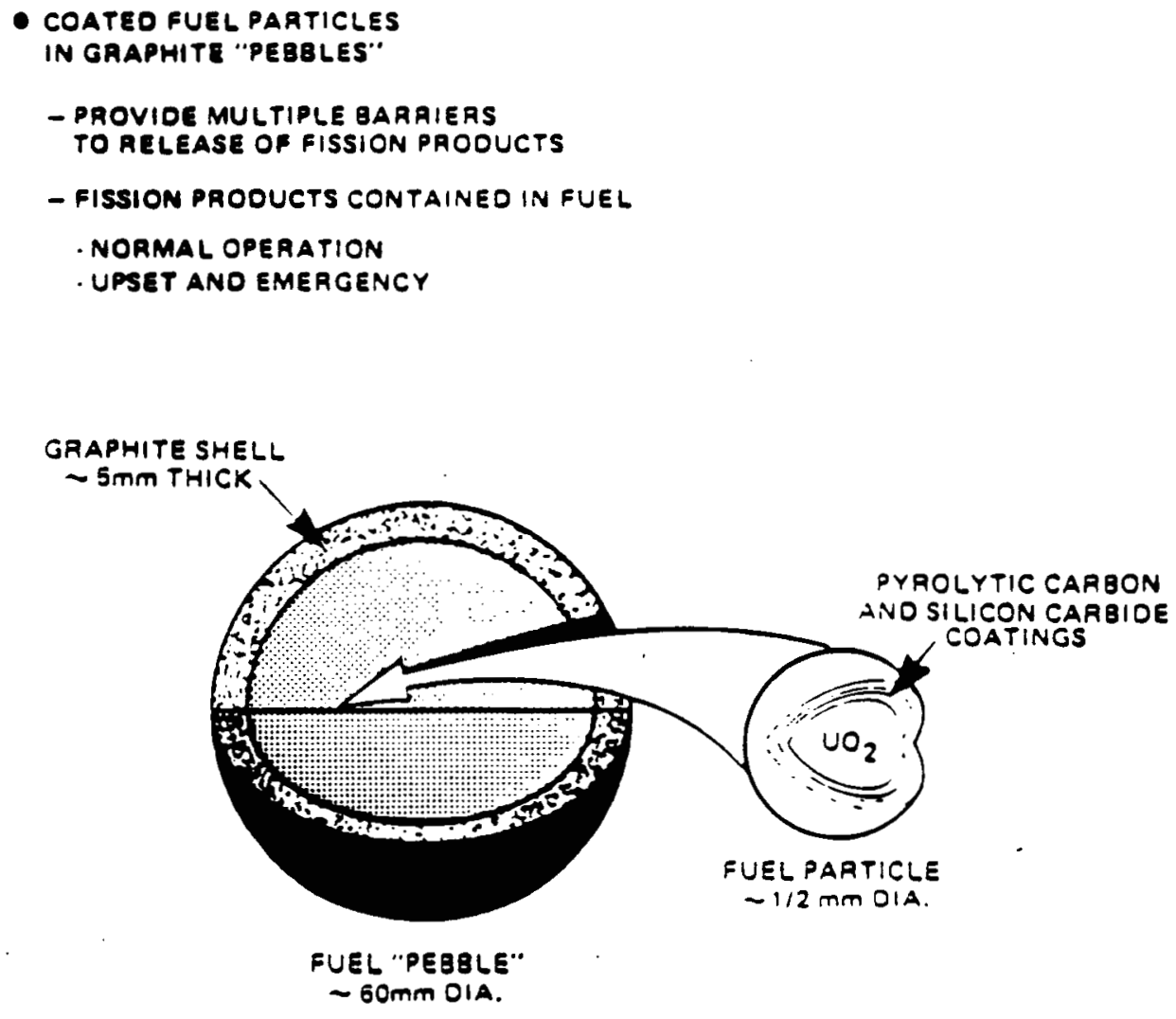

Figure 3-7: Pebble Bed MGR Spherical Fuel Element [38] 
the fuel pebbles is 1006.8 full power days at an average element power of $0.56 \mathrm{Kw}$ for each 7 gram fuel pebble [38]. This translates into a burnup of 80,544 MWD/MTHM.

The principal design of the MGR-PB type reactor is the Interatom/KWU Modular HTGR concept developed in the FRG under the HTR-Module designation [39], and in the United States as a reactor design study done for a consortium of companies [38]. Important design and performance characteristics of this plant are given in Tables 3-2 and 3-3 [38]. 
Table 3-2: Pebble Bed MGR Plant Design and Performance Parameters [38]

$$
\text { PLANT DESIGN AND PEREORMANCE PARAMEIERS }
$$

\section{PLANT}

$$
\text { Arrangement }
$$

Thermal Rating

Electrical Rating

Net Efflcleacy

REACTOR MODULE

Conf1guration

Thermal Power

Fuel

Enrichment

Hellum Inlet Temperature

Hellum Ourler Teaperature

TURBINE CYCLE

Feedwater Flowtate

Feedwater Temperature

Feedwater Pressure

Steam Temperature

Steax Pressure

Turblae Rat108

Iurbine Heat Rating

Condenser Backpressure
Four Reactor Modules;

Two Turblae Generator Sets

$800 \mathrm{MW}$

$320 \mathrm{MW}$ (G50s8)

$298 \mathrm{IN}$ (Net)

37.27

S1de-By-S1de

$200 \mathrm{MH}$

$360,000,6 \mathrm{~cm}$ Pebbles

7 go Heavy Metal/Pebble

$0.54 \mathrm{gm} U-235$

$6.46 \mathrm{gm} \mathrm{U-238}$

$250^{\circ} \mathrm{C}$

$700^{\circ} \mathrm{C}$

$77.2 \mathrm{~kg} / \mathrm{sec}$

$180^{\circ} \mathrm{C}$

210 Bar

$530^{\circ} \mathrm{C}$

$210 \mathrm{Bar}$

200 MVA

$9155 \mathrm{Btu} / \mathrm{khh}$

2.22 inches $\mathrm{H}_{2} \mathrm{O}$ 
Table 3-3: Pebble Bed MGR Principal Reactor Core Data [38]

$$
\text { PRINCIPAL REACTOR CORE DATA }
$$

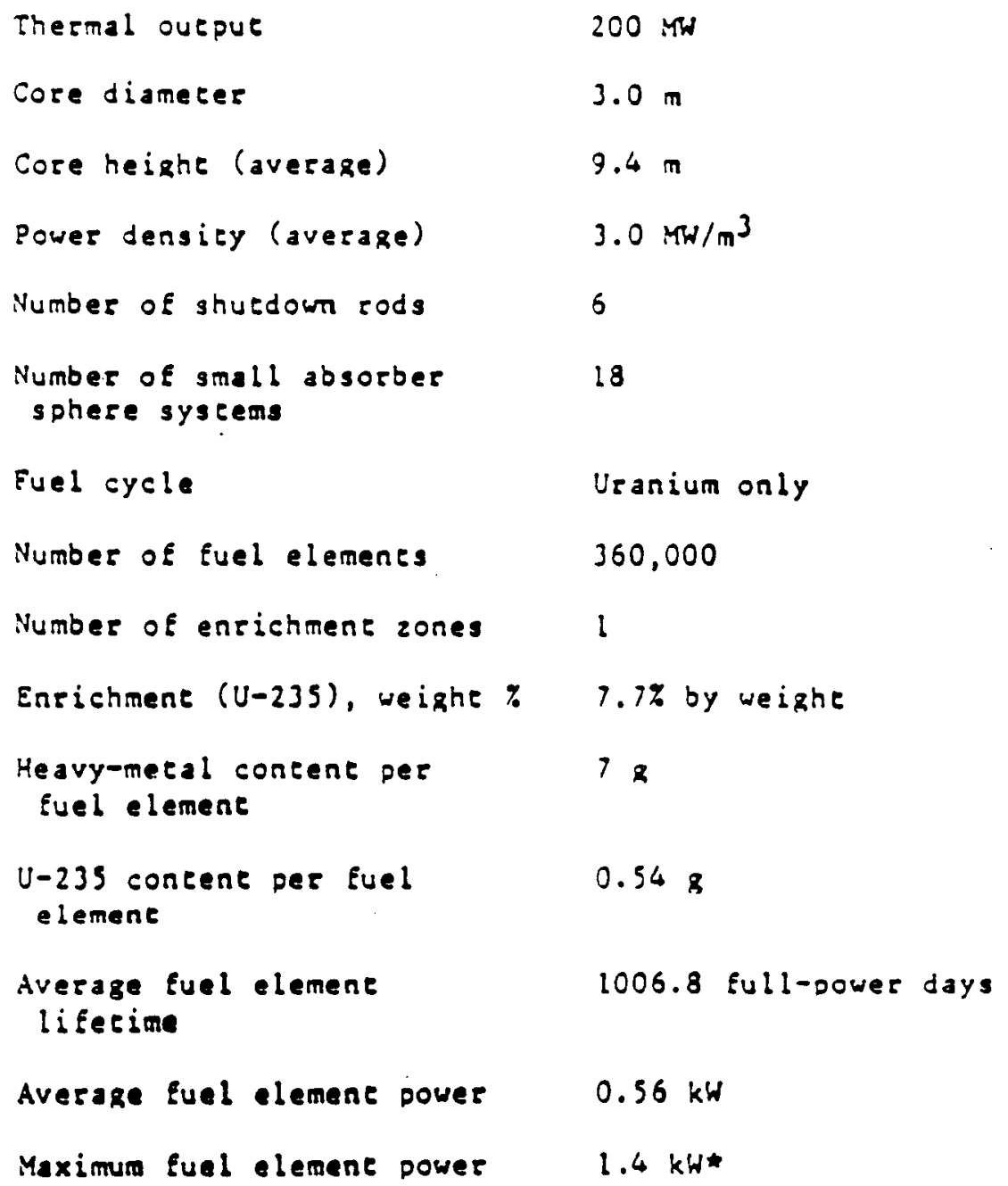

* Fresh fuel element in the equilibrium core 


\subsubsection{The Integral Fast Reactor (IFR)}

The Integral Fast Reactor (IFR) is a generic concept based on four major technical features: (1) liquid sodium cooling, (2) pool-type reactor configuration, (3) metallic fuel, and (4) an integral fuel cycle. The IFR fuel cycle is based on pyrometallurgical fuel reprocessing and metallic fuel fabrication performed at a fuel cycle facility co-located with the reactor. The IFR reactor fuel is a metallic alloy of uranium, plutonium, and zirconium with small amounts of other actinide elements carried over from the reprocessing operation. Metallic fuel provides the IFR liquid metal cooled fast reactor with the highly desirable property of high thermal conductivity. Typical design parameters for the metallic fuel are given in Table 3-4 [40]. The metallic fuel is injection cast into fuel pins which are inserted into fuel cladding tubes and thermally bonded to the cladding tubes by a thin layer of sodium. This fuel is capable of achieving extremely high peak discharge burnups, on the order of 150 MWD/kg versus $45 \mathrm{MWD} / \mathrm{kg}$ for LWR fuel. Average IFR fuel burnup is projected to be 92,000 MWD/MTHM [41].

After the IFR fuel is discharged from the reactor, it is to be reprocessed to recover the actinide elements, as much as is economically and technically feasible, which are to be used as input to the next batch of metallic fuel pins. The IFR is designed to act as an actinide burner and as a means to get rid of the long-lived actinide elements from its highlevel waste. The reprocessing operations are to be performed at an on-site reprocessing facility which will contain all of the equipment necessary to recycle spent fuel assemblies, recover the uranium, plutonium, and other actinides from the fuel assemblies, and to 
Table 3-4: Typical Metal Core Design Parameters [40]

\begin{tabular}{|l|l|}
\hline Euel Materials & U-Pu- $10 \% \mathrm{Zr}, \mathrm{U}-10 \% \mathrm{Zr}$ \\
Euel Smear Density & $75 \%$ \\
Pin Diameter & $7.6 \mathrm{~mm}(0.3 \mathrm{in.})$ \\
Cladding Thickness & $0.46 \mathrm{~mm}(0.018 \mathrm{in.})$ \\
Peak Linear Power & $50 \mathrm{~kW} / \mathrm{m}(15 \mathrm{~kW} / \mathrm{ft})$ \\
Peak Discharge Burnup & $150 \mathrm{mWd} / \mathrm{kg}$ \\
\hline
\end{tabular}


manufacture new assemblies. The sequence of processes to be carried out to realize these objectives is shown in Figure 3-8 [42].

After being removed from the core, the spent IFR fuel assembly is to be moved to a holding tank in the reactor building where it will be allowed to cool for a year. After a year, the fuel assembly is to be moved to the on-site fuel reprocessing facility. Once in the facility, the assembly hardware will be removed and treated as an intermediate level waste. The gas plenum sections of the fuel rods are then to be removed and to be included as part of the high-level radioactive waste. When the plenum sections are removed, all unconfined fission gases will be released into the cell atmosphere. These fission gases are to be collected and retained in gas cylinders. The fuel elements will then be chopped or shredded and placed in anode baskets for electrorefining. Driver fuel assemblies and blanket fuel assemblies (if used) are to be handled in a similar manner, but will be routed to separate furnaces for electrorefining.

In the electrorefining furnace, the anode basket will be lowered into an electrolyte of barium, cadmium, and lithium chlorides which will float above a pool of liquid cadmium. The electrical potential set up between the anode and the cathode will cause the heavy metal ions in the anode to collect on the cathode in a multi-crystalline configuration. By varying the electrical potential between the cathode and the anode, the process will be able to remove virtually all of the heavy metal actinide ions from the anode and deposit them either on the cathode or in the electrolyte salt. The majority of the fission products are dissolved in the chloride salt, while the noble metal fission products will fall into the liquid cadmium pool. Some of the rare earth fission products will follow the actinide elements to 


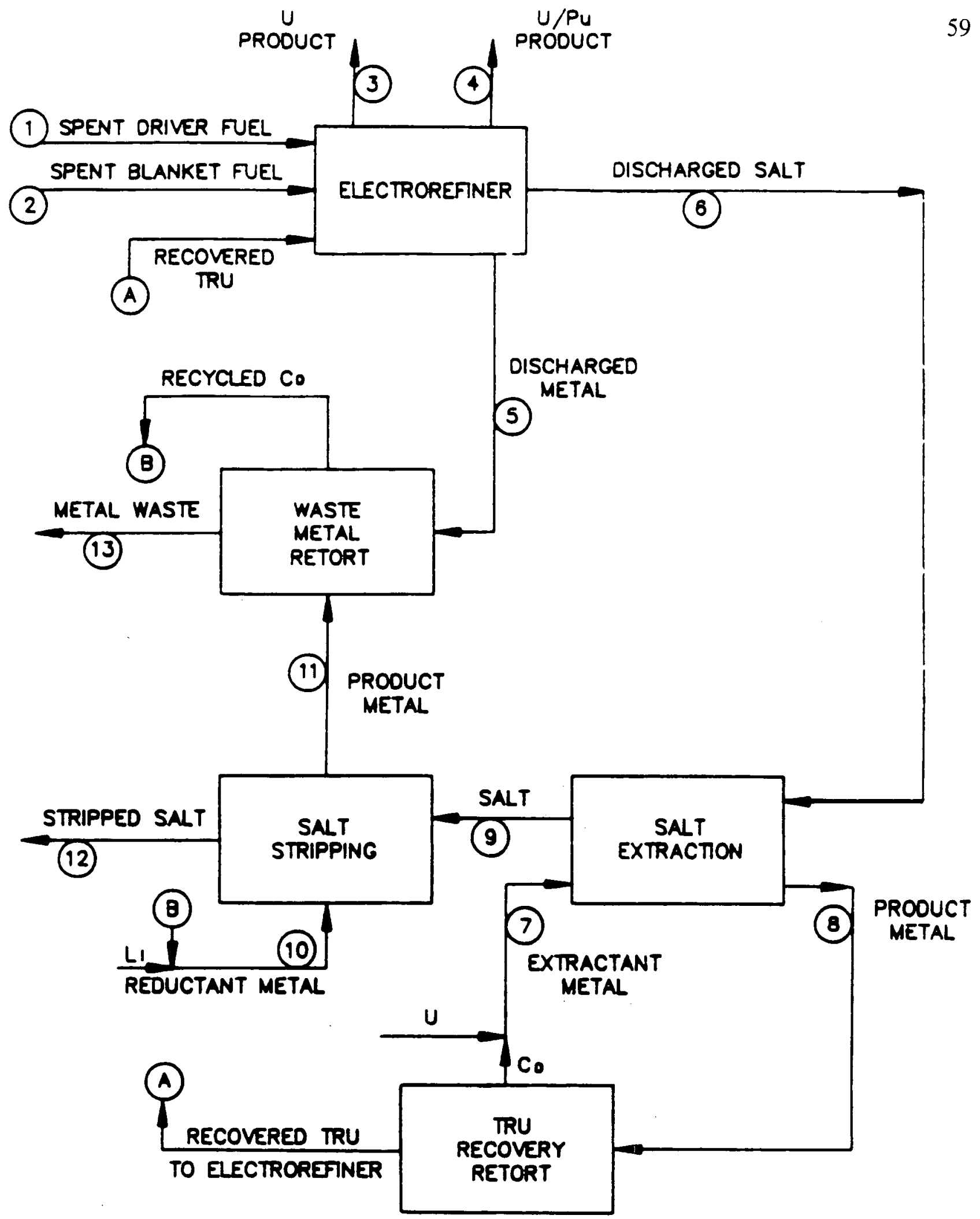

Figure 3-8: Pyrochemical Electrorefining Process for IFR Fuels [42] 
the positive cathode. The heavy metal actinide ions crystallized on the cathode are to be sent to a pin casting device where the metal will be melted, mixed to the appropriate effective enrichment and alloy composition (with additional uranium added as needed), and injection cast into a pin mold to create new fuel rods. The injection casting of the metallic fuel pins will provide a major advantage compared to ceramic oxide fuel fabrication because it will be simple to recycle damaged or out of specification fuel by simply remelting and recasting the defective metal pin.

The electrorefiner salt is to be periodically partially replaced to prevent a buildup of impurities such as fission products and actinides which could affect the efficiency of the electrorefining process. The skimmed electrorefiner salt will be sent, along with the cladding hulls, electrorefiner metal waste, and process ceramic waste such as pin molds, anode blankets and crucibles, to the IFR high-level waste treatment process represented in Figure 3-9 [43]. The skimmed electrorefiner salt is to be first treated by a reducing process using cadmium and lithium to extract virtually all the actinides contained in the salt. The resulting waste stream is projected to contain less than $150 \mathrm{nCi} / \mathrm{g}$ of alpha emitting isotopes [42]. The lithium will act as a strong reducing agent because it forms a strong chloride. As a result, it will be very simple to separate the actinides from the salt wastes. These actinides are to be returned to the pin casting step where they will be mixed in with the uranium and plutonium and returned to the reactor to be burned as an integral part of the process. Once the actinides have been extracted, the electrorefiner salt will be left with essentially all of the high-activity, short-lived fission products, dominated by such radionuclides as strontium-90 and cesium-135. This salt waste is to be immobilized in some type of matrix yet to be 

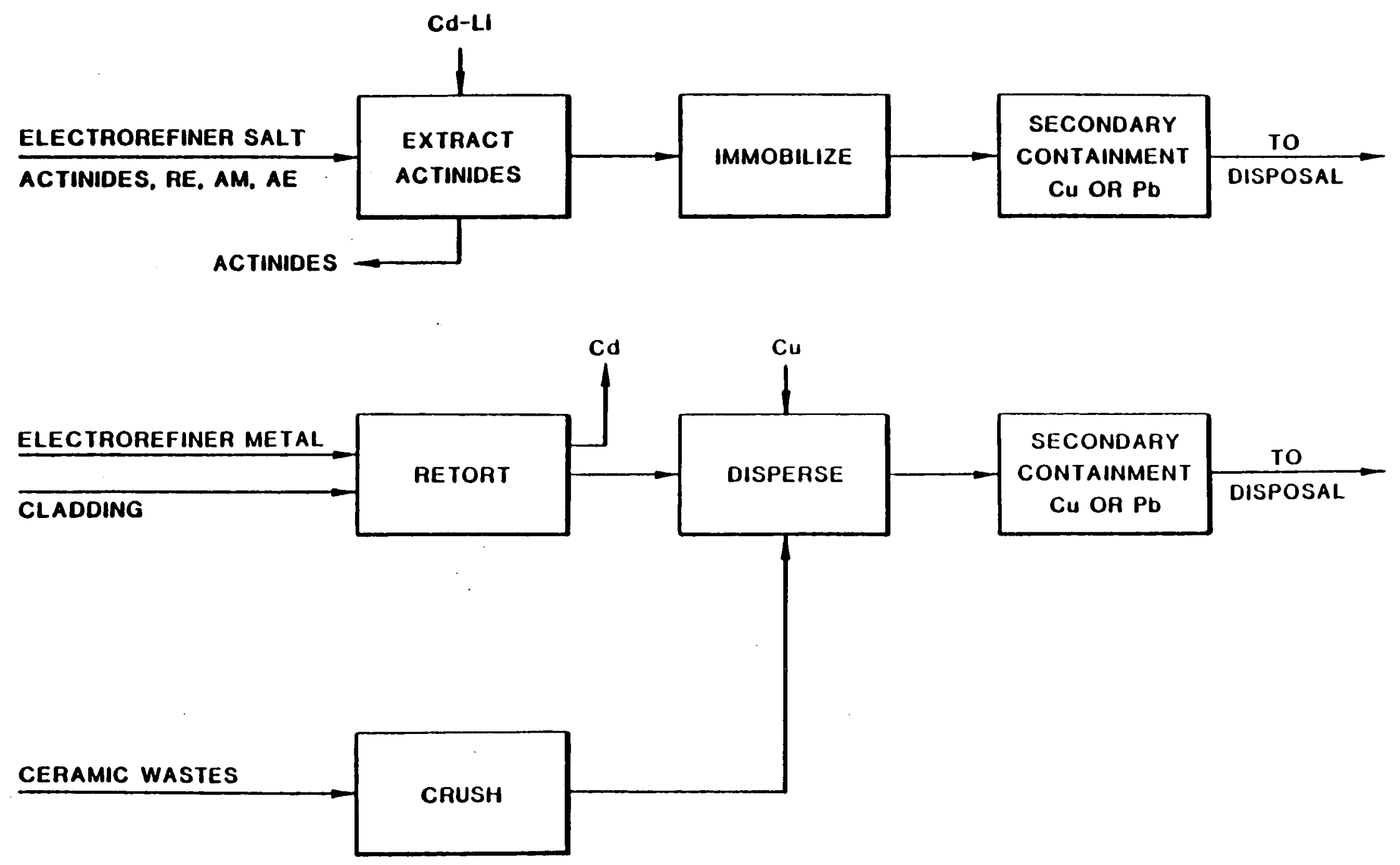

Figure 3-9: IFR High-Level Waste Flowsheet [43] 
decided on, ranging from an inexpensive mortar matrix to an expensive copper matrix.

The second waste stream will have as initial input the cladding hulls from the fuel element reprocessing operation which will be contaminated with some fission products and some residual actinide elements that may remain in the cladding during the fuel removal process, and some of the electrorefiner metal which is to be periodically skimmed from the cadmium anode. In light of the potential for new regulations which would either limit or prohibit the disposal of substantial quantities of the highly toxic element cadmium, the waste stream will first go through a retort process which will remove the cadmium metal from the mixture of fission products, actinides, and cladding hulls. The retorted cadmium is to be returned to the reprocessing operation for use in the electrorefining step. While this step is taking place, the actinide contaminated ceramic wastes from the fuel reprocessing operation, including crucibles, anode baskets, and fuel pin molds, will be crushed to a particle size on the order of the cladding hulls (one-half inch) [42]. These two waste streams will then be mixed together and dispersed in a copper matrix. The resulting waste form made up of cladding hulls, ceramic wastes, fission products and actinides in a copper matrix will be a high-level waste in the traditional sense having both short-lived and some long-lived radionuclides. This copper ingot waste form, as well as the salt waste matrix waste form discussed earlier, is to be placed into an overpack canister made of either copper, stainless steel, or a high-performance metal alloy. 


\subsection{Separation Processes Used in Scenario Development}

Fuel discharged from a reactor after irradiation to the end of its useful life still contains most of the fertile material (U-238) that was present in the fuel when it was charged to the reactor, and also contains appreciable concentrations of potentially valuable fissile nuclides (primarily U-235 and Pu-239) in addition to a significant quantity of highly radioactive, thermally hot fission products. A variety of methods have been proposed for separating out the useful fuel materials in the spent nuclear fuel from the chain-reaction ending poisonous fission products. The two most successful methods developed to date are separation and extraction by aqueous chemical processes, the PUREX and the TRUEX processes, and separation and extraction by the pyrometallurgical process developed for the Integral Fast Reactor (IFR) fuel cycle. In addition to these processes, means for spent fuel preprocessing, a method of changing the used nuclear fuel into a form which can be fed into the separation processes, must be developed.

These mechanisms for separating and extracting the useful constituents the of spent nuclear fuel from the materials which are truly waste is known as reprocessing. The principal objectives of reprocessing are listed below:

(1) to recover uranium and plutonium for reuse as nuclear reactor fuel.

(2) to remove radioactive and neutron-absorbing fission products from the spent nuclear fuel.

(3) to convert the radioactive constituents of spent fuel into forms suitable for safe, long-term storage. 
(4) to recover some individual fission products such as Sr-90 and Cs-137 for use as radiation sources.

(5) to recover by-product minor transuranic (TRU) elements like neptunium, americium, and curium for possible reuse as nuclear reactor fuel and to reduce the long-lived hazard of the high-level waste.

The processes assumed applicable for the purposes of this study for spent fuel preprocessing, aqueous chemical reprocessing, and pyroprocess reprocessing are presented in the following sections.

\subsubsection{Thermal Reactor Spent Fuel Preprocessing}

The methods of thermal reactor spent fuel preprocessing used in this study are presented below. Due to the distinct differences between Light Water Reactor (LWR) fuel and Modular Gas-Cooled Reactor (MGR) fuel, a distinct spent fuel preprocessing method is developed for each of the two fuel types.

\subsubsection{Light Water Reactor Spent Fuel Preprocessing}

The process for LWR spent fuel preprocessing is shown in the schematic Figure 3-10. The major operations of the process are described below. 


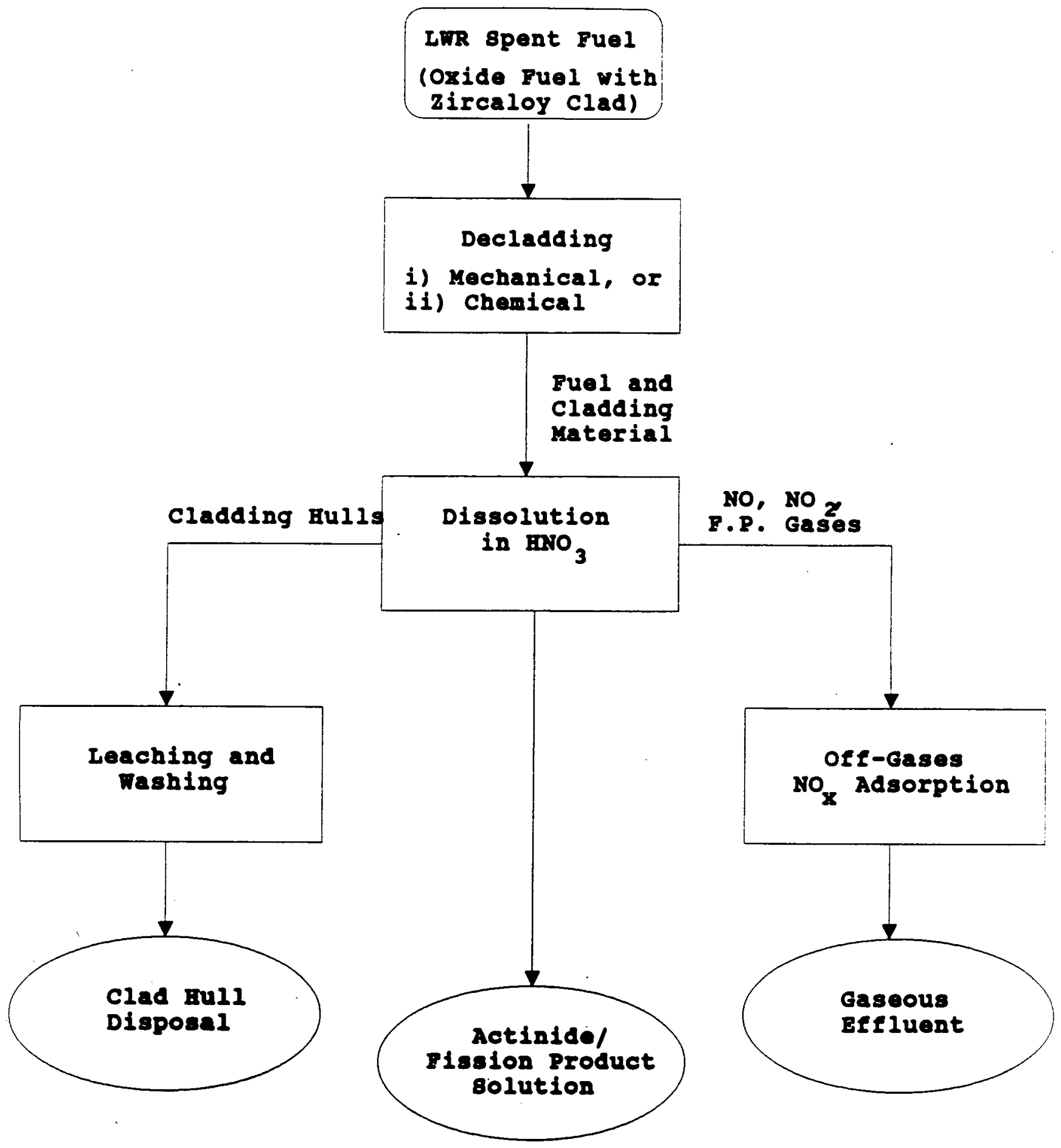

Figure 3-10: LWR Spent Fuel Preprocessing 
After removal from the reactor, the spent LWR fuel is cooled for a period of two years. The first step in the preprocessing operation is to remove the zirconium-alloy cladding from the stack of oxide fuel pellets. This decladding operation can be performed in one of two ways: mechanical decladding, or chemical decladding.

\section{Mechanical Decladding:}

The object is to break or cut the cladding so as to expose the fuel to reaction with dissolvent during the next step in the process. Methods that have been demonstrated to date include transverse chopping with a shear, transverse cutting with a saw or abrasion wheel, longitudinal slitting, and longitudinal extrusion $[44,45]$.

Chemical Decladding:

The object is to dissolve the cladding and thereby to leave the fuel as a separable solid. Chemical decladding has the disadvantage that the clad reaction products require more storage space than the original cladding. There have been different process developed for chemical decladding such as the ZIRFLEX process [46], the SULFEX process [47], and Electrolytic Dissolution [48].

Following the decladding step, the spent oxide fuel pellets are either dissolved in a bath of Nitric acid at which point the mixture can be sent to the PUREX process for aqueous reprocessing, or are left as intact oxide fuel pellets for feed to the pyrochemical reduction to metal process. The resulting waste products include the cladding hulls from 
mechanical decladding, which are washed and leached, and the off-gas production from the fuel dissolution process, which is contained via $\mathrm{NO}_{\mathrm{x}}$ absorption.

\subsubsection{Modular Gas-Cooled Reactor Spent Fuel Preprocessing}

The process for MGR spent fuel preprocessing is shown in Figure 3-11.

After removal from the reactor, the spent MGR fuel is cooled for a period of several years. The first step of the preprocessing operation is to crush the graphite matrix (which contains the spent fuel) into pieces on the order of one inch in diameter [49]. These pieces are fed to a fluidized combustion furnace where the graphite is transformed first into Carbon Dioxide $\left(\mathrm{CO}_{2}\right)$, and then, via contact with $\mathrm{Ca}(\mathrm{OH})_{2}$, into Calcium Carbonate $\left(\mathrm{CaCO}_{3}\right)$. The Carbon Dioxide is not vented to the atmosphere because of contamination due to Carbon-14 present in the graphite matrix as a result of neutron absorption in Nitrogen-13 impurities $[50,51,52]$. An alternative process to bulk burning of the graphite matrix of prismatic MGR fuel may be to remove the "fuel sticks" from the non-fueled graphite block, and then to process the much smaller mass of the spent "fuel sticks" using the process outlined above.

The Silicon Carbide ( $\mathrm{SiC}$ ) coated fuel particles remain intact throughout the $950^{\circ} \mathrm{C}$ burning process $[53,54]$. These fuel particles are crushed in a press to break their outer SiC coating [49]. At this point the $\mathrm{SiC}$ and the remaining graphite are separated from the spent fuel fission products and actinides by taking advantage of the density differences and floating off the $\mathrm{SiC}$ and the graphite. 


\section{MGR 8pent Fuel Preprocessing}

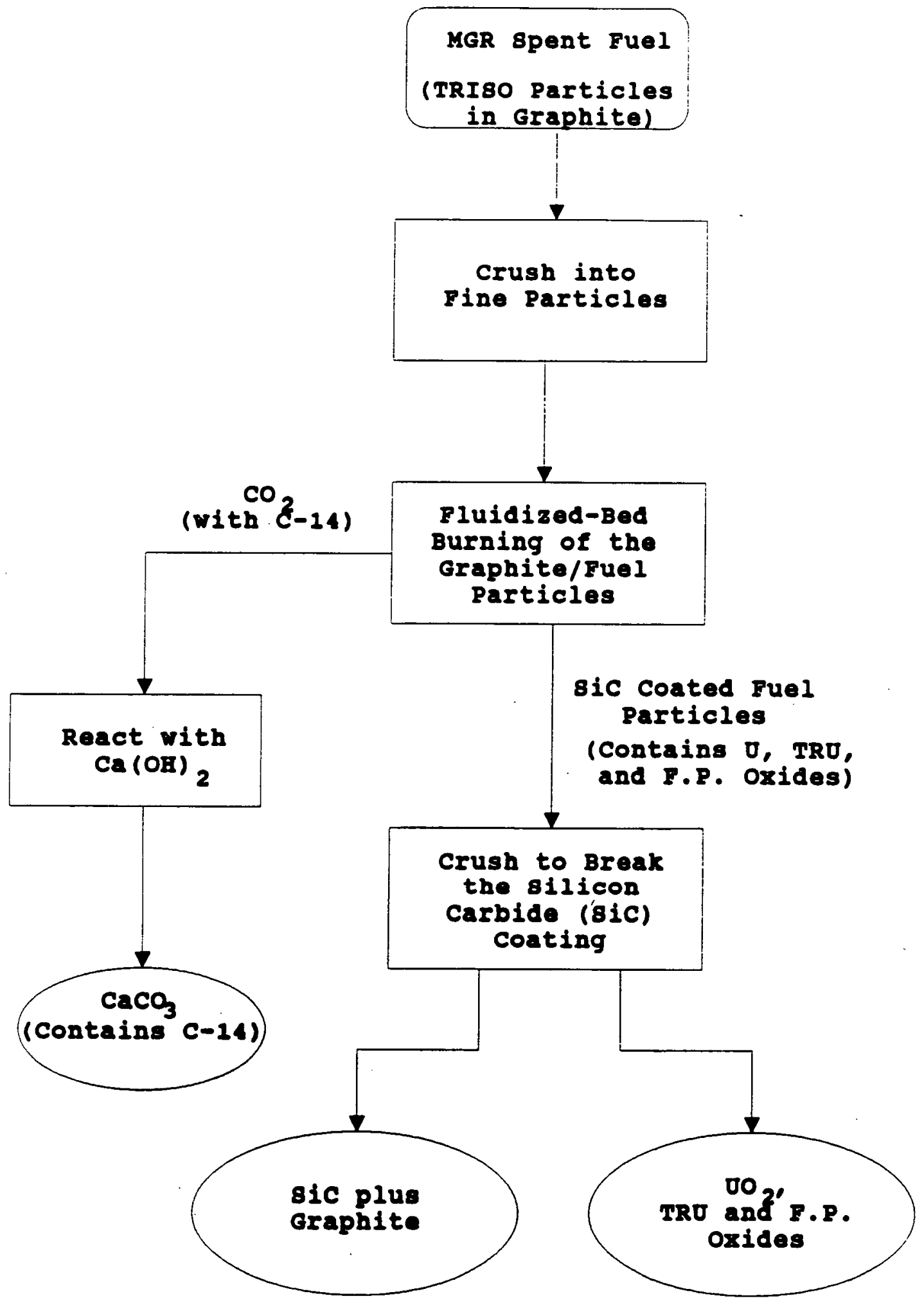

Figure 3-11: MGR Spent Fuel Preprocessing 


\subsubsection{The PUREX Process}

In addition to fission products, the spent fuel from a nuclear reactor contains a significant quantity of fissile isotopes (primarily U-235 and Pu-239), and a large quantity of fertile isotopes (primarily U-238). Some of these have chemical similarity, notably Uranium and Plutonium. PUREX was developed for the separation of Uranium from Plutonium. The principle of PUREX is illustrated in Figure 3-12, and the principal steps of the process are shown in Figure 3-13.

The PUREX process is used for the processing of irradiated uranium oxide fuels by solvent extraction. The solvent used in this process is a solution of tributyl Phosphate (TBP) in a high boiling point hydrocarbon, frequently n-dodecane or a mixture of similar hydrocarbons. TBP forms complexes with uranyl nitrate $\left[\mathrm{UO}_{2}\left(\mathrm{NO}_{3}\right)_{2}\right]$ and tetravalent plutonium nitride $\left[\mathrm{Pu}\left(\mathrm{NO}_{3}\right)_{4}\right]$. The concentration of these complexes in the hydrocarbon phase is higher than in an aqueous solution of nitric acid in equilibrium with the hydrocarbon phase. On the other hand, TBP complexes of most fission products, as well as trivalent plutonium nitrate have lower concentrations in the hydrocarbon phase than in the aqueous phase when in equilibrium. Next ferrous sulfamate is used to reduce plutonium to trivalent form (aqueous soluble), while the hexavalent uranium is unaffected (still soluble in the organic). At this point, the plutonium is separated from the uranium. A more detailed description of the PUREX process can be found in the supplementary references for this section $[55,56,57,58,59,60]$. 


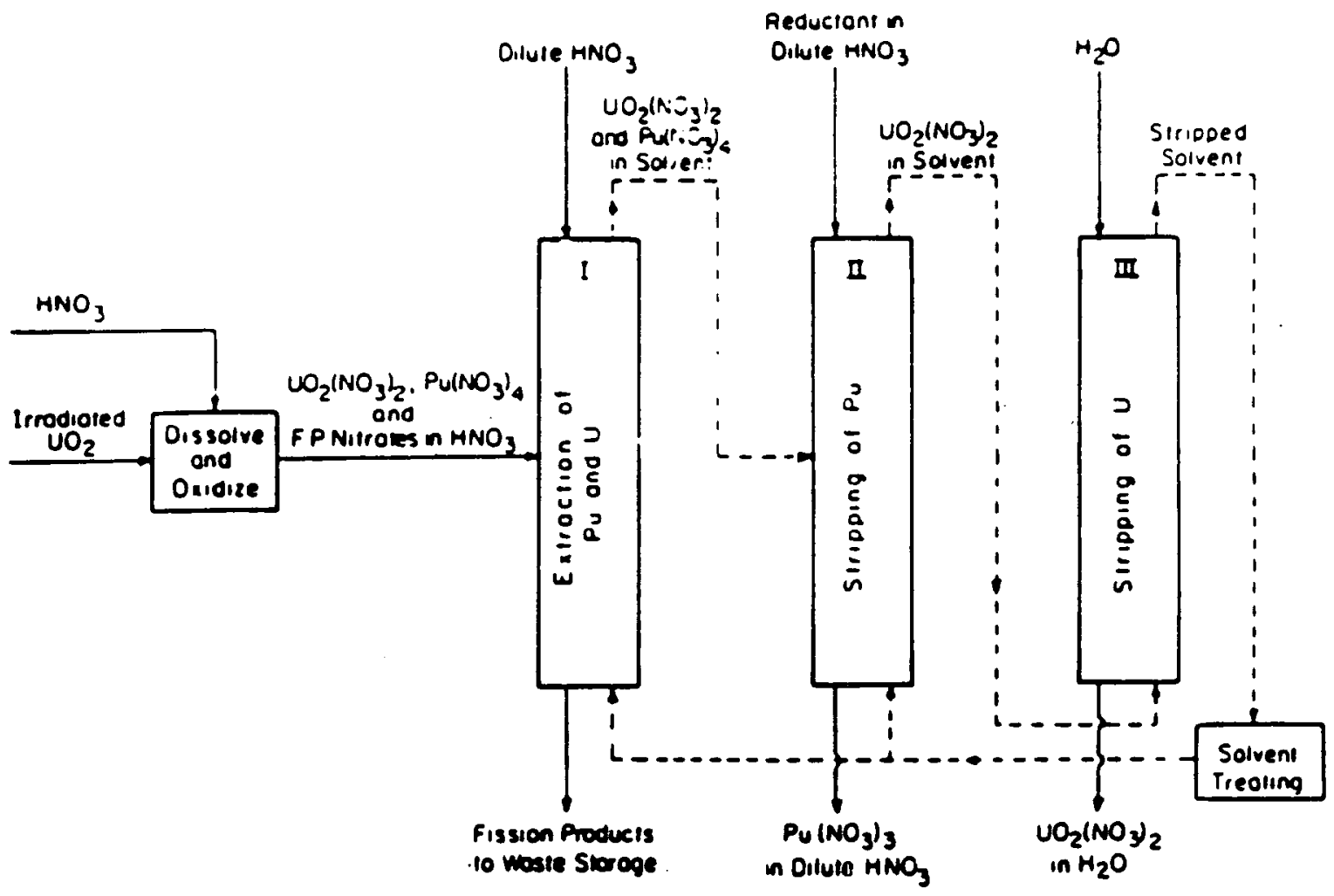

Figure 3-12: Principle of the PUREX Process 


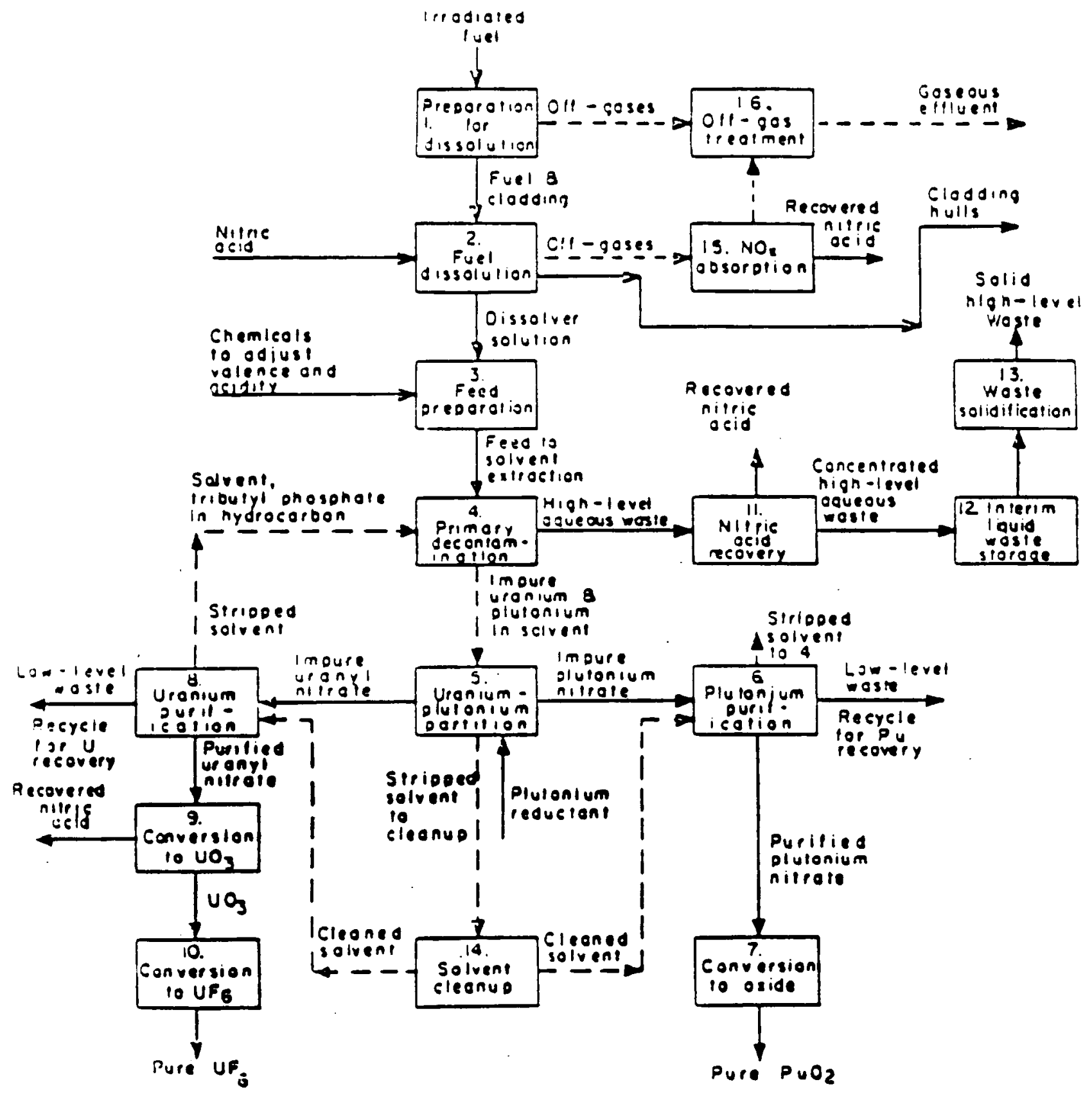

Figure 3-13: Principle Steps in the PUREX Process 
Compared to other liquid extraction processes, the PUREX process has the following advantages:

(1) PUREX produces a much lower volume of waste.

(2) TBP is a less volatile and less flammable solvent.

(3) TBP is very stable under the operating conditions, particularly the high radiation field.

(4) PUREX has a lower operating cost.

\subsubsection{The TRUEX Process}

The TRUEX (Transuranic Extraction) process is used to extract the actinide elements from the waste streams coming out of the PUREX process. A flowsheet for a generic TRUEX process is shown in Figure 3-14. A description of the major chemical operations in the TRUEX process is given below.

The TRUEX process is a new generic liquid-liquid actinide extraction/recovery process for the removal of actinide isotopes from the acidic nitrate or chloride waste stream solutions of the PUREX process. The generic TRUEX process includes the following steps $[61,62]:$
(A) Extraction/Scrub Step
(B) Strip Step 
(C) Solvent Wash Step

(D) Solvent Cleanup Step

The solvent, a new actinide-lanthanide selective solvent extractant, is octyl(phenyl)$\mathrm{N}, \mathrm{N}$-diisobutylcarbamoylmethyl-phosphine oxide. It is usually identified as $\mathrm{O} \varnothing \mathrm{D}(\mathrm{iB}) \mathrm{CMPO}$, or simply CMPO. CMPO has a combination of substituent groups which give it very favorable properties as an actinide extractant. Most important is its ability to extract trivalent actinides from low to high concentrations of $\mathrm{HCl}$.

Additional information on the TRUEX process can be found in the references cited in this report: $[63,64,65,66,67,68]$. 


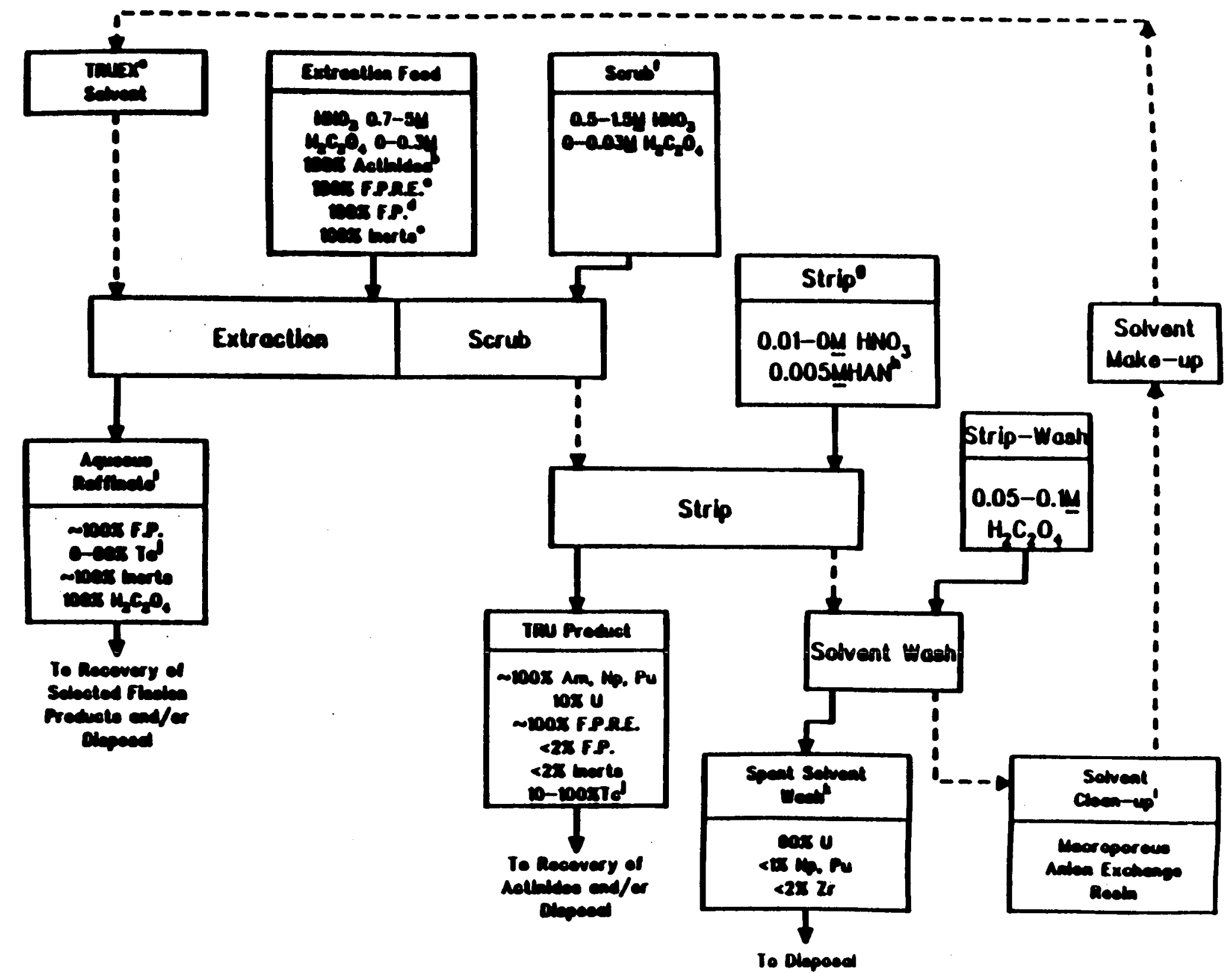

Figure 3-14: Generic TRUEX Process Flowsheet 


\subsubsection{Pyrometallurgical Reprocessing}

As an alternative route to the PUREX/TRUEX process for treating LWR spent fuel, a pyrochemical process can be used to reduce the spent oxide fuel and to separate out a rather impure TRU-rich metallic product. This product is then purified by the pyrometallurgical process developed for the metal alloy fuel of the Integral Fast Reactor (IFR). Due to the electrochemical similarity of the actinide elements the minor actinides $(\mathrm{Np}, \mathrm{Am}$, and $\mathrm{Cm})$ are returned to the reactor along with the plutonium and the remaining uranium in the product steam of the IFR pyroprocess. Because of this important feature, all of the actinides can be utilized in the IFR. The waste from the IFR pyroprocess is projected to have a low TRU content $(<150 \mathrm{nCi} / \mathrm{g})$, but the fuel produced will contain significant amount of fission products, primarily rare earths [69].

A simplified flowsheet of the salt transport process proposed for LWR spent fuel is shown in Figure 3-15. The feed to this process is assumed to be declad uranium oxide fuel. There are two product streams - a TRU-rich alloy and a uranium-rich metal alloy, and two major waste streams - salt from the reduction step and salt from salt transport. Both of these salt waste streams undergo further treatment with most of these salts being returned to the process and only a small fraction being packaged for disposal. The reduction salt is treated by electrolysis to convert the $\mathrm{CaO}$ byproduct back into the calcium metal reductant. Most of this salt is recycled, but a portion must be removed as waste to remove alkali metal and alkaline earth fission products from the process. The waste transport salt is contacted with a strongly reducing metal alloy, such as $\mathrm{Cu}-\mathrm{Mg}-\mathrm{Ca}$, to remove any rare earth fission 


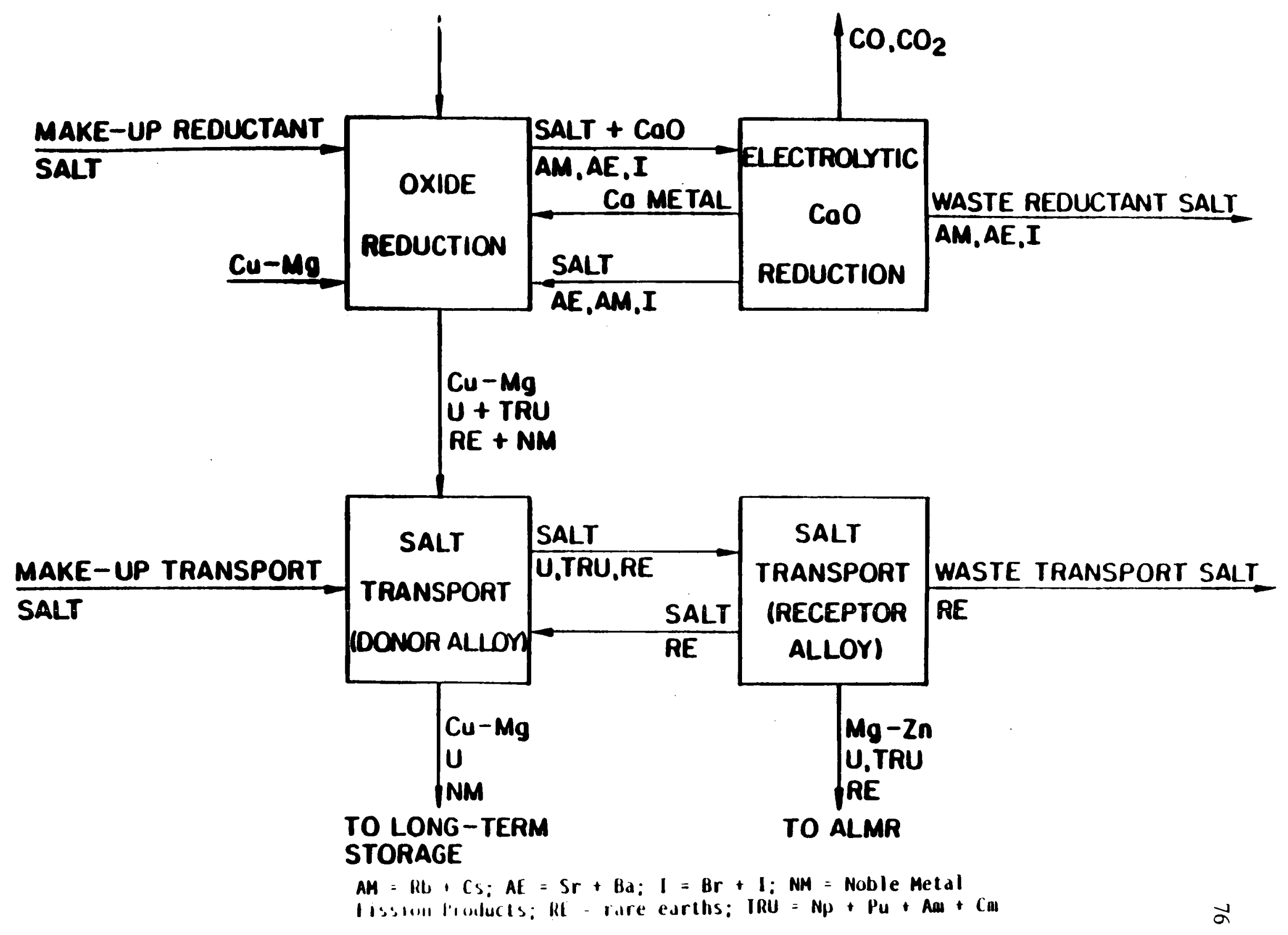

Figure 3-15: Simplified Flowsheet of Salt Transport Process for LWR Fuels 
products. Nearly all of this treated salt is returned to the salt transport process with only a small fraction (app. 5\%) being mixed with the discarded reduction salt and packaged for ultimate disposal. A flowsheet for the standard Integral Fast Reactor pyrometallurgical reprocessing operation is shown in Figure 3-16. The IFR fuel cycle process for metallic alloy fast reactor fuel is discussed in more detail in Section 3.2.3., and therefore will not be discussed in detail here. Additional information on both the IFR pyrometallurgical reprocessing operation and the pyrochemical reduction process proposed for the reduction of thermal reactor oxide fuel into metal can be found in the following references: $[70,71$, $72,73,74]$. 


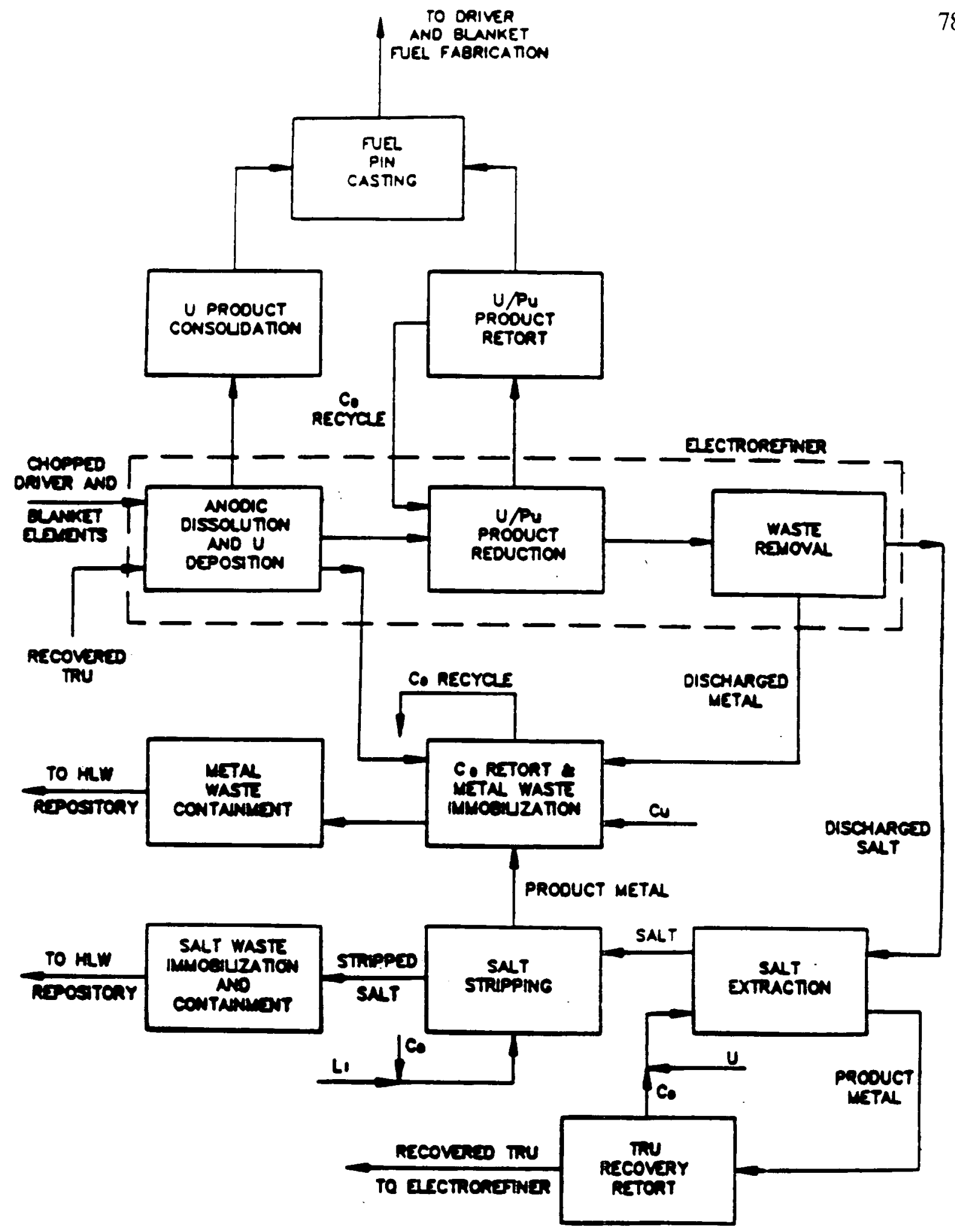

Figure 3-16: Pyrochemical Electrorefining Process and Waste Treatment for IFR Fuels 


\section{SECTION 4: THREE SCENARIOS FOR THE FUTURE}

\subsection{Overview}

Of the many possible combinations of the reactor types and processing operations described in the preceding chapter, three specific scenarios have been selected for analysis. The flowsheets for each of these scenarios, Scenarios 1, 2 and 3, are shown in Sections 4.2, 4.3, and 4.4, respectively. These three were chosen to represent the widest scope of likely nuclear power futures within a manageable number of scenarios.

The first scenario represents a steady-state future in which only Integral Fast Reactors (IFRs) are used for nuclear power generation. This presumes that by this time all current generation Light Water Reactors (LWRs) have reached the end of their operating lives and have not been replaced by similar LWRs. This "IFRs Only" scenario obviously represents one extreme future, but as such also represents an excellent bounding reference case for comparison. This scenario, Scenario 1, is presented in more detail in Section 4.2.

The second scenario represents a steady state future in which thermal reactors, either current or advanced Light Water Reactors (LWRs) or advanced Modular Gas-Cooled Reactors (MGRs), exist in a symbiotic overall nuclear power system along with Integral Fast Reactors (IFRs). In this scenario the thermal reactors serve as the primary producers of nuclear powered electricity generation, while the IFRs serve primarily as dedicated burners for the transuranic (TRU) wastes from the thermal reactors. The IFRs also produce electricity to add to the overall power generation, but their primary purpose is to perform 
as actinide burners for the high-level radioactive wastes produced by all of the reactors in the system. In this way, essentially all of the actinides (both uranium and the transuranics) are extracted from the high-level wastes before they are shipped to a geologic repository for ultimate disposal. This scenario is intended to show the limits at which the IFR can be operated as a dedicated actinide burner. The result will be a determination of the maximum achievable ratio of (MWe from thermal reactors)/(MWe from IFRs) that can be obtained in this symbiotic system while still producing only a high-level waste form which is essentially free from the long-lived hazards posed by the actinide isotopes. It should be noted that in this scenario the bulk of the uranium contained in the spent fuel from the thermal reactors (which comprises a vast majority of the mass of that fuel) is stored for future use, and is not burned up in the IFRs. This scenario, Scenario 2, is presented in more detail in Section 4.3.

The third scenario represents a system which could be put in place now using developed, proven technology. This scenario involves only oxide fueled thermal reactors, either Light Water Reactors (LWRs) or Modular Gas-Cooled Reactors (MGRs), with no Integral Fast Reactors (IFRs). The removal of essentially all of the actinide elements from the ultimate high-level waste form in this scenario is achieved by aqueous reprocessing. The reprocessing scheme consists of the conventional PUREX reprocessing system followed by the TRUEX reprocessing system used to recover essentially all of the remaining actinides from the PUREX waste stream. It is important to note that the portion of this scenario located above the dashed line in the Scenario 3 flowsheet illustrates the steps which are currently being followed by all domestic commercial nuclear power plants. Note also, that even though this scenario involves spent fuel reprocessing, it is still only a once-through fuel 
cycle. This is not an "actinide-burning" scenario, but is instead an "actinide-storing" scenario in which the actinide isotopes, the uranium and the transuranics (TRUs), are separated out and stored for future use. This scenario, Scenario 3, is juxtaposed against Scenario 1 in that it represents the extreme of what could be done to produce only essentially actinide free high-level radioactive wastes using only thermal reactors, without the use of the IFR or its pyrochemical separation processes. This scenario, Scenario 3, is presented in more detail in Section 4.4.

Obviously some intermediate scenarios, particularly somewhere between Scenarios 1 and 3, can be imagined, but the scenarios selected here have been chosen specifically to illustrate the limiting cases. Further combinations and refinements can be made later as an extension of this work.

The material flows and support ratios in these scenarios are quantified in Section 4.5. Section 4.5 quantifies the inputs and outputs for each of the three scenarios in terms of mass flows per unit of electricity generated. The material flows and the resulting end-point waste streams for Scenarios 1, 2 and 3 are calculated and a reactor power support ratio is determined for the combined thermal reactor/IFR actinide burner system of Scenario 2.

\subsection{Scenario 1: IFRs Only}

This scenario represents a steady-state future in which only Integral Fast Reactors (IFRs) are used to generate electricity with nuclear power. By the time that this scenario 
is operational it is assumed that all Light Water Reactors (LWRs) will have been permanently shut down. In this scenario, the IFR acts as its own actinide burner by means of its integral fuel reprocessing cycle. At steady-state, the only fuel input is makeup uranium, either natural uranium or depleted uranium stockpiled as a byproduct of LWR fuel enrichment. The flowsheet for Scenario 1 is illustrated in Figure 4-1. A detailed description of the operation entailed in this scenario is given below.

The inputs to this. "IFRs Only" scenario are illustrated by the rounded rectangles at the top of Figure 4-1. The only input is uranium, either natural uranium with an enrichment of $0.711 w t \%$ U-235, or depleted uranium with a typical enrichment of $0.2 \mathrm{wt} \%$ U-235. The uranium input is used as makeup for the IFR blanket assemblies, and hence requires only U-238. The low U-235 enrichment of the feed material is therefore not a problem. Scenario 1 presents an excellent opportunity to consume the large quantity of depleted uranium stockpiled in the United States which is not useful for thermal reactors (which require a significant enrichment in U-235) and which may also pose a significant health risk. This is one of the primary advantages of this scenario.

The low enrichment uranium is fed to the IFR fuel fabrication process where it is mixed with the combination of uranium, transuranics (especially plutonium which acts as the primary fissile fuel isotope), a fraction of the rare earth fission products and alloy zirconium. These metals are combined in ratios appropriate to yield a U-TRU-Zr metal alloy fuel which meets the fissile fuel requirements of the specific application, be it driver fuel or blanket fuel. The fuel is injection cast into pin shapes by pressure ramming the molten alloy into zirconium molds. The fuel pins are then encapsulated in stainless steel cladding along with 


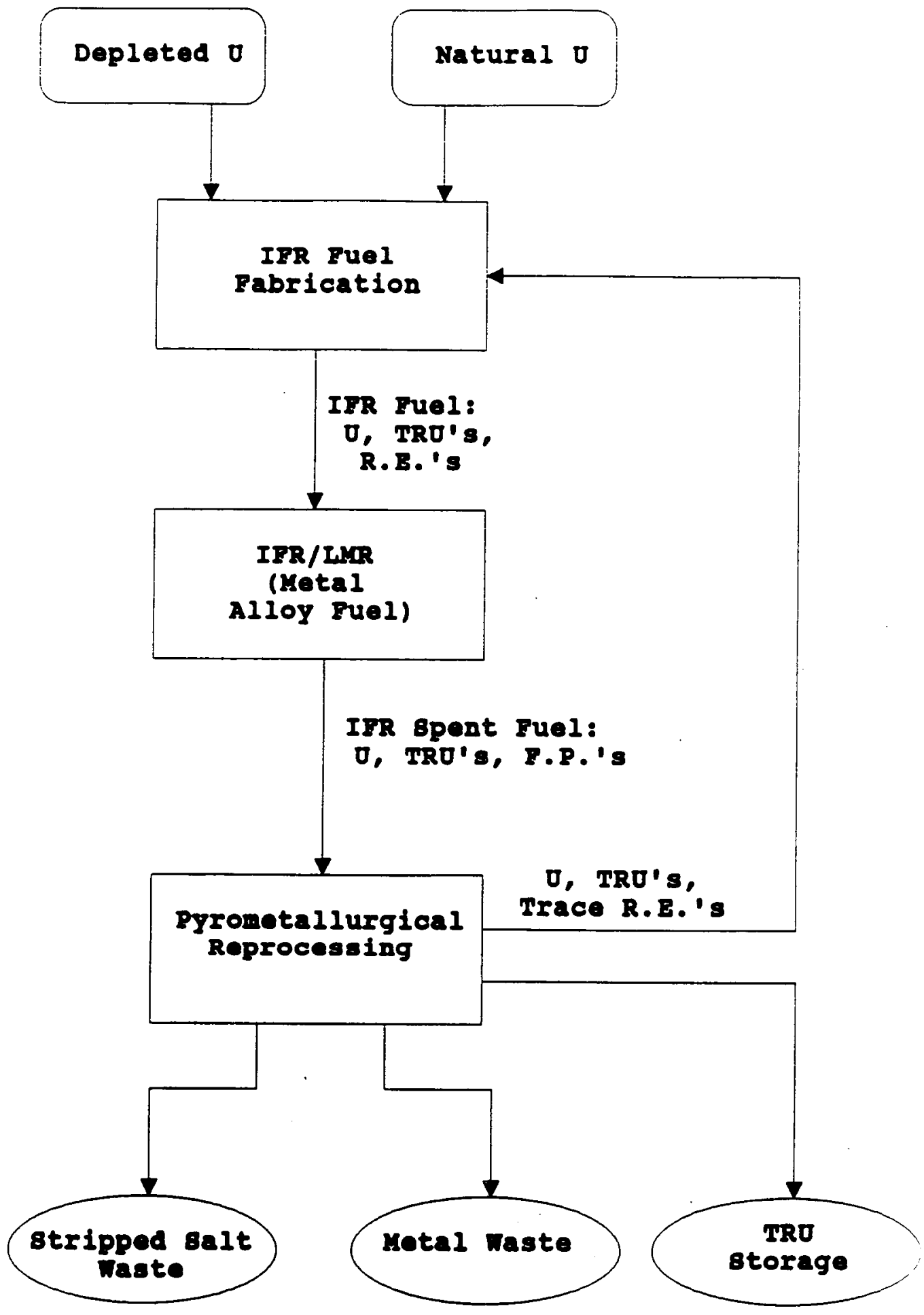

Figure 4-1: Scenario 1 Flowsheet (IFRs Only) 
a quantity of sodium which is used to thermally bond the metal alloy fuel pins to the stainless steel cladding.

The completed IFR fuel is then charged to the IFR core. The fuel is burned in the reactor for four cycles and is discharged with an average burnup of $92,000 \mathrm{MWD} / \mathrm{MTHM}$ [37]. The spent IFR fuel is cooled on-site for a period of one year before undergoing reprocessing.

After the one year cooling period, the spent fuel is routed to the on-site fuel reprocessing facility. In this facility the spent fuel is put through the pyrometallurgical reprocessing operation described in Section 3.3.4. There are three major output streams from this operation.

The first product stream contains essentially all of the uranium and transuranics contained in the spent IFR fuel, in addition to a fraction (typically $1 / 8$ to $1 / 10$ ) of the rare earth fission products. The rare earth fission products follow the actinides through the separation processes. The rare earth decontamination factor of the actinide product stream decreases (i.e. more rare earths follow the product stream) as the transuranic (TRU) separation factor increases. These rare earths, however, do not cause a problem for the IFR because their absorption cross sections, which are very high in the thermal spectrum of an LWR, are negligible in the fast neutron spectrum of the IFR. The resulting product stream is sent to the IFR fuel fabrication operation where it is mixed with the new makeup uranium and is formed into new IFR metal alloy fuel assemblies for charging back to the IFR core. A second product stream contains a small quantity of TRU elements which exceed the needs of the IFR fuel fabrication process. This is because the self sufficient IFR analyzed in 
Scenario 1 has a breeding ratio slightly larger than unity. This stream of TRU elements will be put into storage for eventual used in the initial startup cores of other IFR power plants.

The two other primary product streams from the pyrometallurgical reprocessing operation are waste streams. The first of these is the stripped salt waste stream. This waste stream contains alkali metal, alkaline earth, and halide fission products including both strontium and cesium in addition to large quantities of process and bond salts. The bond salt is $\mathrm{NaCl}$ made up of sodium ( $\mathrm{Na}$ ) put into the IFR fuel rods to thermally bond the metallic alloy fuel pin to the stainless steel fuel cladding, which combines with chlorine $(\mathrm{Cl})$ in the electrolyte during the IFR electrorefining process. This waste stream can be considered essentially actinide free as it is projected to contain less than $150 \mathrm{nCi} / \mathrm{g}$ of alpha emitting isotopes [42]. From a TRU standpoint, and after 300 years when the fission products have essentially decayed away, this waste stream qualifies as a low level waste form, but in the near term, the high radioactivity and high heat content of this stream clearly make it a high-level waste form, thus requiring isolation from the biosphere. Current plans call for this waste stream to be dispersed into a ceramic matrix, and for the resulting waste form to be encapsulated in a sealed metal canister [42].

The second waste steam from the pyrometallurgical reprocessing operation is the metal waste stream. This waste stream contains the noble metal and rare earth fission products, a small quantity of uranium, plus the chopped fuel cladding segments, the alloy zirconium from the fuel, and residual cadmium from the electrorefining process. The metal waste stream also contains the used or damaged process wastes such as fuel pin molds and electrorefiner parts which have been reduced into pieces roughly the size of the fuel cladding 
segments, about one-half of an inch in length [42]. This steam is projected to contain only $0.1 \%$ or less of the transuranics contained in the spent fuel, meaning that $>99.9 \%$ of the TRUs are recovered in the process and fed back to the IFR core [42]. The metal waste stream is to be dispersed into a copper matrix, with the resulting copper/waste ingot being encapsulated in a sealed metal canister.

Both of the waste streams, the stripped salt waste and the metal waste, are hazardous enough in the near term that they require emplacement in some type of disposal facility, such as an underground geologic repository, for a substantial period of time. The stripped salt waste is essentially free of actinides ( $>150 \mathrm{nCi} / \mathrm{g}$ alpha emitters) and therefore only need to be isolated for about 300 years, until such time as the bulk of the fission products have decayed away. The metal waste, on the other hand, contains a reduced, but still important quantity of actinide elements and must be isolated permanently.

\subsection{Scenario 2: Thermal Reactors with IFRs as Actinide Burners}

Scenario 2 represents a steady-state symbiosis between thermal reactors, either current or advanced Light Water Reactors (LWRs) or Modular Gas-Cooled Reactors, and Integral Fast Reactors (IFRs) which serve primarily as actinide burners. This scenario is illustrated by the flowsheet of Figure 4-2. A detailed description of the operations entailed in this scenario is given below.

The only nuclear material input to this symbiotic scenario is the natural uranium input 
BCENARIO 2 - Thermal Reactor with

IFR Actinide Burner

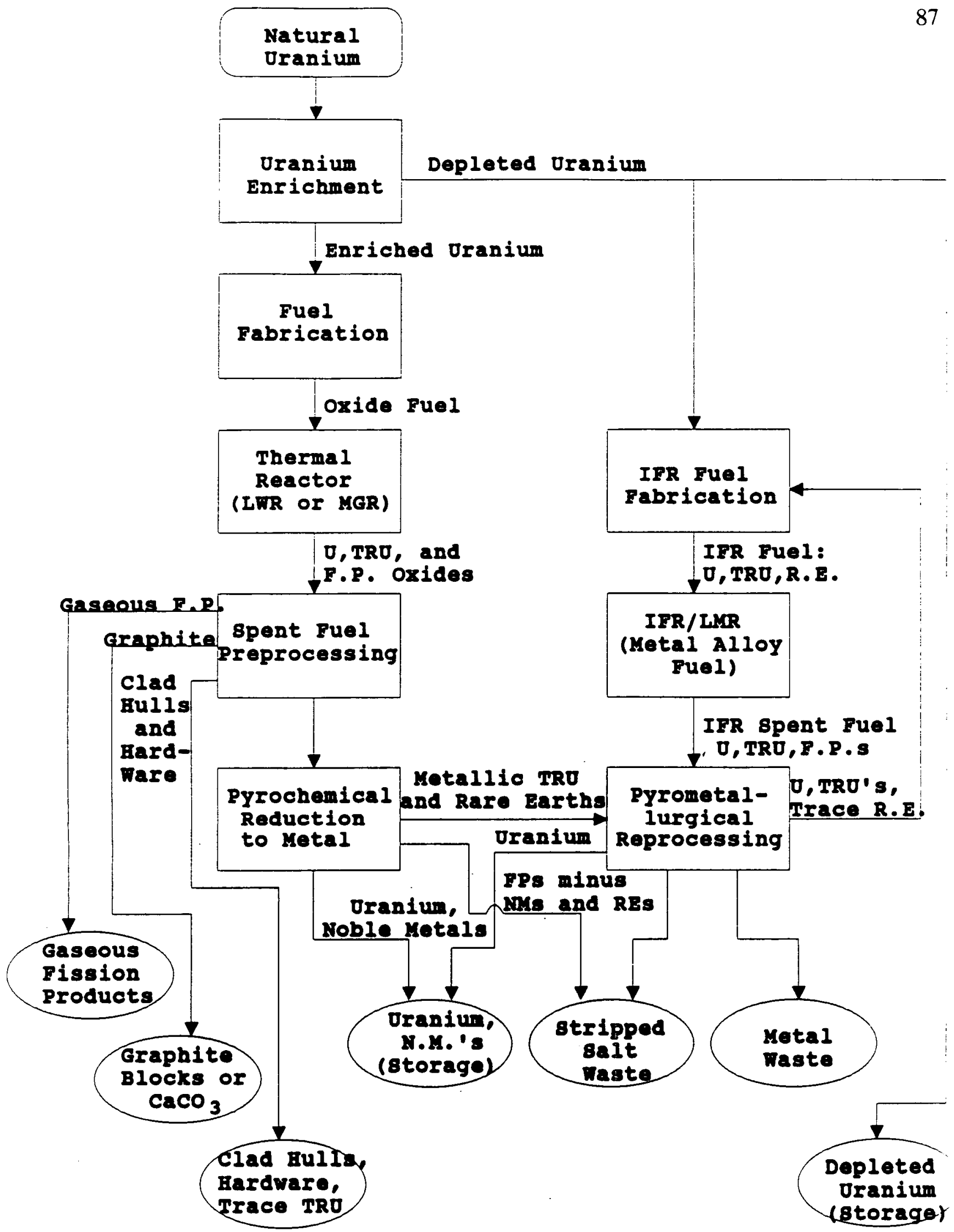

Figure 4-2: Scenario 2 Flowsheet (Thermal Reactors with IFRs as Actinide Burners) 
at the top of the flowsheet. The natural uranium input is sent to a uranium enrichment facility where its original U-235 content of $0.711 \mathrm{wt} \%$ is increased either via gaseous diffusion or gas centrifuge to the higher enrichments used in a thermal reactor (from $3.5 \%$ for LWRs up to $19.8 \%$ for MGRs). The "waste" stream from this process is a large flow of depleted uranium which has a reduced $(0.2 \mathrm{wt} \%)$ U-235 content. In this scenario, the depleted uranium is sent to the IFR fuel fabrication process for use as makeup uranium. The enriched uranium stream is sent to a fuel fabrication facility where it is converted into uranium dioxide $\left(\mathrm{UO}_{2}\right)$ and is formed into either ceramic fuel pellets for the $\mathrm{LWR}$, or into TRISO fuel particles for the MGR. The LWR and MGR fuel assemblies are completed as discussed in Chapter 4 and are routed to their respective reactors. In the reactors, the LWR fuel is burned for either 3 or 4 cycles to an average discharge burnup of 33,000 MWD/MTHM [42], and the MGR fuel is burned either in prismatic form for 4 cycles to an average burnup of $82,460 \mathrm{MWD} / \mathrm{MTHM}$ [37], or in pebble form to an average discharge burnup of 80,544 MWD/MTHM [38]. After discharge from the reactor, the thermal reactor spent fuel is cooled in an on-site storage facility (water filled pool for LWR fuel and aircooled vault for MGR fuel) for a period of two years.

Following the two-year cooling period, the thermal reactor fuel is sent for spent fuel preprocessing, described in more detail in Section 3.3.1. For MGR spent fuel, the primary waste streams from the preprocessing operation are: gaseous fission products liberated during the crushing of the TRISO silicon carbide layer, combusted graphite (carbon) immobilized in calcium carbonate $\left(\mathrm{CaCO}_{3}\right)$, and potentially the large prismatic blocks if the fuel "sticks" are pushed out prior to reprocessing. All of these wastes are projected to fall 
below Low Level Waste Class C limits. For LWR spent fuel, the primary waste streams from the preprocessing operation are: gaseous fission products liberated when the fuel pellets are crushed and the cladding is cut open, and the hardware from the LWR fuel assemblies including the ends of the assembly and the Zircaloy cladding hulls. The LWR hardware wastes are assumed to be contaminated with trace amounts of fission products and actinides and therefore classified as high-level waste.

The product stream from the thermal reactor spent fuel preprocessing is the point where the two streams, the one from the LWR and the one from the MGR, converge. The product stream from the preprocessing operation is the spent fuel oxide. This consists of a combination of uranium dioxide, transuranic (TRU) and fission product oxides. This oxide mixture is sent to the pyrochemical reduction-to-metal step discussed earlier in Section 3.3.1. In this step the combination of oxides in the spent fuel is reduced to a metallic product stream to be input to the standard IFR pyrometallurgical reprocessing operation. The principal byproduct of this step is a stream containing all of the uranium as well as the noble metal fission products which were contained in the spent fuel oxide input. This uranium rich metallic byproduct stream is separated from the remainder of the actinides because the IFR actinide burner system cannot handle the addition of this large mass flow of additional uranium as feed to either the pyrometallurgical reprocessing step or to the fuel fabrication step. The IFR simply cannot "swallow" this quantity of uranium. Current plans call for storing this excess metallic uranium stream for undefined future uses, possibly as feedstock for starting up additional IFRs in the future or as feed to standard thermal reactor fuel enrichment. The noble metal fission products follow the uranium through the reduction-to- 
metal process and end up in metallic form alloyed with the uranium. If necessary, these noble metal fission products can be removed from the uranium by using an. additional pyrochemical process, although this is not included in current plans. Another stream from the pyrochemical reduction-to-metal process is a stripped salt waste stream containing the alkali metal, alkaline earth, and halide fission products from the thermal reactor fuel. This stripped salt waste stream is combined with the stripped salt waste stream from the IFR pyrometallurgical reprocessing operation and is absorbed into a ceramic matrix and then encapsulated in a sealed metal canister.

The primary product stream from the reduction to metal process is a metallic stream containing "essentially all" (the separation has not yet been firmly quantified) of the transuranic (TRU) isotopes in the spent fuel plus the rare earth fission products. This metallic stream is fed directly into the IFR pyrometallurgical reprocessing operation along with spent fuel from the IFR. In this operation the actinides and about $1 / 8$ of the rare earth fission products contained in the spent fuel feed are separated out and routed back to the IFR fuel fabrication operation where they are formed into fresh fuel assemblies for charging to the IFR in order to generate electricity.

The IFR Actinide Burner analyzer in this Scenario requires no make-up flow of uranium. The uranium and TRU flow from the IFR along with the TRU flow from the Thermal Reactors combine to provide the necessary heavy metal fuel make-up. Unlike the standard IFR of Scenario 1 which utilizes blanket assemblies to achieve an overall breeding ratio of 1.171 [42], the Actinide Burner IFR has stainless steel reflector assemblies instead of fertile blanket assemblies and as a result operates as a burner reactor with a breeding 
ratio of 0.218 [42]. After the fuel is burned in the actinide burner IFR, it is discharged to a cooling pond and cooled for a period of one year before undergoing reprocessing.

After this cooling period, the spent fuel is routed to the on-site fuel reprocessing facility. Here it is mixed with the metallic TRU/fission product stream from the thermal reactor pyrochemical reduction to metal process discussed earlier. The combined streams are run through the pyrometallurgical reprocessing operation described on Section 3.3.4. There are four major output streams from this operation. These streams are similar to the product and waste streams described in Scenario 1 for the pyrometallurgical reprocessing operation. The stripped salt waste and metal waste are qualitatively identical to the waste streams of Scenario 1. Similarly, the product steam which returns to the IFR Fuel Fabrication Process is qualitatively identical to its counterpart in Scenario 1. However, the minor product steam in Scenario 2 is a small mass flow of excess uranium to storage with no TRU, whereas in Scenario 1 the minor product stream is a small mass flow of TRU to storage with no uranium. A more detailed description of these streams can be found in Section 4.2, under Scenario 1.

\subsection{Scenario 3: Thermal Reactor with PUREX/TRUEX Reprocessing}

Scenario 3 represents a scenario which could be put in place today using proven current technologies. Basically, this scenario represents what could be done to reduce the long-lived actinide component of high-level radioactive waste from current generation 
commercial reactors without use of the Integral Fast Reactor (IFR) or its attendant pyrometallurgical fuel reprocessing scheme. Scenario 3 is illustrated by the flowsheet in Figure 4-3. Scenario 3 involves only thermal reactors, and hence could be based solely on today's generation of Light Water Reactors (LWRs). In fact, everything which is above the dotted line in the Figure 4-3, the Scenario 3 flowsheet, defines the scenario we currently have in operation in the United States. Advanced LWRs and Modular Gas-Cooled Reactors (MGRs) could also be used in this scenario. This scenario is not truly an "actinide burning" scenario, as are Scenarios 1 and 2, but can instead be thought of as an "actinide partitioning and storage" strategy. This scenario makes use of proven aqueous reprocessing operations to remove the actinide content of the thermal reactor high-level wastes. The aqueous reprocessing scheme is a combination of the standard PUREX process augmented by the newer TRUEX process, used to extract the remaining transuranics (TRUs) from the waste stream coming out of the PUREX process. A detailed description of the operations entailed in Scenario 3 is given below.

The only nuclear material input to this is the natural uranium input at the top of the flowsheet shown in Figure 4-3. The natural uranium input is sent to a uranium enrichment facility where its original U-235 content of 0.711 wt\% is increased either via gaseous diffusion or gas centrifuge to the higher enrichment (3.5\% to $19.8 \%$ ) needed to operate a thermal reactor (LWR and MGR, respectively). The waste stream from this process is a large flow of depleted uranium which has a reduced ( $0.2 \mathrm{wt} \%)$ U-235 content compared to the natural uranium feed. The depleted uranium is put into indefinite storage either for future use or eventually to be disposed of as waste. It must be kept in mind that as uranium 
SCENARIO 3 - Thermal Reactor with

PUREX/TRUEX Reprocessing

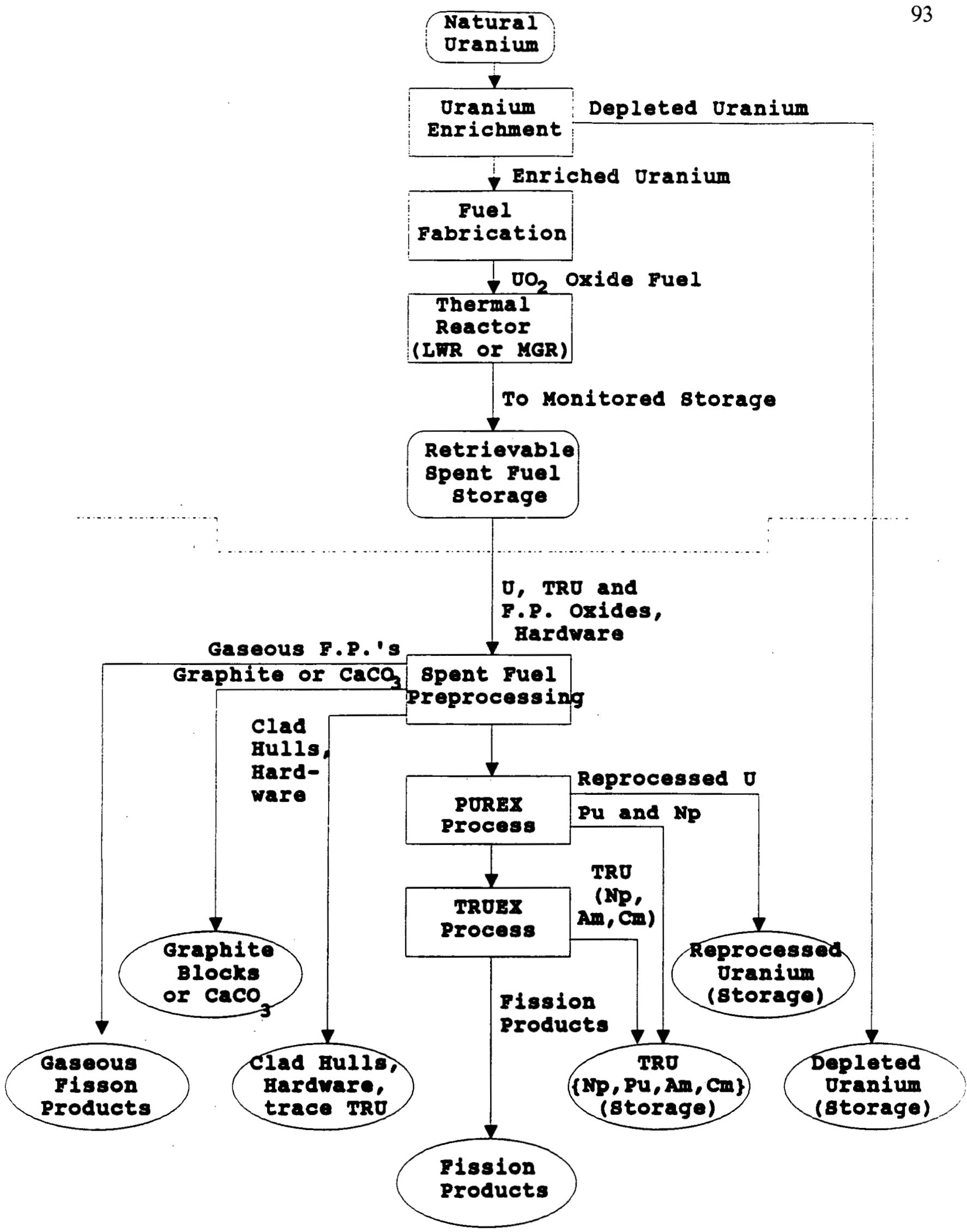

Figure 4-3: Scenario 3 Flowsheet (Thermal Reactors with

PUREX/TRUEX Reprocessing) 
this represents an actinide waste/storage stream. The enriched uranium stream is sent to a fuel fabrication facility where it is converted into uranium dioxide $\left(\mathrm{UO}_{2}\right)$ and formed into either ceramic fuel pallets for the LWR, or into TRISO fuel particles for the MGR. The LWR and MGR fuel assemblies are completed as discussed in Chapter 4 and are routed to their respective reactors. In the reactors, the LWR fuel is burned to an average discharge burnup of 33,000 MWD/MTHM [42], and the MGR fuel is burned either in prismatic form to an average burnup of $82,460 \mathrm{MWD} / \mathrm{MTHM}$ [37], or in pebble form to an average discharge burnup of 80,544 MWD/MTHM [38]. After discharge from the reactor, the thermal reactor spent fuel is sent to a monitored storage facility. This storage facility could either be on-site, as is currently the case for domestic LWRs, or off-site at a centrally located monitored retrievable storage facility of the type proposed by the Department of Energy. The spent fuel storage for LWR fuel can be either a water-filled storage pool, as is used at every commercial nuclear power plant in the United States for on-site storage, or on-site concrete or metal dry storage casks, as is being implemented at a significant and increasing number of commercial nuclear power plants throughout the United States. The spent fuel storage for MGR fuel could be either air-cooled vault storage, such as that used at the Fort St. Vrain nuclear power plant [75], or in concrete or metal dry storage casks.

This is the current endpoint for the scenario being played out in the United States today. Currently, spent fuel is being stored indefinitely at on-site storage facilities awaiting the time when the federal government is supposed to take permanent possession of the fuel. According to the original "Nuclear Waste Policy Act of 1982" [31], the Department of Energy (DOE) is legally obligated to begin taking the spent fuel from domestic nuclear 
reactors. The law does not, however, say anything about how much or at what rate the DOE is to take the fuel. It may be many decades before all of the fuel is shipped off-site by the DOE. There is also much debate concerning whether the DOE will actually meet the 1998 deadline; many feel that the DOE will miss this target by at least a decade. Current DOE plans call for disposing of the spent fuel as canistered intact fuel assemblies in an underground geologic repository. This scenario, Scenario 3, differs from the DOE plans in that it postulates reprocessing the spent fuel in order to remove all of the actinide elements from the high-level waste stream before it is disposed of in a geologic repository.

The first step in this actinide separation and storage process is preprocessing of the spent fuel. The purpose of this step is to reduce the thermal reactor fuel from intact LWR or MGR spent fuel assemblies to spent fuel oxide, stripped of any hardware, binders or cladding, for feed to PUREX aqueous reprocessing. After the spent fuel is cooled/stored for an indefinite period of time, assumed to be two years in this study for consistency with the other scenarios, the thermal reactor fuel is sent for spent fuel preprocessing (described in more detail in Section 3.3.1). For MGR spent fuel, the primary waste streams from the preprocessing operation are: gaseous fission products liberated during the crushing of the TRISO silicon carbide layer, combusted graphite (carbon) immobilized in calcium carbonate $\left(\mathrm{CaCO}_{3}\right)$, and potentially the large prismatic blocks if the fuel "sticks" are pushed out prior to reprocessing. All of these wastes are projected to fall below Low Level Waste Class C limits. For LWR spent fuel, the primary waste streams from the preprocessing operation are: gaseous fission products liberated when the fuel pellets are crushed and the cladding is cut open, and the hardware from the LWR fuel assemblies including the ends of the 
assembly and the Zircaloy cladding hulls. The LWR hardware wastes are assumed to be contaminated with trace amounts of fission products and actinides and therefore will be considered to be high-level waste.

The two streams, the one from the LWR and the one from the MGR, converge at this point. The product stream from the preprocessing operation is the spent fuel oxide from the thermal reactors. This consists of a combination of uranium dioxide, transuranic (TRU) and fission product oxides.

This oxide spent fuel stream is fed into the PUREX process described in Section 3.3.2 of this report. The primary product streams from the PUREX process are a stream containing essentially all of the uranium contained in the spent fuel and a stream containing about $99 \%$ of the plutonium and about $50 \%$ of the neptunium in the spent fuel. The separated uranium stream will be shipped to a storage facility and stored in the same manner as the depleted uranium stream from the uranium enrichment process described earlier. This uranium could be used as feed to the thermal reactor fuel enrichment operation, or for some other, as yet undetermined, purpose. The second product stream, which contains a mixture of the transuranic (TRU) elements plutonium and neptunium, would be shipped to a specially designed shielded storage facility where it would be stored for undetermined future uses. Such a facility to house concentrated TRU isotopes has not yet been dèsigned.

The waste stream from the PUREX process contains all of the fission products in the spent fuel and fractions of all of the TRU isotopes in the spent fuel. This waste stream is routed to the TRUEX process described in Section 3.3.3 of this report. The TRUEX 
process was developed specifically to strip the remaining TRU isotopes from the aqueous waste stream coming out of the PUREX process, in order to produce an actinide free waste for ultimate disposal. The product steam from the TRUEX process is essentially all of the remaining TRU isotopes in the spent fuel, the remaining $1 \%$ of the plutonium, $50 \%$ of the neptunium, and all of the americium, curium and any trace concentrations of higher actinide elements. The TRUEX designers claim to be able to achieve any level of actinide separation desired simply by increasing the number of separation stages in the reprocessing cascade. They claim that a separation of $99.99 \%$ can be achieved with a "reasonable" number of stages. This study will assume that $99.99 \%$ separation is what will be achieved. Further information on the TRUEX process can be found in the references cited in Section 3.3.3: references $[61,62,63,64,65,66,67,68]$. This mixture of TRU isotopes will be shipped to the same shielded storage facility as the TRU isotopes separated out by the PUREX process. The waste stream from the TRUEX process is an aqueous stream containing all of the fission products originally present in the spent fuel. This aqueous fission product waste stream would be solidified in some manner, most likely glassification as is done for defense high-level waste, and encapsulated in a metal canister and permanently disposed of in a facility such as a geologic repository. 


\subsection{Input, Output, and Mass Flows}

This section compiles the input stream data for each scenario, and using the flowsheet logic of that scenario, determines the internal mass flows within the scenario and the final output steams. The output stream mass flows all go either into storage or to waste disposal. All mass flow calculations are in units of mass per unit of electricity generation, $\mathrm{kg} / \mathrm{GW}-\mathrm{hr}_{\boldsymbol{e}}$. This common denominator is used so that all mass flows for any scenario can be compared on an equal footing. These units allow mass flows from different scenarios to be compared directly without having to consider such things as unit output, thermal efficiency, capacity factor, and burnup because these variable are included explicitly in the calculations used to arrive at mass per unit of electricity generated. These units are also significant because the ultimate product and purpose of these scenarios using nuclear power is the production of electrical power. These units of $\mathrm{kg} / \mathrm{GW}-\mathrm{hr}_{\boldsymbol{e}}$ thus serve as an excellent baseline for nuclear power studies.

All calculations referred to in this section were performed by hand. A computer code is being developed to model these and other nuclear power scenarios. The computer code will greatly facilitate the speed of calculations and the ease with which parameters can be changed in the future as new and additional data and information input is received. It is noted, however, that this initial hand calculation serves the useful and necessary steps of creating a baseline to which the computer model can be compared for code validation.

The complete calculations and the calculating methodologies and basis for each scenario are not included in this section, but are instead included in the Appendices. 
Summaries of the input and output mass flow steams are presented below.

The calculations in this report rely heavily on the data contained in the Argonne National Laboratory Report ANL-IFR-127, "Use of Transuranic Elements from LWR Fuel in Integral Fast Reactors" [42]. It should be noted that the ANL document is published under the federal government's Applied Technology policy. Appropriate care should be given to distribution of this document.

The summarized mass flows, in $\mathrm{kg} / \mathrm{GW}$-hr $\boldsymbol{e}_{\boldsymbol{e}}$, are given both in tabulated form and in graphical flowsheet form. Salient issues are discussed in the context of the individual scenarios.

Scenario 1

Scenario 1 involves IFR only in a steady-state future where all thermal reactors have been phased out and replaced by Integral Fast Reactors. The input and output mass flows for Scenario 1 are tabulated in Table 4-1. The mass flows are also presented graphically on the Scenario 1 flowsheet in Figure 4-4.

The IFR analyzed in Scenario 1, as labeled a "Self Sufficient IFR" by Argonne National Laboratory, actually functions as a breeder reactor having a Breeding Ratio of 1.171 [42]. This reactor is a "TRU Generator;" it breeds a small amount of TRU isotopes $(\mathrm{Np}, \mathrm{Pu}, \mathrm{Am}, \mathrm{Cm})$ which must be stored either in the process or in a storage facility. It is presumed that these excess TRU isotopes would eventually be used to manufacture the startup core for another IFR at some time in the future. It is also noted that this IFR is 
Table 4-1: Scenario 1 Input and Output Mass Flows (IFRs Only)

Basis: $\quad$ Actinides

IFR Self Sufficient Reactor

Rating $=450 \mathrm{MW}_{e}\left(1157 \mathrm{MW}_{t h}\right)$

Breeding Ratio $=1.171$

Efficiency $=0.389$

Capacity Factor $=0.89$

Fission Products

IFR Self Sufficient Reactor

Rating $=389 \mathrm{MW}_{e}\left(1000 \mathrm{MW}_{t h}\right)$

Breeding Ratio $=1.0$

Efficiency $=0.389$

Capacity Factor $=0.89$

All flows calculated on a per $\mathrm{GW}-\mathrm{hr}_{e}$ generated.

Flows:

A) Input:

1) Natural Uranium

$0.133 \mathrm{~kg} / \mathrm{GW}-\mathrm{hr}_{e}$

2) Depleted Uranium

$0.0 \mathrm{~kg} / \mathrm{GW}-\mathrm{hr}_{e}$

B) Output:

1) TRU - Storage

$0.0227 \mathrm{~kg} / \mathrm{GW}-\mathrm{hr}_{\boldsymbol{e}}$ made up of:
i) $\quad \mathrm{Np}$
$1.40 \times 10^{-4} \mathrm{~kg} / \mathrm{GW}-\mathrm{hr}_{e}$
ii). $\mathrm{Pu}$
$2.25 \times 10^{-2} \mathrm{~kg} / \mathrm{GW}-\mathrm{hr}_{e}$
iii) $\mathrm{Am}$
$-0$
iv) $\mathrm{Cm}$
$9.63 \times 10^{-5} \mathrm{~kg} / \mathrm{GW}-\mathrm{hr}_{e}$ 
Table 4-1 (continued): Scenario 1 Input and Output Mass Flows (IFRs Only)

B) Output (continued)

2) Stripped Salt Waste

(Fission Products)

$$
0.0206 \mathrm{~kg} / \mathrm{GW}-\mathrm{hr}_{e}
$$

made up of:

i) Uranium $\sim 0$

ii) Alkali Metals $\quad 0.013 \mathrm{~kg} / \mathrm{GW}-\mathrm{hr}_{e}$

iii) Alkaline Earths $\quad 6.26 \times 10^{-3} \mathrm{~kg} / \mathrm{GW}-\mathrm{hr}_{e}$

iv) Rare Earths $\quad \sim 0$

v) Halides $1.32 \times 10^{-3} \mathrm{~kg} / \mathrm{GW}-\mathrm{hr}_{e}$

Plus: $\quad$ Salts $0.291 \mathrm{~kg} / \mathrm{GW}-\mathrm{hr}_{\boldsymbol{e}}$

(LiCl Process Salt plus $\mathrm{NaCl}$ Bond Salt)

Ceramic Matrix Material

3) Metal Waste

i) Fission Products

plus Uranium

made up of:

a) Uranium

$0.0856 \mathrm{~kg} / \mathrm{GW}-\mathrm{hr}_{e}$

b) Rare Earths $\quad 0.031 \mathrm{~kg} / \mathrm{GW}-\mathrm{hr}_{e}$

c) Noble Metals $\quad 0.046 \mathrm{~kg} / \mathrm{GW}-\mathrm{hr}_{e}$

ii) Hardware and $\quad 1.061 \mathrm{~kg} / \mathrm{GW}-\mathrm{hr}_{e}$

Process Waste

made up of:
a) $\mathrm{Zr}$ (Alloy $\mathrm{Zr}$ )
$0.188 \mathrm{~kg} / \mathrm{GW}-\mathrm{hr}_{e}$
b) Cadmium
$0.0824 \mathrm{~kg} / \mathrm{GW}-\mathrm{hr}_{e}$
c) Chopped
Cladding Hulls $\quad 0.791 \mathrm{~kg} / \mathrm{GW}-\mathrm{hr}_{e}$ 
8CBNARIO 1 - IFRS On1Y

(All Mass Flows in $\mathrm{kg} / \mathrm{GW}$-hre)

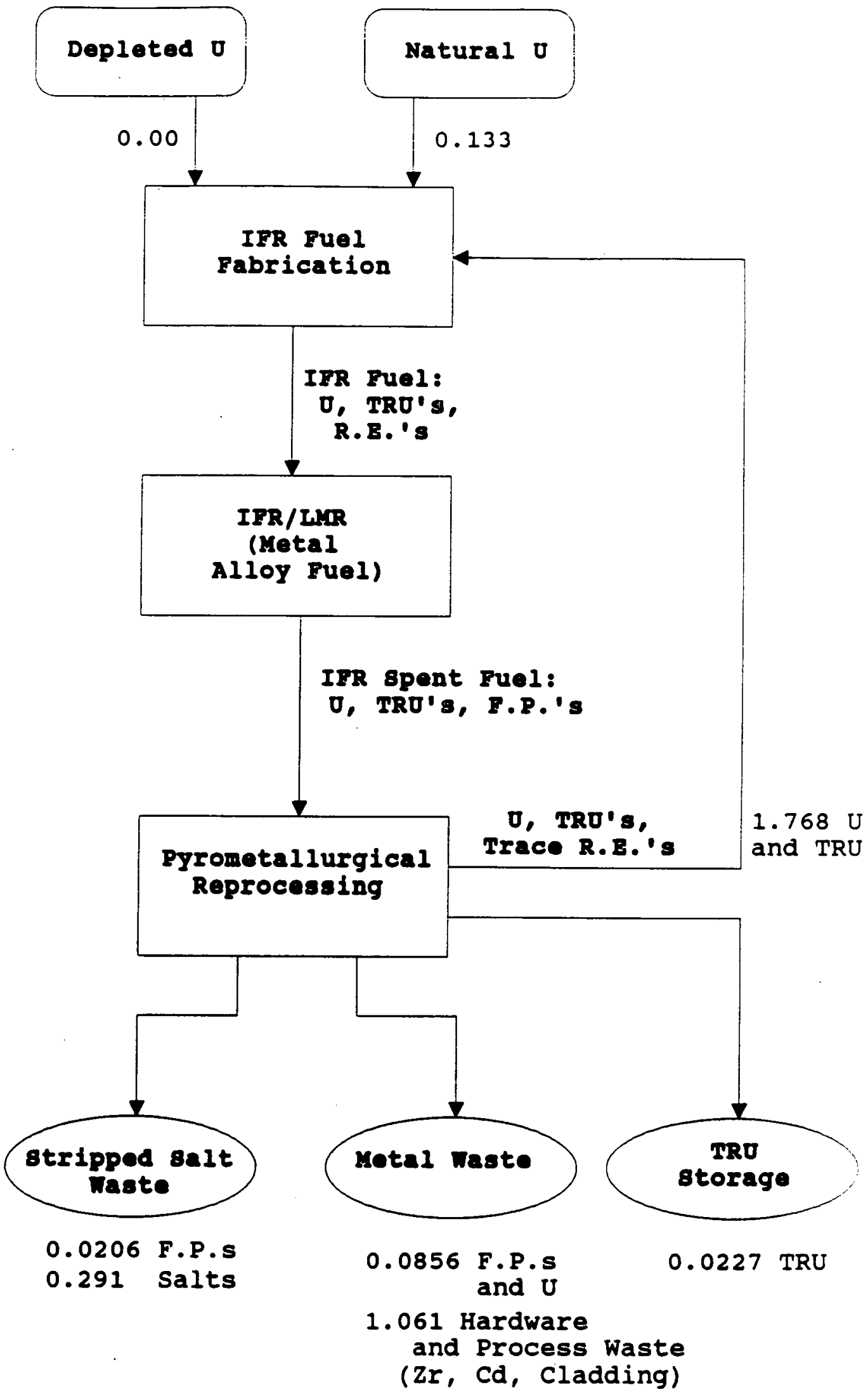

Figure 4-4: Scenario 1 Flowsheet with Mass Flows

(IFRs Only) 
designed to use natural uranium as makeup feed for the fuel fabrication process. An effort should be made to determine how this IFR design would run using depleted uranium fuel. Possibly the IFR could make use of the vast stockpiles of depleted uranium around the country, thereby reducing the magnitude of a potential large low-level radioactive waste problem.

Scenario 2

Scenario 2 involves the symbiotic union of thermal reactors (LWRs and MGRs) with IFRs used as actinide burners. The IFR Actinide Burner is used to burn not only its own actinides, but also those from the thermal reactor spent fuel as well. The input and output mass flows for Scenario 2 are tabulated in Table 4-2. The mass flows are also presented graphically on the Scenario 2 flowsheet in Figure 4-5.

Scenario 2 represents a Combined Hybrid System (CHS) which takes advantage of the best qualities of both reactor types, providing the operability and safety of the thermal reactors with the waste processing and actinide burning properties of the IFR. As shown in Table 4-2 and calculated in Appendix B, the Reactor Power Support Ratio of thermal reactors to IFRs is 3.01:1. Therefore in this Combined Hybrid System (CHS) for each 1.00 $\mathrm{GW}-\mathrm{hr}_{e}$ produced by the CHS, $0.751 \mathrm{GW}-\mathrm{hr}_{e}$ will be produced by thermal reactors, and $0.249 \mathrm{GW}-\mathrm{hr}_{e}$ will be produced by IFRs. Therefore, there will be roughly three LWR or MGR thermal reactors for each one IFR, assuming equal electric power output per reactor. Hence, a relatively large number of IFRs would be needed to burn the transuranics. Further 
Table 4-2: Scenario 2 Input and Output Mass Flows (Thermal Reactors with IFRs as Actinide Burners)

Basis: $\quad$ LWR Thermal Reactor

PWR Westinghouse $17 \times 17$

Efficiency $=0.337$

Burnup = 33,000 MWd/MTHM

Enrichment (fuel) $=3.1 \mathrm{wt} \%$ U-235

(tails) $=0.2 \mathrm{wt} \% \mathrm{U}-235$

Cooling time (before processing) $=3.17$ years

IFR Actinide Burner

Actinides

IFR Self Sufficient Reactor

Rating $=450 \mathrm{MW}_{e}\left(1157 \mathrm{MW}_{t h}\right)$

Breeding Ratio $=1.171$

Efficiency $=0.389$

Capacity Factor $=0.89$

Fission Products

IFR Self Sufficient Reactor

Rating $=389 \mathrm{MW}_{e}\left(1000 \mathrm{MW}_{t h}\right)$

Breeding Ratio $=1.0$

Efficiency $=0.389$

Capacity Factor $=0.89$

Power Ratio between the LWR Thermal Reactor and the IFR is:

\subsection{GW-hr LWR Thermal Reactor \\ $1.00 \mathrm{GW}-\mathrm{hr}_{e}$ IFR}

All mass flows calculated on a per $\mathrm{GW}-\mathrm{hr}_{e}$ generated by the Combined Hybrid System $\left(\mathrm{kg} / \mathrm{GW}-\mathrm{hr}_{e}\right.$ CHS).

Note:

$$
\begin{array}{ll} 
& \left(0.751 \mathrm{GW}-\mathrm{hr}_{e} \text { LWR Thermal Reactor }\right) \\
+\quad & \left(0.249 \mathrm{GW}-\mathrm{hr}_{e} \mathrm{IFR}\right) \\
= & 1.000 \mathrm{GW}-\mathrm{hr}_{e} \mathrm{CHS}
\end{array}
$$


Table 4-2 (continued): Scenario 2 Input and Output Mass Flows (Thermal Reactors with IFRs as Actinide Burners)

Flows:

A) Input:

1) Natural Uranium

$16.00 \mathrm{~kg} / \mathrm{GW}-\mathrm{hr}_{e} \mathrm{CHS}$

B) Output:

1) Depleted Uranium

$13.14 \mathrm{~kg} / \mathrm{GW}-\mathrm{hr}_{e}$ CHS

2) Reprocessed Uranium

$2.68 \mathrm{~kg} / \mathrm{GW}-\mathrm{hr} r_{e} \mathrm{CHS}$ contributions from:

i) Thermal Reactor

$2.68 \mathrm{~kg} / \mathrm{GW}-\mathrm{hr}_{e}$ CHS

ii) IFR

$4.89 \times 10^{-5} \mathrm{~kg} / \mathrm{GW}-\mathrm{hr}_{e} \mathrm{CHS}$

3) Noble Metal Fission Products

$3.62 \times 10^{-2} \mathrm{~kg} / \mathrm{GW}-\mathrm{hr}_{e}$ CHS (from LWR Thermal Reactor)

4) Gaseous Fission Products (from LWR Thermal Reactor)

$1.64 \times 10^{-2} \mathrm{~kg} / \mathrm{GW}-\mathrm{hr}_{e} \mathrm{CHS}$

5) Hardware

(from LWR Thermal Reactor)

$1.27 \mathrm{~kg} / \mathrm{GW}-\mathrm{hr}_{e}$ CHS

6) TRU

(transferred to IFR

from LWR Thermal Reactor) made up of:
i) $\mathrm{Np}$
$1.52 \times 10^{-3} \mathrm{~kg} / \mathrm{GW}-\mathrm{hr}_{e}$ CHS
ii) $\mathrm{Pu}$
$2.51 \times 10^{-2} \mathrm{~kg} / \mathrm{GW}-\mathrm{hr}_{e} \mathrm{CHS}$
iii) $\mathrm{Am}$
$1.41 \times 10^{-3} \mathrm{~kg} / \mathrm{GW}-\mathrm{hr}_{e}$ CHS
iv) $\mathrm{Cm}$
$1.74 \times 10^{-4} \mathrm{~kg} / \mathrm{GW}-\mathrm{hr}_{e}$ CHS 
Table 4-2 (continued): Scenario 2 Input and Output Mass Flows (Thermal Reactors with IFRs as Actinide Burners)

B) Output (continued)

7) Fission Products

(transferred to IFR

$5.33 \times 10^{-2} \mathrm{~kg} / \mathrm{GW}-\mathrm{hr}_{e} \mathrm{CHS}$

from LWR Thermal Reactor)

made up of:

i) Alkali Metals

$8.26 \times 10^{-3} \mathrm{~kg} / \mathrm{GW}-\mathrm{hr}_{e}$ CHS

ii) Alkaline Earths

$7.24 \times 10^{-3} \mathrm{~kg} / \mathrm{GW}-\mathrm{hr}_{e}$ CHS

iii) Rare Earths

$3.02 \times 10^{-2} \mathrm{~kg} / \mathrm{GW}-\mathrm{hr}_{e}$ CHS

iv) Halides

$6.71 \times 10^{-4} \mathrm{~kg} / \mathrm{GW}-\mathrm{hr} r_{e} \mathrm{CHS}$

v) Other Fission Products

$6.98 \times 10^{-3} \mathrm{~kg} / \mathrm{GW}-\mathrm{hr}_{e} \mathrm{CHS}$

Note: Noble Metals and Gaseous Fission Products are accounted for in item 3) and 4).

8) Stripped Salt Waste

Fission Products contributions from:

i) Thermal Reactor

$2.83 \times 10^{-2} \mathrm{~kg} / \mathrm{GW}-\mathrm{hr}_{\boldsymbol{e}}$

ii) IFR

$2.32 \times 10^{-2} \mathrm{~kg} / \mathrm{GW}-\mathrm{hr}_{e}$ CHS

$5.13 \times 10^{-3} \mathrm{~kg} / \mathrm{GW}-\mathrm{hr}_{e} \mathrm{CHS}$

made up of:

i) Alkali Metals

$1.15 \times 10^{-2} \mathrm{~kg} / \mathrm{GW}-\mathrm{hr}_{e} \mathrm{CHS}$

ii) Alkaline Earths

$8.80 \times 10^{-3} \mathrm{~kg} / \mathrm{GW}-\mathrm{hr}_{e}$ CHS

iii) Halides

$1.00 \times 10^{-3} \mathrm{~kg} / \mathrm{GW}-\mathrm{hr}_{e}$ CHS

iv) Other Fission Products

$6.98 \times 10^{-3} \mathrm{~kg} / \mathrm{GW}-\mathrm{hr}_{e}$ CHS

Plus: - Salts

$0.291 \mathrm{~kg} / \mathrm{GW}-\mathrm{hr}_{e}$ CHS

( $\mathrm{LiCl}$ Process Salt plus $\mathrm{NaCl}$ Bond Salt)

- Ceramic Matrix Material 
Table 4-2 (continued): Scenario 2 Input and Output Mass Flows (Thermal Reactors with IFRs as Actinide Burners)

B) Output (continued)

9) Metal Waste

i) Fission Products plus Uranium contributions from:

a) Thermal Reactor

b) IFR made up of:

a) Uranium

b) Rare Earths

c) Noble Metals

ii) Hardware and Process Waste (from IFR) made up of:

a) $\mathrm{Zr}$ (Alloy $\mathrm{Zr}$ )

b) Cadmium

c) Chopped Cladding Hulls
$5.15 \times 10^{-2} \mathrm{~kg} / \mathrm{GW}-\mathrm{hr}_{e}$ CHS

$3.02 \times 10^{-2} \mathrm{~kg} / \mathrm{GW}-\mathrm{hr}_{e}$ CHS

$2.13 \times 10^{-2} \mathrm{~kg} / \mathrm{GW}-\mathrm{hr}_{e} \mathrm{CHS}$

$2.13 \times 10^{-3} \mathrm{~kg} / \mathrm{GW}-\mathrm{hr}_{e} \mathrm{CHS}$

$3.79 \times 10^{-2} \mathrm{~kg} / \mathrm{GW}-\mathrm{hr}_{e} \mathrm{CHS}$

$1.15 \times 10^{-2} \mathrm{~kg} / \mathrm{GW}-\mathrm{hr}_{\boldsymbol{e}} \mathrm{CHS}$

$0.264 \mathrm{~kg} / \mathrm{GW} \cdot \mathrm{hr}_{e} \mathrm{CHS}$

$0.0468 \mathrm{~kg} / \mathrm{GW}-\mathrm{hr}_{e}$ CHS

$0.0205 \mathrm{~kg} / \mathrm{GW}-\mathrm{hr}_{e}$ CHS

$0.197 \mathrm{~kg} / \mathrm{GW}-\mathrm{hr}_{e}$ CHS 


\section{BCENARIO 2 - Thermal Reactor with}

\section{IFR Actinide Burner}

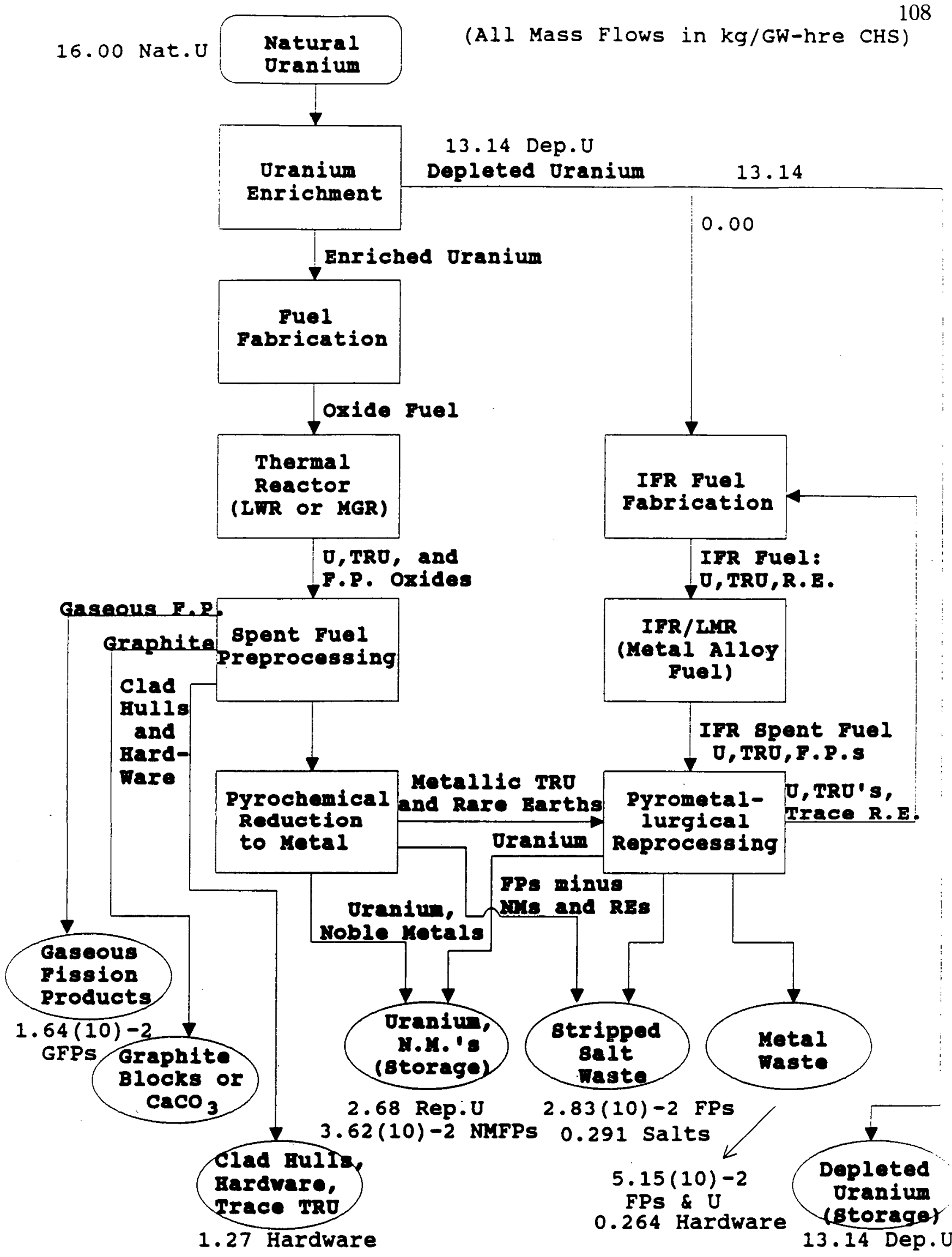

Figure 4-5: Scenario 2 Flowsheet with Mass Flows (Thermal Reactors with IFRs as Actinide Burners) 
work should be done to determine if the thermal reactor to IFR Power Ratio (3.01) can be increased. In this scenario, it is important to note that the noble metal fission products contained in the thermal reactor spent fuel end up being extracted in the reduction to metal process and chemically following the reprocessed uranium stream. The reprocessed uranium is intended to be stored for future use along with a substantial quantity of noble metal fission products. The public acceptance of this inadvertent extraction and storage of highly radioactive noble metal fission products from thermal reactor spent fuel is doubtful. This step requires additional work to investigate the possibility of removing the noble metals from this stream, and thereby, storing only clean uranium.

Scenario 3

Scenario 3 uses a thermal reactor combined with PUREX/TRUEX reprocessing to remove the actinide from the spent fuel, and yields a fission-product-only waste stream for geologic disposal. The input and output mass flows for Scenario 3 are tabulated in Table 4-3. The mass flows are also presented graphically on the Scenario 3 flowsheet in Figure 4-6.

This scenario is of interest because it represents what we could do now using proven current technology to remove the actinide isotopes from high-level radioactive waste before it is sent to a repository for geologic disposal. In this scenario, the actinides are removed from spent fuel without the use of the IFR pyrometallurgical reprocessing process. However, it must be noted that this scenario involves the storage of significant quantities of 
Table 4-3: Scenario 3 Input and Output Mass Flows (Thermal Reactors with PUREX/TRUEX Reprocessing)

Basis: $\quad$ LWR thermal reactor

$$
\begin{aligned}
& \text { PWR Westinghouse } 17 \times 17 \\
& \text { Efficiency }=0.337 \\
& \text { Burnup }=33,000 \mathrm{MWd} / \mathrm{MTHM} \\
& \text { Enrichment (fuel) }=3.1 \mathrm{wt} \% \text { U-235 } \\
& \text { (tails) }=0.2 \mathrm{wt} \% \mathrm{U}-235
\end{aligned}
$$

Flows:

$$
\text { All flows calculated on a per GW-hr } e \text { generated. }
$$
A) Input:

1) Natural Uranium

$21.3 \mathrm{~kg} / \mathrm{GW}-\mathrm{hr}_{\boldsymbol{e}}$

B) Output:

1) Depleted Uranium (0.2 wt \% U-235)

$17.5 \mathrm{~kg} / \mathrm{GW}-\mathrm{hr}_{\boldsymbol{e}}$

2) Reprocessed Uranium

$3.57 \mathrm{~kg} / \mathrm{GW}-\mathrm{hr}_{e}$

3) TRU (to storage) made up of:
i) $\quad \mathrm{Np}$
$2.025 \times 10^{-3} \mathrm{~kg} / \mathrm{GW}-\mathrm{hr}_{e}$
ii) $\mathrm{Pu}$
$3.338 \times 10^{-2} \mathrm{~kg} / \mathrm{GW}-\mathrm{hr}_{e}$
iii) $\mathrm{Am}$
$1.875 \times 10^{-3} \mathrm{~kg} / \mathrm{GW}-\mathrm{hr}_{e}$
iv) $\mathrm{Cm}$
$2.318 \times 10^{-4} \mathrm{~kg} / \mathrm{GW}-\mathrm{hr}_{e}$
Note: (Total F.P.s) - (Gaseous F.P.s) $=$
$0.1411 \mathrm{~kg} / \mathrm{GW}-\mathrm{hr}_{e}$
$0.1192 \mathrm{~kg} / \mathrm{GW}-\mathrm{hr}_{e}$
$0.0219 \mathrm{~kg} / \mathrm{GW}-\mathrm{hr}_{\boldsymbol{e}}$
$1.69 \mathrm{~kg}$ FA Hardware/GW-hr $\boldsymbol{e}_{\boldsymbol{e}}$

4) Fission Products

5) Fission Gases

6) Hardware 


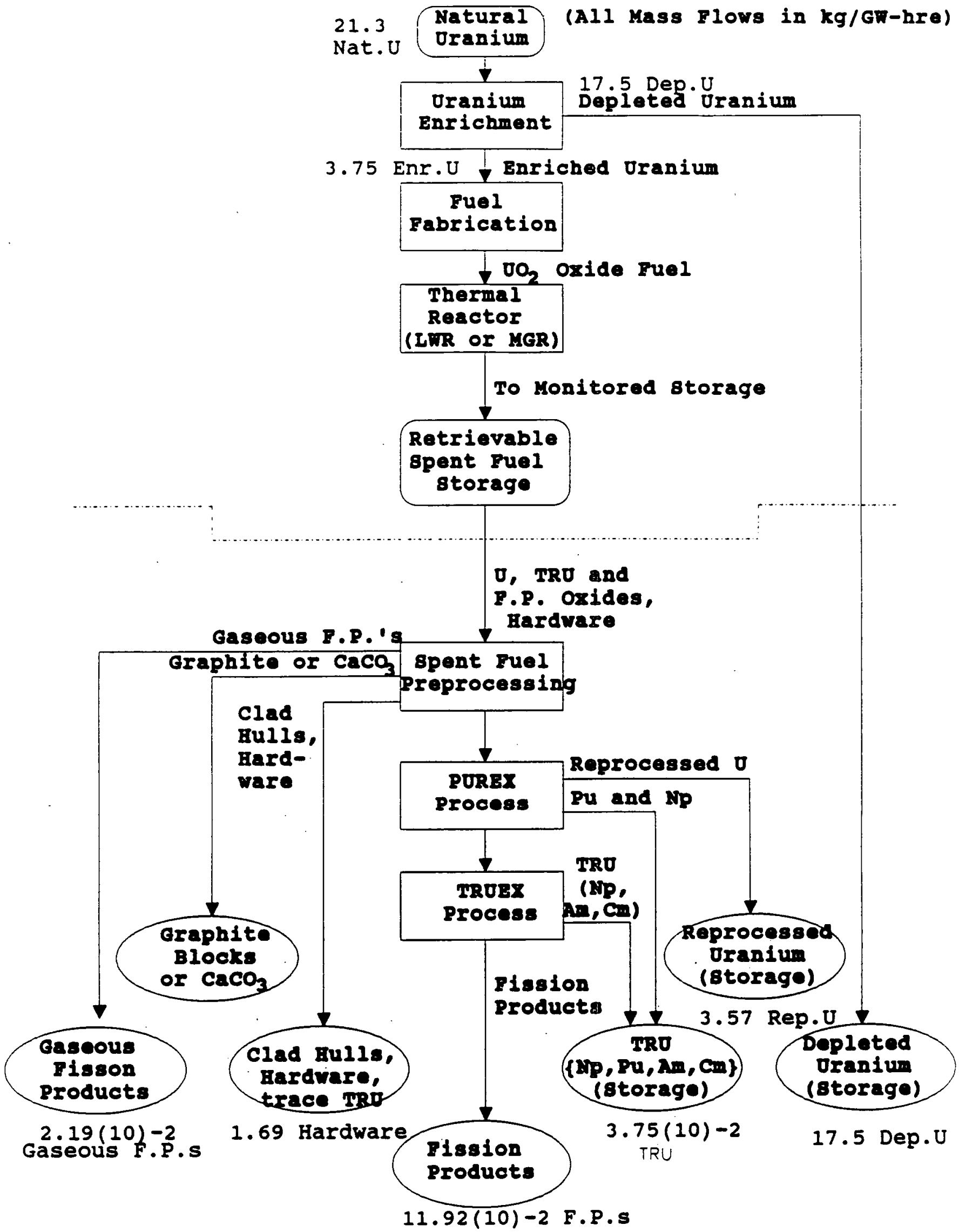

Figure 4-6: Scenario 3 Flowsheet with Mass Flows (Thermal Reactors with PUREX/TRUEX Reprocessing) 
reprocessed uranium and TRU isotopes with no clear answer or projection as to what is to be done with them. Finally, it is unclear as to whether the final waste form that the fission products are to be dispensed in, most likely borosilicate glass, is more or less robust and leach resistant than the copper matrix and ceramic matrix final waste forms used in the IFR process.

Note that the scenarios developed in this report represent steady state systems, and that therefore all of the calculations performed for each of the scenarios is done for a system at equilibrium. No attempt is made to address the transient aspect of each scenario, such as, the transient involved in going from the nuclear power system which currently exists in the United States to any one of the three steady-state scenarios analyzed in this report. This type of transient analysis is recognized as important, but the first goal of the work done for this project was to analyze a steady-state future case to address the long term feasibility of such systems. Transient analysis is a second order problem which is the next step which should be addressed after the analysis is done as a baseline to address the potential feasibility of the goals of actinide burning and the mitigation of the long-lived problem of high-level radioactive waste disposal. Therefore, this report does not account for or analyze the use of transuranic (TRU) isotopes extracted from thermal reactor spent fuel to provide the initial startup core for an IFR. Scientists at Argonne National Laboratory have calculated that the TRU isotopes contained in the yearly discharge from $171000 \mathrm{MW}_{e}$ LWRs could be used to make up one startup core for one $450 \mathrm{MW}_{e} \mathrm{IFR}$, or in energy related terms, the yearly TRU discharge from $37.8 \mathrm{MW}_{e}$ of LWR power could be used to 
provide the startup material for $1.00 \mathrm{MW}_{e}$ of IFR power [42]. The use of thermal reactor TRU isotopes to provide IFR startup cores may provide a significant use and mass flow of thermal reactor spent fuel actinides out of the waste stream. This transient process should be studied in more detail to determine its advantages and shortcomings.

Another issue which is not addressed directly by this report is the potential importance of long-lived fission product isotopes. There are seven important long-lived fission products:

C-14, Se-79, Zr-93, Tc-99, Pd-109, I-129, and Cs-135.

These long-lived fission product isotopes go directly into the waste steams in all three scenarios. This report does not give a breakdown of the mass flows for each isotope, but it is known which waste stream into which each of these fission product isotopes falls. In Scenario 1, the waste steams are the IFR Stripped Salt Waste Stream and Metal Waste Stream. The seven long-lived fission product isotopes apportion themselves chemically between these two waste steams as follows, I-129 and Cs-135 follow the Stripped Salt Waste Steam, and C-14, Se-79, Zr-93, Tc-99, and Pd-107 follow the Metal Waste Steam. Any residual actinides also follow the Metal Waste Stream. In Scenario 2, the combined thermal reactor and IFR Actinide Burner System, the IFR waste long-lived fission products follow the same steams as in Scenario 1, but for the thermal reactor LWR waste stream, the isotopes Tc-99 and Pd-107 follow the rest of the Noble Metals into the Reprocessed Uranium Output Stream, whereas the remaining long-lived fission products flow into the IFR process and follow the same waste streams as in Scenario 1, with I-129 and Cs-137 following the Stripped Salt Waste Stream and C-14, Se-79, and Zr-93 following the Metal Waste 
Stream. For Scenario 3, the thermal reactor using PUREX/TRUEX reprocessing, all of the non-gaseous fission products stay together in a single fission product waste stream. All seven long-lived fission product isotopes follow this stream in Scenario 3. More focused study on the mass flows and the importance of these long-lived fission products is necessary, and is planned as part of the follow-up research to be done after this report.

The calculational results of this report reveal a deficiency in some input data and process information. One example is the inconsistency between the assumptions (e.g. thermal power, electric power, thermal efficiency, and capacity factor) used in generating the actinide production data for the IFR, and the corresponding assumptions for the fission product generation data for the same IFR. Another example is the lack of full isotopic data for the spent fuel fission product yields from both the IFR and the LWR thermal reactor. Future research and reports should address this deficiency. 


\section{SECTION 5: SUMMARY, CONCLUSIONS, AND RECOMMENDATIONS FOR FUTURE WORK}

This report is a preliminary assessment of the role of actinide burning and the Integral Fast Reactor in the future of nuclear power. There are two primary reasons for undertaking this study of actinide partitioning and burning. The first is to help define a technology which could serve as a breakthrough for the long-term radiological safety and the public perception of high-level radioactive waste disposal. Second, finding a breakthrough in the high-level radioactive waste disposal issue is widely viewed as one of the prerequisites for the initiation of a large-scale next generation deployment of advanced nuclear power reactors in the United States. Safety, cost, waste management, and nuclear proliferation are the four primary impediments to the resurgence of nuclear power in this country. Safety and cost issues are being addressed by the designers of advanced reactor systems. The issues of high-level radioactive waste management and nuclear proliferation are the focus of this study. Nuclear proliferation and nuclear terrorism are inherently tied to the issue of highlevel waste management because both explicitly involve the back-end of the nuclear fuel cycle.

Section 2 of the report establishes the need for nuclear power generation in the future, which is, of course, a prerequisite for funding and constructing a next generation of nuclear power plants. Several energy/electricity demand forecasting models are analyzed. These models span the spectrum from anti-nuclear to pro-nuclear biases, and take into account environmental effects, primarily the greenhouse effect, as well as technological advances in and adoption of energy efficiency-measures. Also presented in Section 2 is a 
discussion of the potential obstacles and impediments to the future use of nuclear power, focused primarily on nuclear proliferation and nuclear terrorism.

This report intends to show how actinide partitioning and burning can be used in realistic future nuclear power scenarios. Section 3 outlines the assumptions used for developing these scenarios, and the reactor system and separation process technologies which are melded into the scenarios. The assumptions and ground rules which provide the boundary conditions for developing the scenarios are explicitly given. Three reactor systems are utilized in creating the future nuclear power scenarios: The Light Water reactor (LWR); the Modular Gas-Cooled Reactor (MGR); and the Integral Fast Reactor (IFR). Each of these alternative reactor systems is described in some detail in the report with specific emphasis given to high-level waste management and the back-end of the nuclear fuel cycle. Four processes for actinide separation and partitioning are used in building the future nuclear power scenarios: thermal reactor ceramic oxide spent fuel preprocessing, the PUREX process, the TRUEX process, and pyrometallurgical reprocessing. Each of these four actinide separation technologies is described in the report.

Section 4 of the report combines the reactor systems and the separation technologies into three nuclear power scenarios for the future using the boundary conditions developed in Section 3. The three scenarios are intended to present a broad spectrum of what could be done to partition and burn (fission) the actinide isotopes from nuclear power reactor spent fuel. A multitude of scenarios for nuclear power in the future are plausible, and the three scenarios analyzed in this report were therefore selected to represent the end-points of what can be done. Narrowing the number of scenarios to analyze is necessary to make 
the problem both addressable and understandable.

The first of the three scenarios involves only self-sustaining Integral Fast Reactors (IFRs). The IFRs separate out and burn as fuel their own actinides through an integral fuel cycle. This scenario represents a future in which all current generation Light Waste Reactors (LWRs) have been phased out and replaced by IFRs. Scenario 1 is illustrated in Figure 5-1.

The second scenario involves thermal reactor (either LWRs or Modular Gas-Cooled Reactors (MGRs)) combined with IFRs optimized for actinide burning (IFR-AB) in a Combined Hybrid System in which the two reactor types exist in symbiosis with each other, with the IFR-AB burning the actinide isotopes separated out from the thermal reactor spent fuel stream, as well as its own actinide. This scenario combines the best aspects of the thermal reactors (safety, cost, operability) and the IFR (actinide burning/waste management) into an appealing symbiotic system for future nuclear power. Scenario 2 is illustrated in Figure 5-2.

The third scenario involves thermal reactors (LWRs and/or MGRs) in conjunction with PUREX/TRUEX aqueous reprocessing used to separate the actinide isotopes out from the spent nuclear fuel waste stream before it is routed to ultimate disposal. This is not truly an actinide burning scenario, but can instead be thought of as an actinide partitioning and storage scenario, as no actinides are in the ultimate high-level radioactive waste disposal stream. This scenario is intended to represent what could be done today, using current technologies, to mitigate the long-lived problem of high-level radioactive waste. Scenario 3 is illustrated in Figure 5-3. 


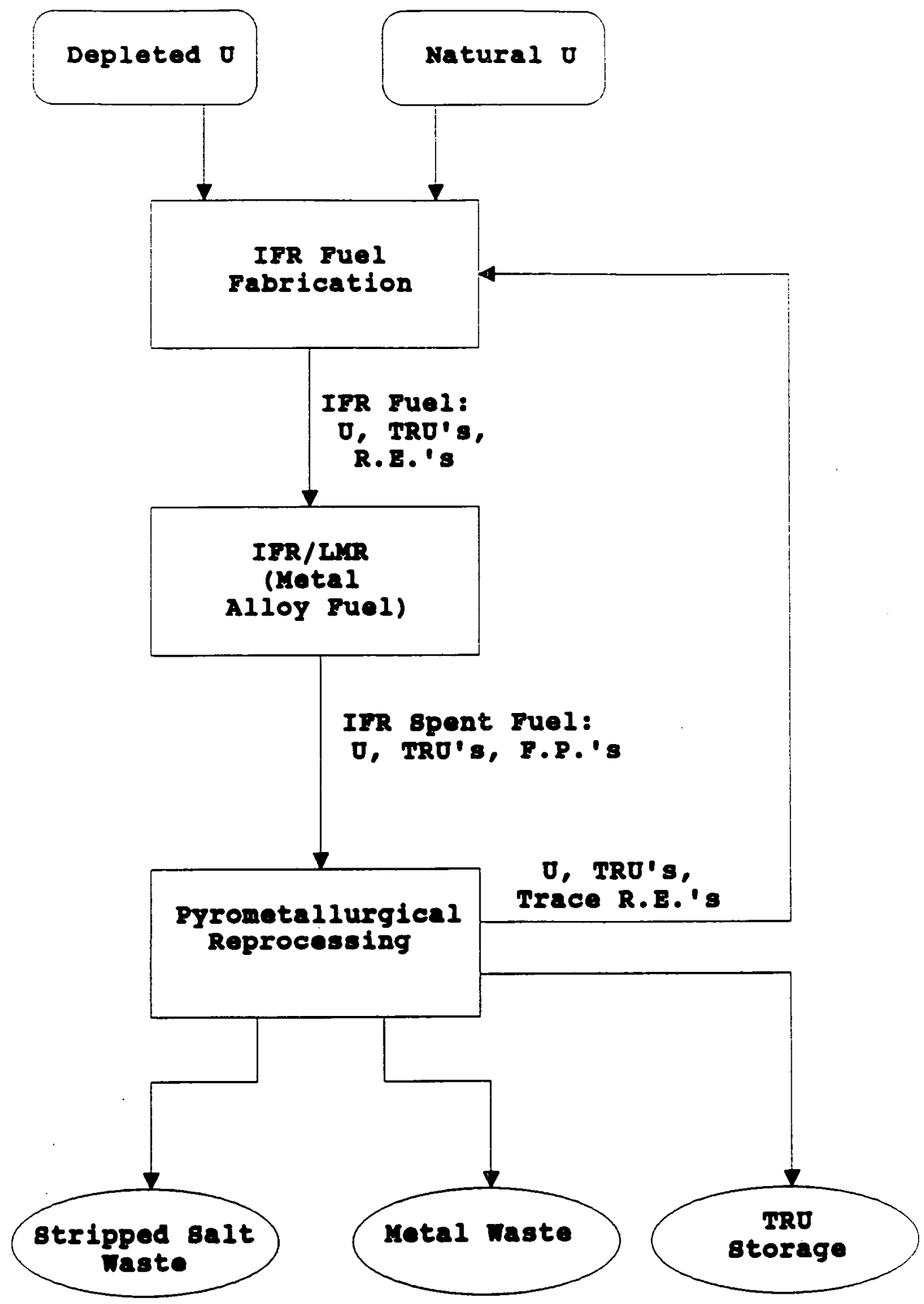

Figure 5-1: Scenario 1 Flowsheet (IFRs Only) 


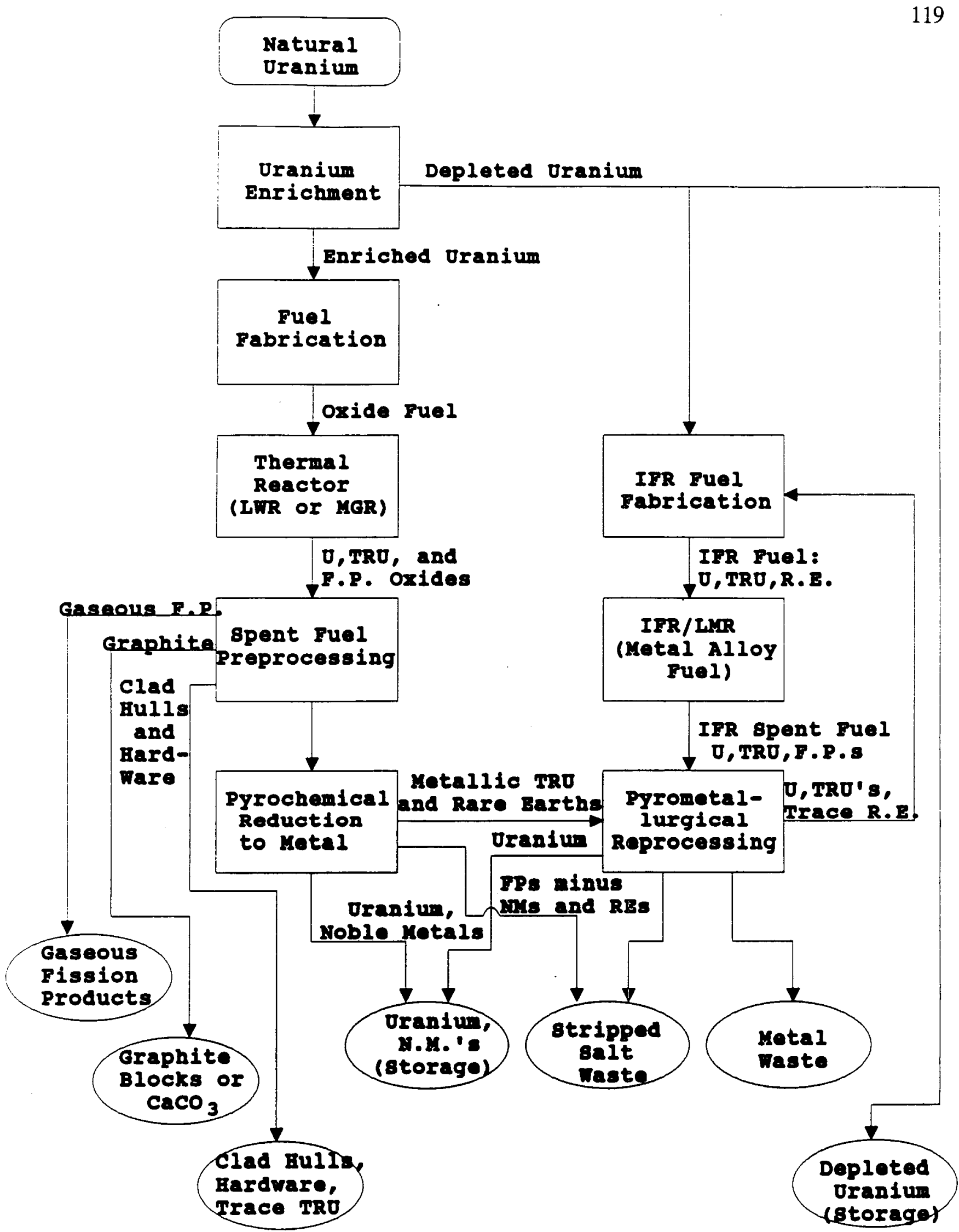

Figure 5-2: Scenario 2 Flowsheet (Thermal Reactors with IFRs as Actinide Burners) 
gCENARIO 3 - Thermal Reactor with

PUREX/TRUEX Reprocessing

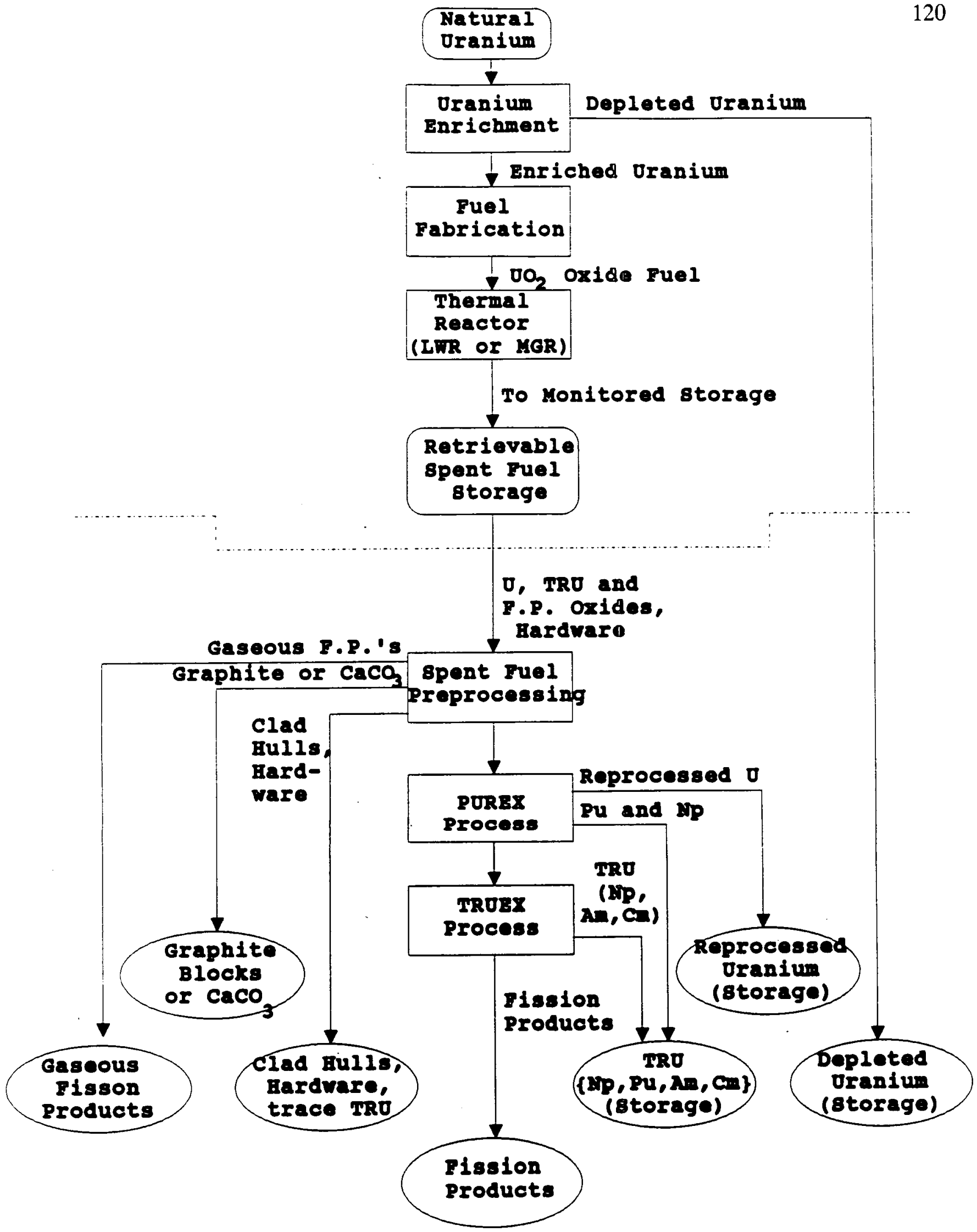

Figure 5-3: Scenario 3 Flowsheet (Thermal Reactors with

PUREX/TRUEX Reprocessing) 
The final subsection of Section 4 analyzes each of the three scenarios and determines the internal mass flows as well as the input and output stream mass flows for each scenario. All of the mass flows are calculated in units of $\mathrm{kg} / \mathrm{GW}-\mathrm{hr} r_{e}$, or mass per unit of electrical energy generated. These units allow the mass flows from the three scenarios to be compared on an equal basis by factoring out such variables as unit thermal power, thermal efficiency, and capacity factor. For the Combined Hybrid System (CHS) of Scenario 2, the reactor support ratio is calculated, in terms of "GW-hr $e_{e}$ thermal reactors/GW-hr $\mathrm{h}_{e} \mathrm{IFR}$," and all of the mass flows are given in units of $\mathrm{kg} / \mathrm{GW}-\mathrm{hr} r_{e}$ CHS (per each unit of electricity generated by the Combined Hybrid System in aggregate). The actual calculations and the calculational basis or each of the scenarios are given in Appendix A, Appendix B, and Appendix C.

A variety of conclusions can be made from this study. The first conclusion is that nuclear power, in some form, will be needed in the short term (50 year) future. All of the energy and electricity demand forecasting models analyzed, from the anti-nuclear biased models to the pro-nuclear biased models, predict that nuclear electricity generation will be needed in the future. Nuclear power is needed in the near future because of a combination of the pressures to reduce the use of fossil fuels, particularly coal, to ameliorate environmental impacts like the greenhouse effect, coupled with the relatively slow development of large-scale, dependable solar power and renewable electricity sources and the ultimately limited magnitude of energy efficiency improvements. The models do vary with respect to the magnitude of nuclear power which will be needed in the future. The future nuclear power capacity demand forecasts range from $460 \mathrm{GWe}$ of worldwide installed 
nuclear capacity, to $2000 \mathrm{GWe}$ installed capacity. Although the forecasts vary by a factor of four, it is most important to notice that each of the electricity demand forecasts predicts a significant installed capacity of nuclear power in the future. Section 2 of the report contains additional detail on this issue.

Another conclusion of this report is that the issues of nuclear proliferation and nuclear terrorism are important and require further analysis, and that both of these issues will definitely come under closer scrutiny as the technologies of actinide partitioning and actinide burning become more widely discussed and more important. Other potential obstacles to the future use of nuclear power, besides nuclear proliferation and terrorism, include poor public perception of nuclear power and public distrust of the nuclear power establishment. Section 2 of the report gives a more detailed discussion of these issues.

The conclusions from the three future nuclear power scenarios developed for this study are the internal mass flows and the ultimate input and output mass flow streams for each of the three scenarios, as calculated in Section 4 of the report. All of the mass flows are given in units of $\mathrm{kg} / \mathrm{GW}-\mathrm{hr}_{e}$ generated, and therefore give the mass flow in kilograms corresponding to each unit of electricity that is actually generated by the system depicted in each of the three scenarios. This provides a level playing field for comparison of the mass flows among the three scenarios. Each of the three scenarios uses natural uranium as its sole nuclear fuel input. The exact input flows is listed in the detailed mass flow tables in Section 4. The ultimate output flow streams for each of the scenarios is given in this section in simplified form as a major conclusion of this study. The output mass flows for 
each of the three scenarios are shown in Table 5-1 for Scenario 1, Table 5-2 for Scenario 2, and Table 5-3 for Scenario 3.

Two important recommendations for future work are made based on the results of this study. First, the Combined Hybrid System (CHS), involving thermal reactors in symbiosis with IFR actinide burners, developed in Scenario 2, appears to represent the best hope both for a renewal of nuclear power technology and a next generation of nuclear power in the future, and for jump-starting the nation's high-level radioactive waste management program. The CHS should be made the subject of an intensive research and development effort to ascertain the feasibility, advantages, and disadvantages of such a system. The U.S. Department of Energy's Office of Civilian Radioactive Waste Management and the developers of the Integral Fast Reactor at Argonne National Laboratory should be particularly interested in continued research focused on the CHS scenario. Second, the third scenario, in which thermal reactors (LWRs or MGRs) are combined with PUREX/TRUEX reprocessing to separate out actinide isotopes from the high-level radioactive waste stream may represent a solution to the nation's high-level waste problem, currently the disposal of spent Light Water Reactor fuel, using existing technologies and processes. This scenario should also be made the subject of an intensive research and development effort to uncover its feasibility, advantages, and disadvantages. This study could be done in parallel with the CHS study proposed above. The U.S. Department of Energy's Office of Civilian Radioactive Waste Management, the civilian Light Water Reactor industry, and the developers of the Modular Gas-Cooled Reactor should be particularly interested in continued research focused on this system. 
Table 5-1: Scenario 1 Output Mass Flows

(IFRs Only)

\section{Output Mass Flows}

1) TRU - Storage

$0.0227 \mathrm{~kg} / \mathrm{GW}-\mathrm{hr}_{\boldsymbol{e}}$ $(\mathrm{Np}, \mathrm{Pu}, \mathrm{Am}, \mathrm{Cm})$

2) Stripped Salt Waste

Fission Products

(Alkali Metals, Alkaline Earths,

$0.0206 \mathrm{~kg} / \mathrm{GW}-\mathrm{hr}_{e}$ Halides)

3) Metal Waste

i) Fission Products

$0.0856 \mathrm{~kg} / \mathrm{GW}-\mathrm{hr}_{e}$ plus Uranium

(Uranium, Rare Earths,

Noble Metals)

ii) Hardware and

Process Waste

$1.061 \mathrm{~kg} / \mathrm{GW}-\mathrm{hr}_{\boldsymbol{e}}$

(Alloy Zirconium, Cadmium,

Cladding Hulls) 
Table 5-2: Scenario 2 Output Mass Flows

(Thermal Reactors with IFRs as Actinide Burners)

\section{Output Mass Flows}

All mass flows calculated on a per $\mathrm{GW}-\mathrm{hr}_{e}$ generated by the Combined Hybrid System (kg/GW-hr $e$ CHS).

1) Depleted Uranium (100\% from LWR)

2) Reprocessed Uranium

(100\% from LWR; $0 \%$ from IFR)

3) Noble Metal Fission Products

(100\% from LWR)

4) Gaseous Fission Products

(100\% from LWR; IFR contribution currently unquantified)

5) Hardware

(100\% from LWR; IFR contribution currently unquantified)

6) Stripped Salt Waste

Fission Products

(Alkali Metals, Alkaline Earths, Halides)

( $82 \%$ from Thermal Reactor; $18 \%$ from IFR)

7) Metal Waste

i) Fission Products plus Uranium (Uranium, Rare Earths, Noble Metals) (59\% from Thermal Reactor; $41 \%$ from IFR)

ii) Hardware and Process Waste (Alloy Zirconium, Cadmium, Cladding Hulls) (100\% IFR)
$13.14 \mathrm{~kg} / \mathrm{GW}-\mathrm{hr}_{e}$ CHS

$2.68 \mathrm{~kg} / \mathrm{GW}-\mathrm{hr}_{e} \mathrm{CHS}$

$3.62 \times 10^{-2} \mathrm{~kg} / \mathrm{GW}-\mathrm{hr}_{e}$ CHS

$1.64 \times 10^{-2} \mathrm{~kg} / \mathrm{GW}-\mathrm{hr}_{\boldsymbol{e}}$ CHS

$1.27 \mathrm{~kg} / \mathrm{GW}-\mathrm{hr}_{e}$ CHS

$2.83 \times 10^{-2} \mathrm{~kg} / \mathrm{GW}-\mathrm{hr}_{e}$

$0.264 \mathrm{~kg} / \mathrm{GW}-\mathrm{hr}_{e} \mathrm{CHS}$

$5.15 \times 10^{-2} \mathrm{~kg} / \mathrm{GW}-\mathrm{hr}_{e} \mathrm{CHS}$

Power Ratio between the LWR Thermal Reactor and the IFR is:

3.01 GW-hr ${ }_{e}$ LWR Thermal Reactor

$1.00 \mathrm{GW}-\mathrm{hr}_{e}$ IFR 
Table 5-3: Scenario 3 Output Mass Flows (Thermal Reactors with PUREX/TRUEX Reprocessing)

\section{Output Mass Flows}

1) Depleted Uranium

2) Reprocessed Uranium

3) TRU (to storage) $(\mathrm{Np}, \mathrm{Pu}, \mathrm{Am}, \mathrm{Cm})$

4) Fission Products

(Total, includes fission gases)

5) Fission Gases

6) Hardware
$17.5 \mathrm{~kg} / \mathrm{GW}-\mathrm{hr}_{e}$

$3.57 \mathrm{~kg} / \mathrm{GW}-\mathrm{hr}_{e}$

$0.0375 \mathrm{~kg} / \mathrm{GW}-\mathrm{hr}_{\boldsymbol{e}}$

$0.1411 \mathrm{~kg} / \mathrm{GW}-\mathrm{hr}_{e}$

$0.0219 \mathrm{~kg} / \mathrm{GW}-\mathrm{hr}_{\boldsymbol{e}}$

$1.69 \mathrm{~kg}$ FA Hardware $/ \mathrm{GW}-\mathrm{hr}_{e}$ 
Other recommendations for future work include additional analysis of the nuclear proliferation/terrorism issue, particularly as it pertains to systems involved in the future nuclear power scenarios developed in this study. For example, the excess quantity of transuranic isotopes generated by the "self-sustaining" IFR involved in Scenario 1 (IFRs Only) may represent a significant nuclear terrorism or proliferation problem. In addition, the issue of IFR fuel performance with fuel containing a large percentage of minor actinide isotopes must be analyzed in detail both analytically and experimentally. On the same note, the pyroprocess proposed for reducing thermal reactor ceramic oxide fuel into a metallic form must also be analyzed in much greater detail, in order to assess the feasibility and performance of this process.

One issue which must be addressed is the importance of the long-lived fission products contained in spent fuel (C-14, Se-79, Zr-93, Tc-99, Pd-107, I-129, and Cs-135). The impact of these isotopes on the long-term radiological hazard presented by high-level waste must be investigated. As a minimum, the specific mass flows of each of these isotopes must be determined and the path which each follows through each scenario must be tracked.

This study represents a first step in determining, in a real world sense, the feasibility of actinide partitioning and actinide burning used to mitigate the long-lived problem of highlevel radioactive waste. As a longer-term objective, once the technical feasibility of this has been established, an analysis of the economics and costs involved should be undertaken to determine if actinide partitioning and burning is financially feasible. In addition, and analysis of the overall safety of such a system, in light of the increased short-term radiological risk 
imposed by partitioning, transporting, and storing radioactive isotopes, in order to determine is actinide partitioning and burning is a desirable option from the standpoint of overall safety. 


\section{REFERENCES}

1. This strategy was first formulated by E. Boulding et al. in: Carbon Dioxide Effects, Research and Assessment Program: Workshop on Environmental and Societal Consequences of a Possible $\mathrm{CO}_{2}$-Induced Climatic Change, Report 009, CONF7904143, U.S. Department of Energy, October 1980, pp. 79-103. It has since been "rediscovered" and advocated by many others. See, e.g., W.W. Kellog and R. Schware, Climate Change and Society, Consequences of Increasing Atmospheric Carbon Dioxide, Westview Press, Boulder, CO, 1981; S.H. Schneider and S.L. Thompson in The Global Possible: Development and the New Century, R. Repetto, Ed., Yale University Press, New Haven, CT, 1985, pp. 397-430; D.J. Rose, M.M. Miller, and C. Agnew, "Global Energy Futures and $\mathrm{CO}_{2}$-Induced Climate Change," MITEL Report No. 83-015, Massachusetts Institute of Technology, Energy Laboratory, MIT, Cambridge, Massachusetts, 1983.

2. For a book-length exposition of the potential for reducing energy demand while maintaining economic growth via greater efficiency of end-use, see J. Goldemberg, T.B. Johansson, A.K.N. Reddy, and R.H. Williams, Energy for a Sustainable World, Wiley Eastern Limited, 1988. For a useful summary of the potential for greater energy efficiency in the U.S., see W.U. Chandler, H.S. Geller and M.R. Ledbetter, Energy Efficiency: A New Agenda, the American Council for an Energy-Efficient Economy, Washington, D.C., 1988.

3. Although the extra investment associated with many energy-efficient devices gives an "internal rate of return" in excess of the opportunity cost of capital or the market rate of interest, the implicit discount rate tends to be very high for poor people who often do not have the money to invest in the future. This is the major impediment to increased use of more efficient end-use devices in the residential and transportation sectors, particularly in developing countries where a majority of the population is poor. For a good discussion of this point in the context of the costs of reducing demand vs. increasing energy supply in Brazil, see J. Goldemberg and R.H. Williams, "The Economics of Energy Conservation in Developing Countries: A Case Study for the Electrical Sector in Brazil," in Energy Sources: Conservation and Renewables, D. Hafemeister, H. Kelly and B. Levi, Eds., AIP Conference Proceedings No. 135, American Institute of Physics, New York, 1985, pp. 33-51.

4. A good (bad?) example is the fact that in constant (1982) dollars the cost of gasoline in the U.S. was $35 \%$ cheaper in 1988 compared to 1949 . Annual Energy Review 1988, DOE/EIA 0384(88), Energy Information Administration, Washington, D.C., p.151. In many Third World countries, kerosene and diesel fuel are subsidized, and there is little political will to remove such subsidies in the face of the street demonstrations that commonly greet any such attempts. 
5. J. Goldemberg and R.H. Williams, op. cit.; for a concise review of various proposed approaches see, R.H. Williams, "Innovative Approaches to Marketing Electric Efficiency," in Electricity: Efficient End-Use and New Generation Technologies, and Their Planning Implications, T.B. Johansson, B. Bodlund, and R.H. Williams, Eds., Lund University Press, Lund, Sweden, 1989, pp. 831-860.

6. This is not to imply that new supply will not be needed especially to raise the quality of life of poor people and to provide for population growth, particularly in developing countries. However, without significant improvements in the efficiency of energy production and use, the required rate of growth of energy supply will strain the resources available for capital investment--including that of the World Bank and the regional development banks--as well as the environment.

7. For a discussion of this point, see W.H. Chandler, "Assessing Carbon Emission Control Strategies: The Case of China," Climate Change, 13, pp. 241-265.

8. See, e.g., R.H. Williams and E.D. Larson, "Expanding Roles for Gas Turbines in Power Generation," in Electricity: Efficient End-Use and New Generation Technologies, and Their Planning Implications, T.B. Johansson, B. Bodlund, and R.H. Williams, Eds., Lund University Press, Lund, Sweden, 1989, pp. 503-551.

9. In the U.S., proved reserves of natural gas have fallen from a 1907 peak of 293 trillion $\mathrm{ft}^{3}$ to 187 trillion $\mathrm{ft}^{3}$ in 1987, while the most recent U.S. Geological Survey assessment of U.S. undiscovered, recoverable resources provide a mean estimate for 1980 of 594 trillion $\mathrm{ft}^{3}$ of natural gas. For coal, the U.S. Energy Information Administration has estimated that the demonstrated reserve base contained 475 billion short tons at the beginning of 1988 , and that the recovery rate from this base is at least 50\%. Annual Energy Review 1988, op. cit., p. 87. On an energy equivalent basis, the gas reserves and the coal reserves at $50 \%$ recovery and equal amounts of bituminous and lignite correspond to approximately 200 quads and 4,500 quads, respectively. Globally, proved reserves of natural gas and coal at the end of 1988 were 3,953.3 trillion cubic feet and 1,022,680 million tonnes, respectively. This corresponds to about 4,000 quads of gas and 25,000 quads of coal. British Petroleum (BP) Statistical Review of World Energy, The British Petroleum Company, London, July 1989 , pp. 20 and 24 . This reference does not give estimates for ultimately recoverable gas and coal resources. Obviously, these are much more speculative than reserve estimates. However, there is a consensus among energy experts that the coalto-gas resource ratio is greater than the corresponding reserve ratio. For example, W. Häfele et al. give coal and gas resource estimates of about 250,000 quads and 8,000 quads, respectively. W. Häfele et al., Energy in a Finite World, Vol. 1, Paths to a Sustainable Future, Prepared by the International Institute for Applied Systems Analysis (IIASA), Ballinger, Cambridge, MA, 1981. 
10. While there is a widespread consensus among energy analysts concerning the need for further RD\&D on solar energy technologies, e.g., photovoltaics and sustained biomass, this consensus does not extend to nuclear power. In general, environmentalists welcome the development of reactors with a higher degree of passive safety, but point to what in their view are the unsolved problem of how to dispose of radioactive waste and the link between nuclear power and the spread of nuclear weapons. From this perspective, especially given the premise of both efficiency improvements and environmentally-benign solar energy options, it would be unwise to reinvest in nuclear power as a response to the greenhouse warming problem until it can satisfy stringent criteria with regard to reactor safety, waste disposal, and nuclear proliferation. For a recent exposition of this view, see R.H. Williams and H.A. Feiveson, "How to Expand Nuclear Power Without Proliferation," Bulletin of the Atomic Scientists, April 1990, pp. 40-45.

11. J. Goldemberg et al., op. cit.

12. W. Häfele, "Global and Regional Energy Scenario for the Reduction of $\mathrm{CO}_{2}$ Emissions and the Role of Nuclear Power," IAEA/ANL International Workshop on Safety of Nuclear Installations of the Next Generation and Beyond, August 28-31, 1989, The Congress Hotel, Chicago, Illinois.

13. J.A. Edmonds and J.M. Reilly, "A Long-Term Global Energy-Economic Model of Carbon Dioxide Release from Fossil Fuel Use," Energy Economics 5(2): pp. 74-88, 1983.

14. The modifications include: (1) the use of three end-use sectors in all regions instead of one outside of OECD countries; (2) 5-year instead of 25-year time steps for model outputs; (3) the addition of energy related $\mathrm{CO}, \mathrm{CH}_{4}, \mathrm{~N}_{2} \mathrm{O}$, and $\mathrm{NO}_{x}$ emissions; modifications to the electric power generation, primary energy supply, energy demand, and GNP determination modules. However, as pointed out by Edmonds, the model's analytical framework, in common with all existing greenhouse gas emission models, remains deficient in many important respects, e.g., it is not capable of: (1) adequately addressing the penetration of new technologies; (2) consistently retiring and installing new capital stocks; (3) including the effects of greenhouse gas control strategies on capital investment and economic growth; and (4) addressing the interaction between activities in one sector, e.g., household energy use of traditional biomass fuels, and the consequent impacts on another, e.g., land-use. J.A. Edmonds, "A Second Generation Greenhouse Gas Emissions Model: Outline of Design and Approach," MIT Workshop on Energy and Environmental Modeling and Policy Analysis, July 31 - August $1,1989$. 
15. A discussion of the approach used to model electricity generation is given in Appendix A, pp. A-30 to A-32 of the EPA report. Briefly, the electricity source mix is driven mainly by the relative costs of delivered electricity. For solar and nuclear, these costs'are specified exogenously, and include assumptions about technological improvements and environmental costs. In the RCW and SCW scenarios the cost of delivered nuclear electricity in 1985 was taken to be 6.1 cents/kwh (1988 \$), increasing to 7.6 cents/kwh in 2050 and remaining at this price until 2100 . In the RCWP and SCWP scenarios the nuclear cost decrease from 6.1 cents/kwh in 1985 to 5.5 cents/kwh in 2050 and remain at this level until 2100 .

It is interesting to compare these costs with those of the Edmonds/Reilly base case as specified in: J. Edmonds and J. Reilly, The IEA/ORAU Long-Term Global Energy - $\mathrm{CO}_{2}$ Model: Personal Computer Version A84PC, Environmental Sciences Division Publication No. 2797, Oak Ridge National Laboratory, Oak Ridge, TN, December 1986. For example, nuclear costs in 2050 are 7.5 cents/kwh (1980 \$) in the E/R base case as compared with 5.4 cents/kwh and 3.9 cents/kwh (also in 1980 $\$$ ) in the RCW/SCW and RCWP/SCWP EPA scenarios, respectively. The lower nuclear costs lead to a higher nuclear share in the EPA scenarios, but the absolute amount of nuclear power is comparable in the two cases since total electricity is greater in the E/R base case, reflecting more efficient end-use in the EPA scenario. For example, in the RCWP scenario, total electricity delivered is $131.5 \mathrm{EJ}$, of which the nuclear share is $28.4 \mathrm{EJ}$ or $21.6 \%$. In the EIR base case, total electricity and the nuclear share are $177.2 \mathrm{EJ}$ and $27.4 \mathrm{EJ}$ for a nuclear share of $15.4 \%$.

16. J.B. Robinson, "Energy Backcasting: A Proposed Method of Policy Analysis," Energy Policy, December 1982, pp. 337-344.

17. For a good review of the subject with a focus on the reactor safety problem, see J.G. Marone and E.J. Woodhouse, The Demise of Nuclear Energy?, Yale University Press, New Haven, 1989.

18. The problem of lack of trust has been exacerbated by recent revelations about lax government standards at plants in the U.S. nuclear weapons complex dating from the Manhattan project which were concealed from the public.

19. However, there is also growing public dissatisfaction with the current strategy for disposing of low-level wastes; see, e.g., Scott Saleska, "Low-Level Radioactive Waste: Gamma Rays in the Garbage," Bulletin of the Atomic Scientists, April 1990, pp. 1825.

20. For example, Jose Goldemberg et al., John Holdren, Thomas Cochran, Terry Lash, Frank Von Hippel, and Amory Lovins. For a discussion of this point see, L.J. Carter, Nuclear Imperatives and Public Trust: Dealing with Radioactive Waste, Resources for the Future, Washington, D.C., p. 10. 
21. For a discussion of the rational for various hazard indices and time periods of concern, see, C.M. Koplik, M.F. Kaplan and B. Ross, "The Safety of Repositories for Highly Radioactive Wastes," Reviews of Modern Physics, Vol. 54, No. 1, 1982, pp. 272-276.

22. "Report to the American Physical Society by the Study Group on Nuclear Fuel Cycles and Waste Management," Reviews of Modern Physics, Vol. 50, No. 1, Part II, January 1978, pp. S109-S112; S114-S117.

23. The phrase is due to A. Wohlstetter et al., Swords from Plowshares, University of Chicago Press, 1979.

24. Indeed, the debate has already started, see, e.g., R.H. Williams and H.A. Feiveson, op. cit. ।

25. T.R. Johnson, R. Hill, L. Burns, and N. Levitz, "Use of Transuranic Elements from LWR Fuel in Advance Liquid Metal Reactors," Chemical Technology Division, Argonne National Laboratory, November 1989, Draft.

26. T.R. Johnson et al., op. cit., Table IV-12, p. 60.

27. T.R. Johnson et al., op. cit., Table IV-2, p. 30.

28. L. Baker, Jr., J.P. Burelbach, R.R. Heinrich, R.A. Marbach, and R.R. Rohde, "Security and Safeguards Assessment for a Commercial-Size IFR-Type Fuel Cycle Facility," Report No. ANL-IFR-38, Argonne National Laboratory, March 1986, Table 6-8, p. 53.

29. L. Baker, Jr. et al., op. cit., p. 57.

30. Office of the Federal Register, National Archives and Records Administration, Code of Federal Regulations, "Title 10: Energy, Part 61: Licensing Requirements for Land Disposal of Radioactive Waste," Washington D.C. (1987).

31. Public Law 97-425, "Nuclear Waste Policy Act of 1982," $97^{\text {th }}$ Congress of the United States, Washington, D.C. (January 1983).

32. R.A. Knief, Nuclear Energy Technology: Theory and Practice of Commercial Nuclear Power, McGraw-Hill Book Company (1981).

33. U.S. Department of Energy, Initial Version Dry Cask Storage Study, Washington, D.C., DOE/RW-0196 (August 1988). 
34. R.F. Turner, A.M. Baxter, O.M. Stansfield and R.E. Vollman, "Annular Core for the Modular High-Temperature Gas-Cooled Reactor (MHTGR)," Nuclear Engineering and Design, Volume 109 (February 1988).

35. M.G. Izenson, Effects of Fuel Particle and Reactor Core Design on Modular HTGR Source Terms, Ph.D. Thesis, M.I.T. Nuclear Engineering Department (February 1987).

36. U.S. Department of Energy, Characteristics of Spent Fuel, High-Level Waste, and Other Radioactive Wastes which May Require Long-Term Isolation, Washington, D.C., DOE/RW-0184 Volume 7 of 8 (June 1988).

37. A.J. Neylan, D.V. Graf and A.C. Millunzi, "The Modular High-Temperature GasCooled Reactor (MHTGR) in the U.S.," Nuclear Engineering and Design, Volume 109 (February 1988).

38. High Temperature Gas-Cooled Reactor Program, "An Assessment of the Interatom/KWU Modular HTGR Concept," principal contributors: Gas-Cooled Reactor Associates, Southern California Edison Co., General Electric Co., Combustion Engineering Inc., Bechtel Group Inc. (September 1985).

39. H. Reutler, "Plant Design and Safety Concept of the HTR-Module," Nuclear Engineering and Design, Volume 109, Volume 109 (February 1988).

40. C.E. Till and Y.I. Chang, "The Integral Fast Reactor," Advances in Nuclear Science and Technology, Volume 20 (1989).

41. Nucleonics Week-Special Report, "Outlook on Advanced Reactors; Sample Parameters for Some Advanced Reactors," Weekly Newsletter, McGraw-Hill (March 1985).

42. T.R. Johnson, L. Burris, N.M. Levitz, and R.N. Hill, "Use of Transuranic Elements From LWR Fuel in Integral Fast Reactors," IFR Technical Memorandum No. 127, ANL-IFR-127 (February 1990).

43. Y.I. Chang, "The Integral Fast Reactor," ANS Seminar Presentation at M.I.T. (March 1989).

44. C.D. Watson et al., "Mechanical Processing of Spent Power Reactor Fuel at Oak Ridge National Laboratory," Proceedings of the AEC Symposium for Chemical Processing of Irradiated Fuel From Power, Test, and Research Reactors, Report TID-7583, p.306 (January 1960). 
45. V.P. Kelly, "Final Report Shear Development for the Non-Production Fuels Reprocessing Program," Report HW-69667 (1961).

46. P.W. Smith, "The ZIRFLEX Process Terminal Development Report," Report HW65979 (August 1960).

47. F.D. Fisher, "The SULFEX Process Terminal Development Report," USAEC Report HW-66429 (August 1960).

48. $\quad$ R.E. Blanco, "Dissolution and Feed Adjustment," Symposium on the Reprocessing of Irradiated Fuels, Brussels, Belgium, USAEC Report TID-7534, Book 1, pp. 22-44 (May 1957).

49. L.H. Brooks, "Survey and Evaluation of Methods for Reprocessing Spent HTGR Fuel," Report GA-A12853.

50. A.G. Croff, "An Evaluation of Options Relative to the Fixation and Disposal of ${ }^{14} \mathrm{C}$ contaminated $\mathrm{CO}_{2}$ as $\mathrm{CaCO}_{3}$."

51. M. Izenson, "Effects on Fuel Particle and Reactor Core Design on Modular HTGR Source Terms," MIT Ph.D. Thesis (October 1986).

52. "Gas-Cooled Reactors Today, Volume 2: Advances in Fuel, Core, and Structural Materials," Proceedings of the British Nuclear Energy Society Conference, Bristol (September 1982).

53. D.T. Young, "Fluidized Combustion of Beds of Large, Dense Particles in Reprocessing HTGR Fuel," Report GA-A14327.

54. K.H. Lin, "Characteristics of Radioactive Waste Streams Generated in HTGR Fuel Reprocessing," Report ORNL/TM-5096.

55. J.C Warf, Article from the Journal of the American Chemical Society, 71: 2187 (1949).

56. M. Benedict, T.H. Pigford, and H.W. Levi, Nuclear Chemical Engineering, 2nd edition, McGraw-Hill (1981).

57. W.A. Rodger, "Reprocessing of Spent Nuclear Fuel," Presentation to the California Energy Resources Conservation and Development Commission (March 1977).

58. $\quad$ R.R. Jackson and R.L. Walser, "PUREX Process Operations and Performance," Report ARH-2127 (March 1977). 
59. A. Naylor, "TBP Extraction Systems - TBP and Diluent Degradation," Report KR126, p. 120 (1967).

60. B.L. Vondra, "LWR Fuel Reprocessing and Recycle Program," Quarterly Report for Report for Period October to December 1976, Report ORNL/TM-5760 (February 1977).

61. G.F. Vandegrift, E.P. Horwitz, et. al., "Transuranic Decontamination of Nitric Acid Solutions by the TRUEX Solvent Extraction Process - Preliminary Development Studies," Report ANL-84-45.

62. W.W. Schulz and E.P. Horwitz, "The TRUEX Process and the Management of Liquid TRU Waste," Separation Science and Technology, Vol. 23, pp. 12-13 (1988).

63. E.P. Horwitz, et. al., "TRU Decontamination of High-Level PUREX Waste by Solvent Extraction Using a Mixed Octyl(phenyl)-N1N1-diisobutyl Carbamoylmethyphosphine oxide/TBP/NPH (TRUEX) Solvent," Proceedings of the International Symposium on Actinide/Lanthanide Separations, p. 43 (1984).

64. G.F. Vandegrift, et. al., "Modeling of Aqueous and Organic Phase Speciation for Solvent Extraction Systems," (November 1988).

65. G.F. Vandegrift, et. al., "The Generic TRUEX Model," Proceedings of the Actinide Separation Conference (May 1988).

66. G.F. Vandegrift, et. al., "Thermodynamic Modeling of Chemical Equilibria in Metal Extraction," Separation Science and Technology, Vol. 23, pp. 12-13 (1988).

67. G.F. Vandegrift, et. al., "The Generic TRUEX Model Volume One - Operating - Manual for the Macintosh Version."

68. W.D. Bond, J.T. Bell, D.O. Campbell, and E.D. Collins, "ORNL Review of TRUEX Flow Sheet Proposed for Deployment at the Rockwell Hanford Plutonium Finishing Plant," Report ORNL/TM-1033 (1987).

69. T.R. Johnson, R. Hill, L. Burris, and N. Levitz, "Use of Transuranic Elements from LWR Fuel in Advanced Liquid Metal Reactors," Preprint (November 1989).

70. L. Burris, et. al., "A Proposed Pyrometallurgical Process for Rapid Recycle of Discharged Fuel Materials from the Integral Fast Reactor," from Fuel Reprocessing and Waste Management (August 1984).

71. $\quad$ L. Burris, et. al., "Spent Fuel from IFR is Renewed by Electrorefining Process." 
72. T.R. Johnson, M.A. Lewis, D.F. Fischer, and D.W. Warren, Seminar on Treatment of Pyroprocess Wastes (1989).

73. Y.I. Chang, Seminar Given at the Massachusetts Institute of Technology on the IFR (1989).

74. J.B. Knighton, I. Johnson, and R.K. Steunenberg, "Uranium Purification by the Process of Salt Transport," Report ANL-7524.

75. Public Service of Colorado, Final Safety Analysis Report for the Fort St. Vrain Reactor, Colorado (1988).

76. H.W. Graves, Jr., Nuclear Fuel Management, "Appendix C: Typical Nuclear Power Reactor Data," John Wiley \& Sons (1979).

77. U.S. Department of Energy, Office of Civilian Radioactive Waste Management, "Characteristics of Spent Fuel, High-Level Waste, and Other Radioactive Wastes Which May Require Long-Term Isolation - Appendix 2A: Physical Descriptions of LWR Fuel Assemblies," DOE/RW-0184, Volume 3 of 6, Washington, D.C. (December 1987). 
Appendix A: Mass Flow Calculations for: Scenario 1 - IFRs Only

Integral Fast Reactor (IFR) actinide and fission product waste production calculations based on Argonne National Laboratory IFR Report ANL-IFR-127 [42].

\section{Basis:}

Self Sustaining IFR:

$450 \mathrm{MW}_{\mathrm{e}}$

$1157 \mathrm{MW}_{\mathrm{th}}$

$\mathrm{n}_{\mathrm{th}}=0.389$

Capacity Factor $=89 \%$

Breeding Ratio $=1.171$

Compound System Doubling Time $=31.7$ yrs

Fuel Residence Time $=4 \times 325$ e.f.p.d.

- Need to determine the flow in $\mathrm{kg} / \mathrm{GW}-\mathrm{hr}$ of all actinides and fission products.

- First determine the electric power produced per year in $\mathrm{GW}-\mathrm{hr}_{\mathrm{e}}$.

- Extract the mass flow data in $\mathrm{kg} / \mathrm{yr}$.

- Divide the mass flows in $\mathrm{kg} / \mathrm{yr}$ by the power produced in $\mathrm{GW}-\mathrm{hr} \mathrm{e}_{\mathrm{e}} / \mathrm{Yr}$ to get the mass flows in $\mathrm{kg} / \mathrm{GW}-\mathrm{hr}_{\mathrm{e}} \cdot$.

\section{Power Produced Per Year:}

$450 \mathrm{MW}_{\mathrm{e}} \times \frac{1 \mathrm{GW}}{1000 \mathrm{MW}_{\mathrm{e}}} \times 0.89 \times \frac{365 \mathrm{~d}}{1 \mathrm{Yr}} \times \frac{24 \mathrm{hr}}{1 \mathrm{day}}=3508 \mathrm{GW}-\mathrm{hr}_{\mathrm{e}} / \mathrm{Yr}$ 
Actinide Mass Flows:

Data from ANL-IFR-127 [42] Table III-2: "Equilibrium Reactor Performance and Mass Flow for $450 \mathrm{MW}_{\mathrm{e}}$ Core."

Actinide Equilibrium

Isotope Loading (kg/yr)

$\mathrm{U}-234$

$U-235$

$\mathrm{U}-236$

$\mathrm{U}-238$

$\mathrm{Np}-237$

$\mathrm{Pu}-236$

$\mathrm{Pu}-238$

$\mathrm{Pu}-239$

$\mathrm{Pu}-240$

$\mathrm{Pu}-241$

$\mathrm{Pu}-242$

Am-241

Am-242

Am-2 43

Cm-242

Cm-243

Cm-244

Cm-245

Cm-246
0.736
2.26
1.85
$6.05(10)+3$
4.00
$2.68(10)-5$
4.06
$4.71(10)+2$
$1.24(10)+2$
$1.20(10)+1$
5.12
5.32
0.311
1.04
$1.44(10)-2$
$1.10(10)-2$
0.437
$9.49(10)-2$
$2.69(10)-2$

Equilibrium

Discharge (kg/yr)

0.675

1.32

1.82

$5.59(10)+3$

4.49

$4.65(10)-5$

4.41

$5.31(10)+2$

$1.40(10)+2$

$1.47(10)+1$

5.77

4.82

0.353

1.17

0.244

$1.30(10)-2$

0.527

0.107

$3.03(10)-2$
Net Gain

(Loss) / yr

(0.0609)

$(0.942)$

(0.0251)

$(4.65(10)+2)$

0.492

$1.97(10)-5$

0.353

$5.99(10)+1$

1. $57(10)+1$

2.71

0.65

$(0.493)$

$4.23(10)-2$

0.132

0.230

$1.95(10)-3$

$9.01(10)-2$

$1.21(10)-2$

$3.42(10)-3$ 
- Now divide the mass flows in $\mathrm{kg} / \mathrm{yr}$ by the power produced in $\mathrm{GW}-\mathrm{hr} \mathrm{e}_{\mathrm{e}} / \mathrm{Yr}$ to get the mass flows in $\mathrm{kg} / \mathrm{GW}-\mathrm{hr} \mathrm{e}_{\mathrm{e}}$.

- Power produced per year $=3508 \mathrm{GW}-\mathrm{hr}_{\mathrm{e}} / \mathrm{Yr}$

\begin{tabular}{|c|c|c|c|}
\hline $\begin{array}{l}\text { Actinide } \\
\text { Isotope }\end{array}$ & $\begin{array}{l}\text { Equilibrium } \\
\text { Loading } \\
\text { (kg/GW-hr })\end{array}$ & $\begin{array}{l}\text { Equilibrium } \\
\text { Discharge } \\
\text { (kg/GW-hr })\end{array}$ & $\begin{array}{l}\text { Net Gain } \\
\text { (Loss)/yr } \\
(\mathrm{kg} / \mathrm{GW}-\mathrm{hr} \text { ) }\end{array}$ \\
\hline $\begin{array}{l}\mathrm{U}-234 \\
\mathrm{U}-235 \\
\mathrm{U}-236 \\
\mathrm{U}-238 \\
\mathrm{~Np}-237 \\
\mathrm{Pu}-236 \\
\mathrm{Pu}-238 \\
\mathrm{Pu}-239 \\
\mathrm{Pu}-240 \\
\mathrm{Pu}-241 \\
\mathrm{Pu}-242 \\
\mathrm{Am}-241 \\
\mathrm{Am}-242 \\
\mathrm{Am}-243 \\
\mathrm{Cm}-242 \\
\mathrm{Cm}-243 \\
\mathrm{Cm}-244 \\
\mathrm{Cm}-245 \\
\mathrm{Cm}-246\end{array}$ & $\begin{array}{l}2.10(10)-4 \\
6.44(10)-4 \\
5.27(10)-4 \\
1.72 \\
1.14(10)-3 \\
7.64(10)-9 \\
1.16(10)-3 \\
0.134 \\
3.53(10)-2 \\
3.42(10)-3 \\
1.46(10)-3 \\
1.52(10)-3 \\
8.86(10)-5 \\
2.96(10)-4 \\
4.10(10)-6 \\
3.14(10)-6 \\
1.25(10)-4 \\
2.70(10)-5 \\
7.67(10)-6\end{array}$ & $\begin{array}{l}1.92(10)-4 \\
3.76(10)-4 \\
5.19(10)-4 \\
1.59 \\
1.28(10)-3 \\
1.33(10)-8 \\
1.26(10)-3 \\
0.151 \\
3.99(10)-2 \\
4.19(10)-3 \\
1.64(10)-3 \\
1.37(10)-3 \\
1.01(10)-4 \\
3.33(10)-4 \\
6.95(10)-5 \\
3.71(10)-6 \\
1.50(10)-4 \\
3.05(10)-5 \\
8.64(10)-6\end{array}$ & $\begin{array}{l}(1.74(10)-5) \\
(2.68(10)-4) \\
(7.15(10)-6) \\
(0.133) \\
1.40(10)-4 \\
5.62(10)-9 \\
1.01(10)-4 \\
1.71(10)-2 \\
4.47(10)-3 \\
7.72(10)-4 \\
1.85(10)-4 \\
(1.41(10)-4) \\
1.21(10)-5 \\
3.76(10)-5 \\
6.56(10)-5 \\
5.56(10)-7 \\
2.57(10)-5 \\
3.45(10)-6 \\
9.75(10)-7\end{array}$ \\
\hline $\begin{array}{l}\text { Total: } \\
\text { U } \\
\text { Np } \\
\text { Pu } \\
\text { Am } \\
\text { Cm } \\
\text { TRU }\end{array}$ & $\begin{array}{l}1.72 \\
1.14(10)-3 \\
0.175 \\
1.90(10)-3 \\
1.67(10)-4 \\
0.1782\end{array}$ & $\begin{array}{l}1.59 \\
1.28(10)-3 \\
0.198 \\
1.80(10)-3 \\
2.62(10)-4 \\
0.2013\end{array}$ & $\begin{array}{l}(0.133) \\
1.40(10)-4 \\
2.26(10)-2 \\
(9.13(10)-5) \\
9.63(10)-5 \\
0.0227\end{array}$ \\
\hline
\end{tabular}




\section{Input (feed):}

- From ANL-IFR-127 [42] Table III-6 "Comparison of IFR Fuel Cycle Components," the only make-up feed is $466 \mathrm{~kg} / \mathrm{yr}$ of $100 \%$ uranium. It is assumed that this is natural uranium feed (0.711\% U-235)

Input Feed

$466 \mathrm{~kg} / \mathrm{yr}$ Natural U

$3508 \mathrm{GW}-\mathrm{hr}_{\mathrm{e}} / \mathrm{Yr}$

$=0.133 \mathrm{~kg} / \mathrm{GW}-\mathrm{hr}_{\mathrm{e}}$

This compares with the total uranium quantity calculated in the previous table.

Net output

TRU isotopes totaling $0.0227 \mathrm{~kg} / \mathrm{GW}-\mathrm{hr}_{\mathrm{e}}$

Breakdown:

Total Np

Total Pu

Total Am

Total cm

$$
\begin{array}{cl} 
& 1.40(10)-4 \\
& 2.26(10)-2 \\
-9.13(10)-5 \\
\text { Total: } \frac{9.63(10)-5}{0.0227 \mathrm{~kg} / \mathrm{GW}-\mathrm{hr} \text { e output }}
\end{array}
$$

- Assume that the americium deficit in the input is made up by plutonium.

Therefore, the resulting net flow to TRU storage is:

$$
\begin{array}{ll}
\mathrm{Np} & 1.40(10)-4 \\
\mathrm{Pu} & 2.25(10)-2 \\
\mathrm{Am} & -0- \\
\mathrm{Cm} & \frac{9.63(10)-5}{\mathrm{~kg} / \mathrm{GW}-\mathrm{hr}_{\mathrm{e}} \text { to TRU storage }}
\end{array}
$$

- Now find out total outflow of fission products in $\mathrm{kg} / \mathrm{GW}-\mathrm{hr} \mathrm{r}_{\mathrm{e}}$. 


\section{Fission Products}

- From ANL-IFR-127 [42] Section V.C "IFR Fuel Processing," for a self sufficient IFR with an initial core made up of LWR materials (same assumption as for actinide flow calculations), but:

$$
\begin{aligned}
& \text { Power }=1000 \mathrm{MW}_{\mathrm{th}} \\
& \text { Breeding Ratio } \left.=1.0^{(\text {not }} 1157 \mathrm{MW}_{\mathrm{th}}\right) \\
& (\text { not } 1.171)
\end{aligned}
$$

Note that this is somewhat different than the earlier assumptions.

Assume the same capacity factor and efficiency:

$$
\begin{array}{ll}
\text { Efficiency }=0.389 & \text { therefore } 1000 \mathrm{MW}_{\mathrm{th}}=389 \mathrm{MW}_{\mathrm{e}} \\
\text { Capacity factor }=898 &
\end{array}
$$

- Using ANL-IFR-127 [42] Table V-2 "Material Flows in IFR Process" (units $\mathrm{kg} / \mathrm{Yr}$ ) which corresponds to Figure $\mathrm{V}-3$ "Pyrochemical Electrorefining Process for IFR Fuels" (IFR Process Flowsheet), the waste streams are:

\#12 Stripped Salt Waste.

\#13 Metal Waste.

Part 1. Fission Products (Waste Streams)

Stream \#13 Metal Waste contains (units: $\mathrm{kg} / \mathrm{Yr}$ ):

$\begin{array}{ll}\text { U } & 26 \\ \text { Pu } & -0 \\ \text { Other TRU } & -0 \\ \text { Alloy Zr } & 570 \\ \text { Rare Earths } & 94 \\ \text { Noble Metals } & 140 \\ & \\ \text { Plus } & \\ \text { Cadmium } & 250 \\ \text { Chopped cladding Hulls } & 2400^{*} \\ \text { Copper alloy to produce waste form }\end{array}$

* Note - Cladding hulls quantity is taken from the text of ANL-IFR127 [42]. 
Stream \#12 Stripped Salt contains (units: $\mathrm{kg} / \mathrm{yr}$ ) :

$\begin{array}{ll}\text { U } & -0 \\ \text { Alkali Metals } & 40 \\ \text { Alkaline Earths } & 19 \\ \text { Rare Earths } & -0 \\ \text { Halides } & 4 \\ \text { Salts - LiCl and NaCl } & 882^{*}\end{array}$

Licl is process salt from the electrorefining process; $\mathrm{NaCl}$ is bond salt made up of Na used to thermally bond the IFR fuel pins to the cladding combined with $\mathrm{Cl}$ from the electrorefining process.

* Note - The salt quantity calculations are based on data from ANLIFR-127 [42] Table V-10, "Canistered Solid High-Level Wastes from Pyroprocessing of IFR Fuels."

$$
\text { Ratio of } \frac{\text { Salt }}{\text { Fission Products }}=\frac{280}{20}=14: 1
$$

Salt Quantity $=14 \times(40+19+4)=882$

Plus Ceramic Matrix $=\frac{600}{20} \times$ Fission Prods $=30: 1$

Ceramic Matrix Quantity $=30 \times(40+19+4)=1890$

\section{Long-Lived Fission Products}

The long-lived fission products are distributed between the two waste streams.

In Stripped Salt Waste

I-129

Cs -135 \begin{tabular}{c} 
In Metal Waste \\
\hline $\mathrm{C}-14$ \\
Se-79 \\
Zr-93 \\
Tc-99 \\
Pd-107
\end{tabular}

Plus any residual actinides

Note: The ANL-IFR-127 [42] report does not contain the exact isotopic yield for each of the long-lived fission products. 
Part 2. Fission Product Waste Streams (in $\mathrm{kg} / \mathrm{GW}-\mathrm{hr} \mathrm{e}_{\mathrm{e}}$ )

389 MWe $\times \frac{1 \mathrm{GW}_{\mathrm{e}}}{1000 \mathrm{MW}_{\mathrm{e}}} \times 0.89 \times \frac{365 \mathrm{~d}}{1 \mathrm{yr}} \times \frac{24 \mathrm{hr}}{1 \mathrm{~d}}=3033 \frac{\mathrm{GW}-\mathrm{hr}_{\mathrm{e}}}{\mathrm{yr}}$

Note: $\quad \frac{\mathrm{kg} / \mathrm{yr}}{\mathrm{GW}-\mathrm{hr}_{\mathrm{e}} / \mathrm{Yr}^{-}}=\mathrm{kg} / \mathrm{GW}-\mathrm{hr}_{\mathrm{e}}$

Metal Waste

$\mathrm{U}$

Zr (Alloy $\mathrm{Zr}$ )

Rare Earths*

Noble Metals

Cadmium

Chopped

$$
\begin{aligned}
& 8.57(10)-3 \mathrm{~kg} / \mathrm{GW}-\mathrm{hr} r_{\mathrm{e}} \\
& 0.188 \mathrm{~kg} / \mathrm{GW}-\mathrm{hr} r_{\mathrm{e}} \\
& 0.031 \mathrm{~kg} / \mathrm{GW}-\mathrm{hr} r_{\mathrm{e}} \\
& 0.046 \mathrm{~kg} / \mathrm{GW}-\mathrm{hr} \mathrm{e}_{\mathrm{e}} \\
& 0.0824 \mathrm{~kg} / \mathrm{GW}-\mathrm{hr} \mathrm{r}_{\mathrm{e}} \\
& 0.791 \mathrm{~g} / \mathrm{GW}-\mathrm{hr} r_{\mathrm{e}}
\end{aligned}
$$

Ratio (to U)

$$
\begin{array}{r}
1.0 \\
21.9 \\
3.6 \\
5.4 \\
9.6 \\
92.3
\end{array}
$$

Plus

Copper Alloy to produce the Metal Waste Form $\sim 170$

* Note that $4.29(10)-3 \mathrm{~kg} / \mathrm{GW}-\mathrm{hr}$ of the rare earths contained in the IFR spent fuel are returned back to fuel fabrication along with the actinides.

\section{Stripped Salt Waste}

Ratio (to Halides)

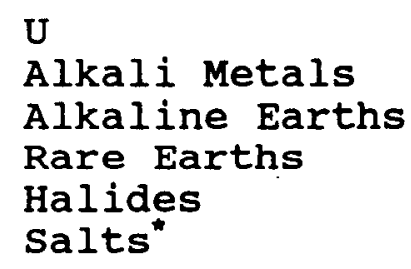

$$
\begin{aligned}
& -0 \mathrm{~kg} / \mathrm{GW}-\mathrm{hr} \\
& 0.013 \mathrm{~kg} / \mathrm{GW}-\mathrm{hr} \\
& 6.26(10)-3 \mathrm{~kg} / \mathrm{GW}-\mathrm{hr}_{\mathrm{e}} \\
& -0 \mathrm{~kg} / \mathrm{GW}-\mathrm{hr} r_{\mathrm{e}} \\
& 1.32(10)-3 \mathrm{~kg} / \mathrm{GW}-\mathrm{hr}_{\mathrm{e}} \\
& 0.291 \mathrm{~g} / \mathrm{GW}-\mathrm{hr}
\end{aligned}
$$$$
0.0
$$$$
10.0
$$$$
4.8
$$$$
0.0
$$$$
1.0
$$$$
70.0
$$

\section{* LiCl Process Salt plus NaCl Bond Salt}

Plus 
B. Assembly Hardware*

Assembly hardware is separated mechanically from the intact fuel rods and is packaged and disposed of separately. It is expected to be classified as a non-TRU greater than class $C$ Low Level Waste (i.e., not treated as High Level Waste).

C. Fission Gases*

Concentrated noble gases (krypton and xenon) are to be collected in the argon cell environment and stored until the $\mathrm{Kr}-85$ has decayed.

Tritium is to be stored in waste water until it has decayed to low levels.

* Note - Information is from the text of ANL-IFR-127 [42]. 
Appendix B: Mass Flow Calculations for:

Scenario 2 - Thermal Reactor with IFR Actinide Burner

Integral Fast Reactor (IFR) actinide and fission product waste production calculations based on Argonne National Laboratory IFR Report ANL-IFR-127 [42].

\section{Basis:}

IFR Reactor is different from Scenario 1.

a) Instead of being self Sufficient with a Breeding Ratio of 1.171, it is an Actinide Burner with a Breeding Ratio of 0.218 .

b) Instead of having blanket assemblies, The Actinide Burner IFR has stainless steel reflector assemblies.

New calculations will be done for actinide generation.

The same fission product and waste quantities calculated for Scenario 1 in Appendix $A$ will be used in lieu of further information from Argonne. These numbers will be somewhat incorrect because the fissile fuel for the Actinide Burner IFR will be a mix of LWR transuranics which differs from the fissile/fertile fuel used in the Self-Sustaining IFR analyzed in Appendix A. The assumption of using the numbers from the Self-Sustaining IFR is approximately valid because fission yield is somewhat independent of the parent actinide isotope.

Thermal Reactor data will be that generated in Scenario 3. See Appendix $C$ for their calculation.

The bases for the thermal reactor calculations are as follows:

LWR - PWR Westinghouse $17 \times 17$ Burnup $=33,000 \mathrm{MWd} / \mathrm{MTU}$

Enrichment (fuel) $=3.1$ wt $\%$ U-235 (tails) $=0.2$ wt $\%$ U-235

Efficiency $=33.7 \%$

Cooling Time $=3.17$ yrs (i.e., 1000 days) 


\section{Thermal Reactor}

\section{Mass Flows:}

(see Appendix $\mathrm{C}$ for basis and calculations for LWR Thermal Reactor mass flows)

A) Input (feed):
1) Natural Uranium
$21.3 \mathrm{~kg} / \mathrm{GW}-\mathrm{hr}_{\mathrm{e}}$

B) Output (waste):

1) Depleted Uranium

(0.2 wt $\%$ U-235)

$17.5 \mathrm{~kg} / \mathrm{GW}-\mathrm{hr} \mathrm{e}_{\mathrm{e}}$

2) Reprocessed Uranium

$3.57 \mathrm{~kg} / \mathrm{GW}-\mathrm{hr}_{\mathrm{e}}$

3) TRU

made up of:

i) $\mathrm{Np}$

$0.0375 \mathrm{~kg} / \mathrm{GW}-\mathrm{hr}_{\mathrm{e}}$

ii) $\mathrm{Pu}$

$2.025 \times 10^{-3} \mathrm{~kg} / \mathrm{GW}-\mathrm{hr}_{\mathrm{e}}$

iii) Am

$3.338 \times 10^{-2} \mathrm{~kg} / \mathrm{GW}-\mathrm{hr}_{\mathrm{e}}$

iv) $\mathrm{cm}$

$1.875 \times 10^{-3} \mathrm{~kg} / \mathrm{GW}-\mathrm{hr}_{\mathrm{e}}$

$2.318 \times 10^{-4} \mathrm{~kg} / \mathrm{GW}-\mathrm{hr}_{\mathrm{e}}$

4) Fission Products

(for further breakdown

$0.1411 \mathrm{~kg} / \mathrm{GW}-\mathrm{hr}_{\mathrm{e}}$ see next page)

Total Non-Gaseous F.P.s

$0.1192 \mathrm{~kg} / \mathrm{GW}-\mathrm{hr}_{\mathrm{e}}$

made up of:

i) Gaseous F.P.s

$0.0219 \mathrm{~kg} / \mathrm{GW}-\mathrm{hr}_{\mathrm{e}}$

ii) Noble Metals

$0.0482 \mathrm{~kg} / \mathrm{GW}-\mathrm{hr}_{\mathrm{e}}$

iii) (Total F.P.s)

- (Gaseous F.P.S)

- (Noble Metals)

$0.0710 \mathrm{~kg} / \mathrm{GW}-\mathrm{hr}_{\mathrm{e}}$

5) Hardware

$1.69 \mathrm{~kg}$ FA Hardware $/ \mathrm{GW}-\mathrm{hr}$ e 
Further Breakdown of Fission Product Yields

- Using ANL-IFR-127 [42] Table V-1 "Compositions of Product and Waste streams from Treatment of LWR Fuel in Pyrochemical Process):

LWR Fission Product Breakdown:

$\begin{array}{lrcr} & \text { kg/yr } & \begin{array}{l}\text { Resulting } \\ \text { Fraction }\end{array} & \text { Percent } \\ \text { Alkali Metals } & 1230 & 0.078 & 7.8 \% \\ \text { Alkaline Earths } & 1080 & 0.068 & 6.8 \% \\ \text { Rare Earths } & 4500 & 0.285 & 28.5 \% \\ \text { Noble Metals } & 5400 & 0.342 & 34.2 \% \\ \text { Halides } & 100 & 0.006 & 0.6 \% \\ \text { Fission Gases } & 2450 & 0.155 & 15.5 \% \\ \text { Other Fission Products } & 1040 & 0.066 & 6.6 \% \\ \text { Total } & 15800 & 1.000 & 100.0 \%\end{array}$

- From the previous page, item B.4, total fission products for the Thermal Reactor $=0.1411 \mathrm{~kg} / \mathrm{GW}-\mathrm{hr}_{\mathrm{e}}$

- Using the fractions calculated above, we can find the fission product breakdown.

Thermal Reactor Fission Products

$$
\mathrm{kg} / \mathrm{GW}-\mathrm{hr}
$$

$\begin{array}{ll}\text { Alkali Metals } & 0.0110 \\ \text { Alkaline Earths } & 0.00964 \\ \text { Rare Earths } & 0.0402 \\ \text { Noble Metals } & 0.0482 \\ \text { Halides } & 0.000893 \\ \text { Fission Gases } & 0.0219 \\ \text { Other Fission Products } & \underline{0.0093} \\ \text { Total } & 0.1411\end{array}$


II. IFR

Mass Flows:

IFR Fission Product Generation

- Fission product/waste data will be that calculated in Appendix A Scenario 1 with the caveats pointed out earlier about the applicability of these numbers.

- Includes IFR spent fuel contributions only

1) Stripped Salt Waste

Fission Product Total

$0.0206 \mathrm{~kg} / \mathrm{GW}-\mathrm{hr}_{\mathrm{e}}$

made up of:

i) Uranium

$\sim 0$

ii) Alkali Metals

$0.013 \mathrm{~kg} / \mathrm{GW}-\mathrm{hr}_{\mathrm{e}}$

iii) Alkaline Earths

$6.26 \times 10^{-3} \mathrm{~kg} / \mathrm{GW}-\mathrm{hr}_{\mathrm{e}}$

iv) Rare Earths

$-0$

v) Halides

$1.32 \times 10^{-3} \mathrm{~kg} / \mathrm{GW}-\mathrm{hr}_{\mathrm{e}}$

Plus:
salts
(LiCl Process salt plus NaCl Bond Salt)
Ceramic Matrix Material

2) Metal Waste
i) Fission Products
plus Uranium
$0.0856 \mathrm{~kg} / \mathrm{GW}-\mathrm{hr}_{\mathrm{e}}$
made up of:
a) Uranium
$8.57 \times 10^{-3} \mathrm{~kg} / \mathrm{GW}-\mathrm{hr}_{\mathrm{e}}$
b) Rare Earths
$0.031 \mathrm{~kg} / \mathrm{GW}-\mathrm{hr}_{\mathrm{e}}$
c) Noble Metals
$0.046 \mathrm{~kg} / \mathrm{GW}-\mathrm{hr}_{\mathrm{e}}$ 
2) Metal Waste (continued)
ii) Hardware and
Process waste
$1.061 \mathrm{~kg} / \mathrm{GW}-\mathrm{hr} \mathrm{e}_{\mathrm{e}}$
made up of:
a) $\mathrm{Zr}$ (Alloy $\mathrm{Zr}$ )
$0.188 \mathrm{~kg} / \mathrm{GW}-\mathrm{hr}_{\mathrm{e}}$
b) Cadmium
$0.0824 \mathrm{~kg} / \mathrm{GW}-\mathrm{hr} \mathrm{r}_{\mathrm{e}}$
C) Chopped
Cladding Hulls
$0.791 \mathrm{~kg} / \mathrm{GW}-\mathrm{hr} \mathrm{e}_{\mathrm{e}}$

\section{IFR Actinide Generation}

Basis: IFR Actinide Burner (called PUMAB by ANL)

(Data from ANL-IFR-127 [42] Table III-7 "Equilibrium Performance and Mass Flow for Plutonium-Minor Actinide Burner")

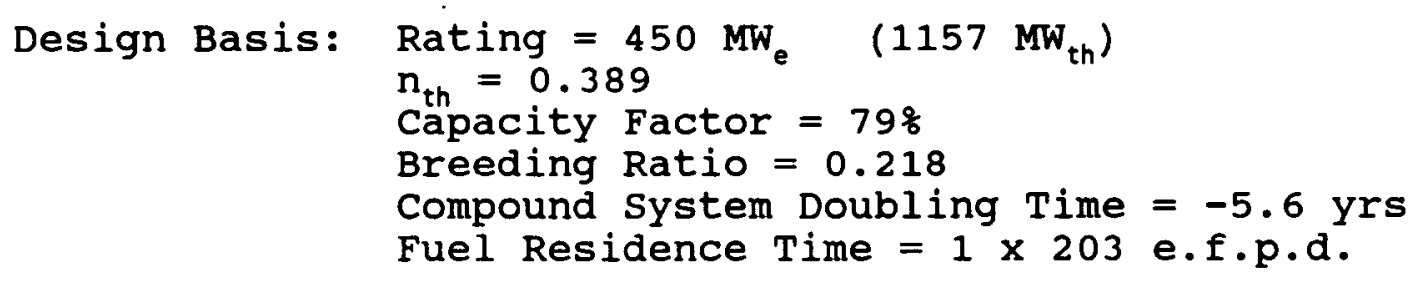

- Need to determine the flow in $\mathrm{kg} / \mathrm{GW}-\mathrm{hr}$ of all actinides and fission products.

- First determine the electric power produced per year in $G W-h r_{e}$.

- Extract the mass flow data in $\mathrm{kg} / \mathrm{yr}$.

- Divide the mass flows in $\mathrm{kg} / \mathrm{yr}$ by the power produced

in $\mathrm{GW}-\mathrm{hr}_{\mathrm{e}} / \mathrm{Yr}$ to get the mass flows in $\mathrm{kg} / \mathrm{GW}-\mathrm{hr}_{\mathrm{e}} \cdot$

\section{Power Produced Per Year:}

$450 \mathrm{MW}_{\mathrm{e}} \times \frac{1 \mathrm{GW}}{1000 \mathrm{MW}_{\mathrm{e}}} \times 0.79 \times \frac{365 \mathrm{~d}}{1 \mathrm{Yr}} \times \frac{24 \mathrm{hr}}{1 \text { day }}=3114 \mathrm{GW}-\mathrm{hr}_{\mathrm{e}} / \mathrm{Yr}$ 
IFR Actinide Mass Flows:

Data from ANL-IFR-127 [42] Table III-7: "Equilibrium Reactor Performance and Mass Flow for Plutonium-Minor Actinide Burner."

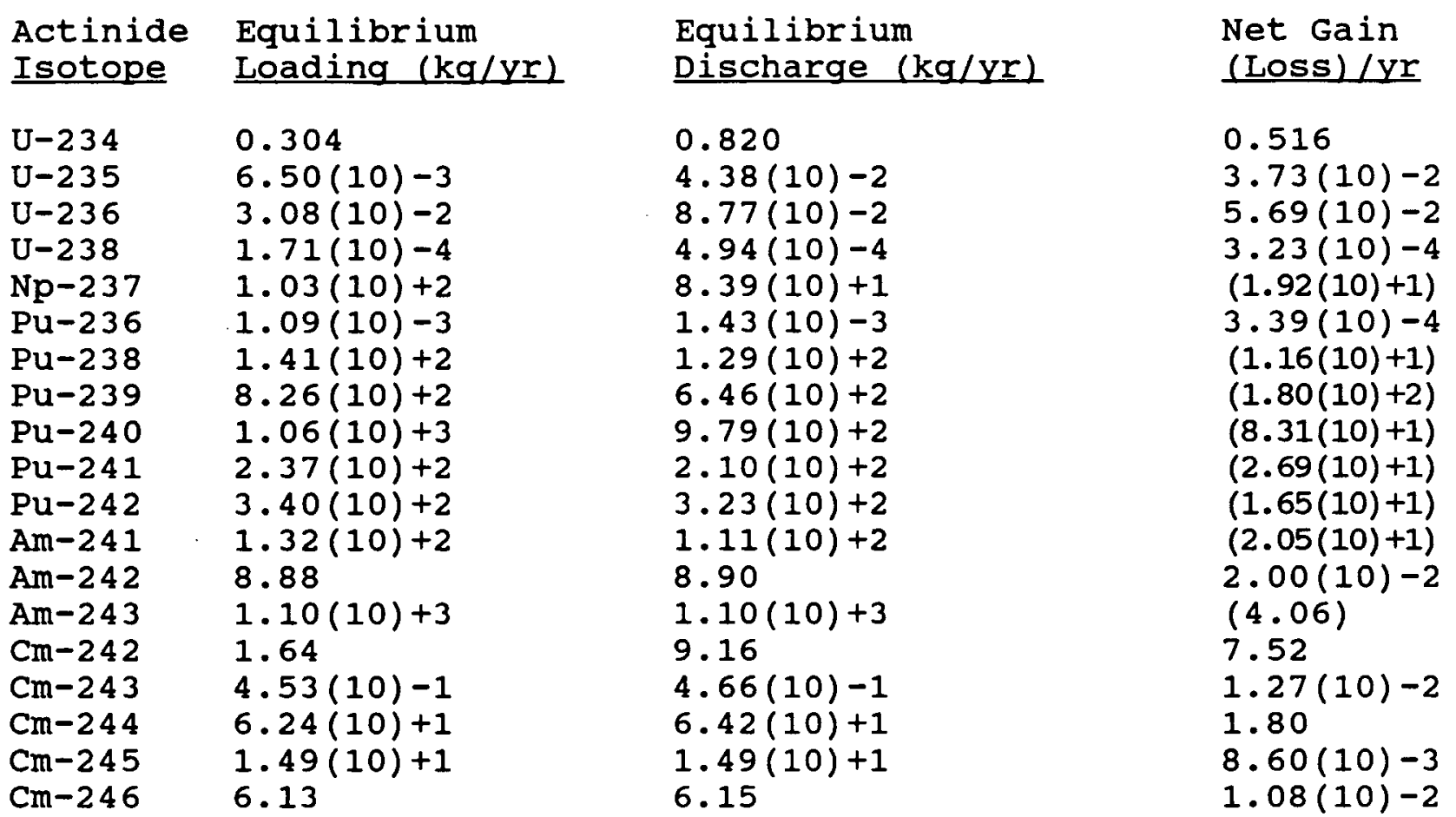


- Now divide the mass flows in $\mathrm{kg} / \mathrm{yr}$ by the power produced in $\mathrm{GW}-\mathrm{hr} \mathrm{e}_{\mathrm{e}} / \mathrm{Yr}$ to get the mass flows in $\mathrm{kg} / \mathrm{GW}-\mathrm{hr}_{\mathrm{e}}$.

- Power produced per year $=3114 \mathrm{GW}-\mathrm{hr} \mathrm{e}_{\mathrm{e}} / \mathrm{yr}$

\begin{tabular}{|c|c|c|c|}
\hline $\begin{array}{l}\text { Actinide } \\
\text { Isotope }\end{array}$ & $\begin{array}{l}\text { Equilibrium } \\
\text { Loading } \\
\text { (kg/GW-hre } / \mathrm{G}\end{array}$ & $\begin{array}{l}\text { Equilibrium } \\
\text { Discharge } \\
\text { (kg/GW-hre) }\end{array}$ & $\begin{array}{l}\text { Net Gain } \\
\text { (Loss)/Yr } \\
\text { (kg/GW-hr) }\end{array}$ \\
\hline $\begin{array}{l}U-234 \\
U-235 \\
U-236 \\
U-238 \\
\mathrm{~Np}-237 \\
\mathrm{Pu}-236 \\
\mathrm{Pu}-238 \\
\mathrm{Pu}-239 \\
\mathrm{Pu}-240 \\
\mathrm{Pu}-241 \\
\mathrm{Pu}-242 \\
\mathrm{Am}-241 \\
\mathrm{Am}-242 \\
\mathrm{Am}-243 \\
\mathrm{Cm}-242 \\
\mathrm{Cm}-243 \\
\mathrm{Cm}-244 \\
\mathrm{Cm}-245 \\
\mathrm{Cm}-246\end{array}$ & $\begin{array}{l}9.76(10)-5 \\
2.09(10)-6 \\
9.89(10)-6 \\
5.49(10)-8 \\
3.31(10)-2 \\
3.50(10)-7 \\
4.53(10)-2 \\
0.265 \\
0.340 \\
7.61(10)-2 \\
0.109 \\
4.24(10)-2 \\
2.85(10)-3 \\
0.353 \\
5.27(10)-4 \\
1.45(10)-4 \\
2.00(10)-2 \\
4.78(10)-3 \\
1.97(10)-3\end{array}$ & $\begin{array}{l}2.63(10)-4 \\
1.41(10)-5 \\
2.82(10)-5 \\
1.59(10)-7 \\
2.69(10)-2 \\
4.59(10)-7 \\
4.14(10)-2 \\
0.207 \\
0.314 \\
6.74(10)-2 \\
0.104 \\
3.56(10)-2 \\
2.86(10)-3 \\
0.353 \\
2.94(10)-3 \\
1.50(10)-4 \\
2.06(10)-2 \\
4.78(10)-3 \\
1.98(10)-3\end{array}$ & $\begin{array}{l}1.66(10)-4 \\
1.20(10)-5 \\
1.83(10)-5 \\
1.04(10)-7 \\
(6.17(10)-3) \\
1.09(10)-7 \\
(3.73(10)-3) \\
(5.78(10)-2) \\
(2.67(10)-2) \\
(8.64(10)-3) \\
(5.30(10)-3) \\
(6.58(10)-3) \\
6.42(10)-6 \\
(1.30(10)-3) \\
2.41(10)-3 \\
4.08(10)-6 \\
5.78(10)-4 \\
2.76(10)-6 \\
3.47(10)-6\end{array}$ \\
\hline $\begin{array}{l}\text { Total: } \\
\text { U } \\
\text { Np } \\
\text { Pu } \\
\text { Am } \\
\text { Cm } \\
\text { TRU }\end{array}$ & $\begin{array}{l}1.096(10)-4 \\
3.31(10)-2 \\
0.8354 \\
0.3983 \\
2.74(10)-2 \\
1.294\end{array}$ & $\begin{array}{l}3.055(10)-4 \\
2.69(10)-2 \\
0.7338 \\
0.3915 \\
3.05(10)-2 \\
1.183\end{array}$ & $\begin{array}{l}1.964(10)-4 \\
(6.17(10)-3) \\
(0.1022) \\
(7.87(10)-3) \\
3.00(10)-3 \\
0.113\end{array}$ \\
\hline
\end{tabular}


Input IFR Actinide Flows:

A) Output (to storage):

1) Reprocessed Uranium $1.964(10)-4 \mathrm{~kg} / \mathrm{GW}-\mathrm{hr}$ e

B) Input Required:

1) Total TRU (Gross)

$0.113 \mathrm{~kg} / \mathrm{GW}-\mathrm{hr}_{\mathrm{e}}$

Breakdown:

Np

$\mathrm{Pu}$

Am

$\underline{\mathrm{kg} / \mathrm{GW}-\mathrm{hr}}$

$\mathrm{Cm}$

$$
\begin{aligned}
& \frac{}{6.17(10)-3} \\
& 0.1022 \\
& 7.874(10)-3 \\
& (3.00(10)-3)
\end{aligned}
$$

\section{Mass Flows at Thermal Reactor/IFR Interface}

A) Output from Thermal Reactor

1) Total TRU

Breakdown:
$\mathrm{Np}$
$\mathrm{Pu}$
$\mathrm{Am}$
$\mathrm{Cm}$

B) Input to IFR Actinide Burner

1) Total TRU

Breakdown:

$\mathrm{Np}$
$\mathrm{Pu}$
$\mathrm{Am}$
$\mathrm{Cm}$
$3.75(10)-2 \mathrm{~kg} / \mathrm{GW}-\mathrm{hr}$

$\mathrm{kg} / \mathrm{GW}-\mathrm{hr}$

$2.025(10)-3$

$3.338(10)-2$

$1.875(10)-3$

$2.318(10)-4$
$0.113 \mathrm{~kg} / \mathrm{GW}-\mathrm{hr}$

$\frac{\mathrm{kg} / \mathrm{GW}-\mathrm{hr}}{6.17(10)-3}$

0.1022

$7.874(10)-3$

$(3.00(10)-3)$

- Therefore, approximate power ratio of Thermal Reactors (LWR) to IFR Actinide Burners (based on gross TRU total) is:

$$
\begin{aligned}
& \frac{0.113 \mathrm{~kg} \text { TRU/GW-hr }}{\mathrm{e}} \text { IFR } \\
& \begin{array}{ll}
3.75(10)-2 \mathrm{~kg} \text { TRU } / \mathrm{GW}-\mathrm{hr}_{\mathrm{e}} & \text { Thermal LWR } \\
=3.01 \frac{\mathrm{GW}-\mathrm{hr}}{\mathrm{GW}-\mathrm{hr}} \mathrm{LWR} & - \text { Thermal Reactor } \\
& \text { - Actinide Burner }
\end{array}
\end{aligned}
$$


- Now put all the numbers for Scenario 2 in GW-hr combined Hybrid system (CHS).

Thermal LWR:

$$
\frac{3.01 \mathrm{GW}-\mathrm{hr}}{4.01 \mathrm{GW}-\mathrm{hr}_{\mathrm{e}} \text { CHS }}=0.751 \frac{\mathrm{GW}-\mathrm{hr} \text { Thermal LWR }}{\mathrm{GW}-\mathrm{hr} r_{\mathrm{e}} \text { CHS }}
$$

IFR :

$$
\frac{1.00 \mathrm{GW}-\mathrm{hr}}{4.01 \mathrm{GW}-\mathrm{hr}} \frac{\mathrm{IFR}}{\mathrm{CHS}}=0.249 \frac{\mathrm{GW}-\mathrm{hr}}{\mathrm{GW}-\mathrm{hr}_{\mathrm{e}}}-\mathrm{IFR}
$$

Therefore, each GW-hre of Combined Hybrid system power generation is made up of approximately:

$3 / 4$ Thermal Reactor (LWR) Power; and

1/4 IFR Power. 
Appendix C: Mass Flow Calculations for:

Scenario 3 - Thermal Reactor with PUREX/TRUEX Reprocessing

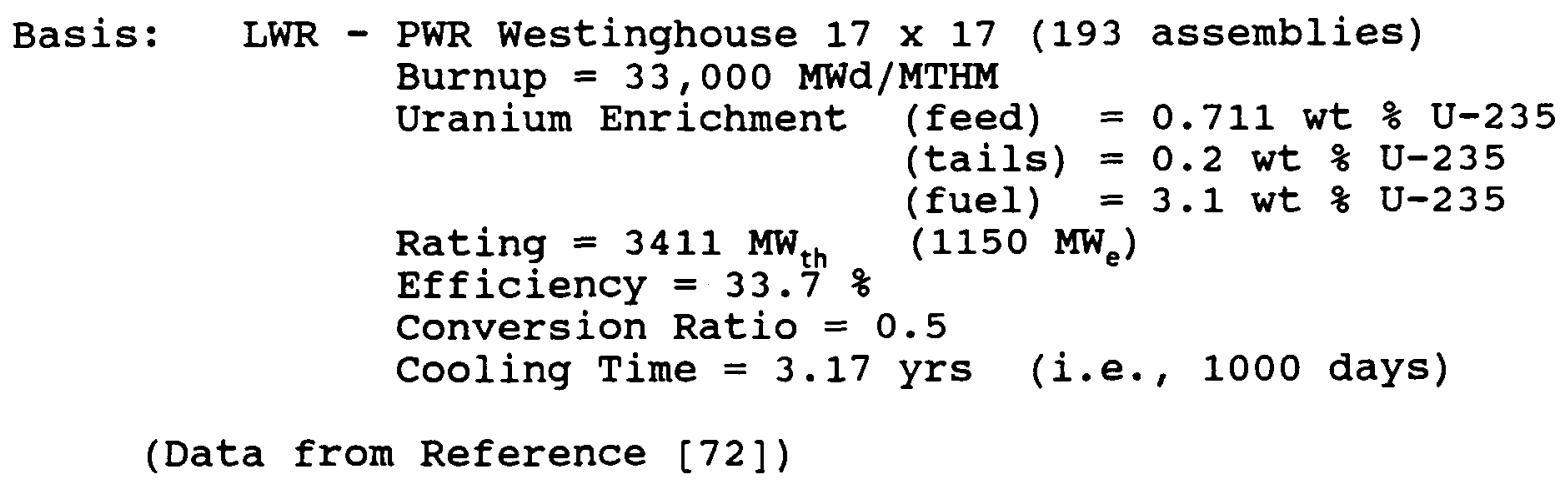

\section{LWR Thermal Reactor}

Uranium Enrichment

$$
\begin{aligned}
\text { Feed } & =0.711 \text { wt } \% \mathrm{U}-235 \\
\text { Tails } & =0.2 \text { wt } \% \mathrm{U}-235 \\
\text { Product } & =3.1 \text { wt } \% \mathrm{U}-235
\end{aligned}
$$

Derivation:

$$
\begin{aligned}
F & =W+P \\
x_{f} F & =x_{w} W+x_{p} P \\
W & =F-P \\
x_{f} F & =x_{w}(F-P)+x_{p} P \\
\left(x_{f}-x_{w}\right) F & =\left(x_{p}-x_{w}\right) P \\
\frac{F}{P} & =\frac{\left(x_{p}-x_{w}\right)}{\left(x_{f}-x_{w}\right)} \\
\frac{F}{P} & =\frac{(3.1-0.2)}{(0.711-0.2)}=5.675
\end{aligned}
$$

Therefore:

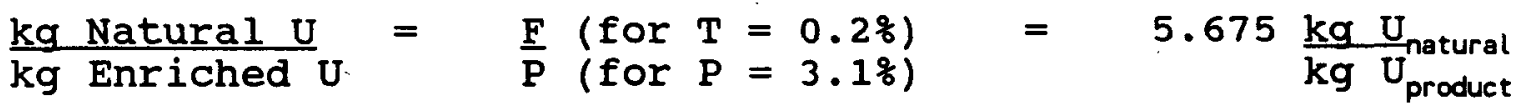




$$
W=F-P=5.675-1=4.675
$$

- Therefore, for every $1 \mathrm{~kg}$ of fuel product (enriched U), there is $4.675 \mathrm{~kg}$ of tails (depleted U) and $5.675 \mathrm{~kg}$ of feed (natural U).

Recall: Burnup $=33,000 \mathrm{MWd} / \mathrm{MTHM}$

$$
\text { Efficiency }=0.337
$$

- Want the number of $\mathrm{kg} U$ charged to reactor per $\mathrm{GW}-\mathrm{hr}$ (i.e., $\mathrm{kg} / \mathrm{GW}-\mathrm{hr}$ )

Note - for a Thermal Reactor charged with only U, 1 MTHM $=1$ MTU

$$
33,000 \frac{\mathrm{MWd}}{\mathrm{MTHM}} \times \frac{1 \mathrm{MTHM}}{1 \mathrm{MTU}} \times \frac{1 \mathrm{MTU}}{1000 \mathrm{~kg} \mathrm{U}}=33 \frac{\mathrm{MWd}}{\mathrm{kg} \mathrm{U}}
$$

$$
33 \frac{\mathrm{MWd}}{\mathrm{kg} \mathrm{U}} \times \frac{1 \mathrm{GW}}{1000 \mathrm{MW}} \times \frac{24 \mathrm{hr}}{1 \mathrm{day}}=0.792 \frac{\mathrm{GW}-\mathrm{hr}}{\mathrm{kg} \mathrm{U}} \text { th }
$$

- Burnup is always given in MWd $_{\text {thermal }}$ (i.e., total energy release per MT fuel). However, we want it in GW-hr - actual electric generation.

$$
\begin{aligned}
& \mathrm{GW}-\mathrm{hr} r_{\mathrm{e}}=\mathrm{n}_{\mathrm{th}} \times \mathrm{GW}-\mathrm{hr} r_{\mathrm{th}} \\
& (0.337) \times 0.792 \frac{\mathrm{GW}-\mathrm{hr}}{\mathrm{kg} \mathrm{U}}=0.267 \frac{\mathrm{GW}-\mathrm{hr}}{\mathrm{kg} U}
\end{aligned}
$$

Therefore:

$$
\begin{aligned}
& 33,000 \frac{\mathrm{MWd}}{\mathrm{MTHM}}=0.267 \frac{\mathrm{GW}-\mathrm{hr}_{\mathrm{e}}}{\mathrm{kg} \mathrm{U}} \text { for } \mathrm{n}_{\mathrm{th}}=0.337 \\
& \frac{\mathrm{kg} \mathrm{U}}{\mathrm{GW}-\mathrm{hr} r_{\mathrm{e}}}=\frac{1}{0.267 \frac{\mathrm{GW}-\mathrm{hr}}{\mathrm{kg} \mathrm{U}}}=3.75 \frac{\mathrm{kg} \mathrm{U}}{\mathrm{GW}-\mathrm{hr}} \quad \begin{array}{r}
\mathrm{U}(3.18) \text { to } \\
\text { Reactor }
\end{array}
\end{aligned}
$$

- This is U product input as fuel to the reactor, i.e., U enriched to 3.1 wt of U-235. 
- Using the Feed to Product to Tails ratios developed above:

1 Product $\alpha 4.675$ Tails $\alpha 5.676$ Feed

Tails: Depleted Uranium $=4.675 \times 3.75 \frac{\mathrm{kg} \mathrm{U}}{\mathrm{GW}-\mathrm{hr}_{\mathrm{e}}}=17.5 \frac{\mathrm{kg} \mathrm{U}}{\mathrm{GW}-\mathrm{hr}_{\mathrm{e}}}$

Feed: Natural Uranium $=5.675 \times 3.75 \frac{\mathrm{kg} \mathrm{U}}{\mathrm{GW}-\mathrm{hr} r_{\mathrm{e}}}=21.3 \frac{\mathrm{kg} \mathrm{U}}{\mathrm{GW}-\mathrm{hr}}$

Thermal Reactor spent Fuel

- Now we need spent fuel isotope data per $\mathrm{kg} U$ fed to reactor for all actinides and fission products.

- Actinides should be aggregated by element: $U, \mathrm{~Np}, \mathrm{Pu}, \mathrm{Am}, \mathrm{Cm}$.

- Fission products should be broken down into chemical groupings (i.e., alkali metals, noble metals, rare earths, etc.).

- All data should be on a per $\mathrm{kg} \mathrm{U}$ fed to reactor (per $\mathrm{kg} \mathrm{U}_{\text {fuel }}$ ) basis which then can be changed to units of $\mathrm{kg} / \mathrm{GW}-\mathrm{hr} \mathrm{e}_{\mathrm{e}}$.

- The data used here is from IFR Document ANL-IFR-127 [42].

- LWR fuel cooled 3.17 years.

- Use Tables III-1, III-4, and V-1 from Reference [42].

- From Table V-1:

Basis 420 MT LWR Fuel with 33,000 MWd/ton

(assume enrichment $3.1 \%$, tails $0.2 \%$ )

Input:
A. Actinides
LWR Fuel (kg/yr)
1) $\mathrm{U}$
400000
2) TRU
4200
Total 404200 
Input (continued):

B. Fission Products

1) Alkali Metals

2) Alkaline Earths

3) Rare Earths

4) Noble Metals

5) Halides

6) Fission Gases

Total
LWR Fuel (kg/yr)

1230

1080

4500

5400

100

2450

14760

Total (Actinide plus Fission Products)

418960

Therefore, other fission products = $\begin{aligned} 420000 & \begin{array}{c}\text { (Total) } \\ \text { (Totinides +F.P.S) } \\ \text { (Other F.P.s) }\end{array}\end{aligned}$

- Put on basis of $\mathrm{kg} / \mathrm{GW}-\mathrm{hr} r_{\mathrm{e}}$.

- First, find weight $z$ of total (i.e., divide by 420000)

A. Actinides

1) $U$

2) TRU
LWR Fuel $(\mathrm{kg} / \mathrm{kg} U)$

0.952

$\underline{0.010}$

Total

0.962 
B. Fission Products

1) Alkali Metals

2) Alkaline Earths

3) Rare Earths

4) Noble Metals

5) Halides

6) Fission Gases

7) Other Fission

Products
LWR Fuel $(\mathrm{kg} / \mathrm{kg}$ U)

0.00293

0.00257

0.01071

0.01286

0.000238

0.00583

$\underline{0.00248}$

Total 0.0351

Total (Actinide plus

Fission Products)

$0.997-1.00$

- Want to put mass flows in terms of $\mathrm{kg} / \mathrm{GW}-\mathrm{hr}_{\mathrm{e}}$.

- All are on basis of $\mathrm{kg} / \mathrm{kg} \mathrm{U}$.

- Multiply by $3.75 \mathrm{~kg} \mathrm{U} / \mathrm{GW}-\mathrm{hr}$ e to get $\mathrm{kg} / \mathrm{GW}-\mathrm{hr} r_{\mathrm{e}}$.

LWR Spent Fuel Constituents

(Cooling Time $=3.17$ years)

A. Actinides

1) $U$

2) TRU $\mathrm{kg} / \mathrm{GW}-\mathrm{hr}$

3.57

$\underline{0.0375}$ 
LWR Spent Fuel Constituents (continued):

$\begin{array}{lc}\text { B. Fission Products } & \underline{\mathrm{kg} / \mathrm{GW}-\mathrm{hr}_{\mathrm{e}}} \\ \text { 1) Alkali Metals } & 0.0110 \\ \text { 2) Alkaline Earths } & 0.00964 \\ \text { 3) Rare Earths } & 0.0402 \\ \text { 4) Noble Metals } & 0.0482 \\ \text { 5) Halides } & 0.000893 \\ \text { 6) Fission Gases } & 0.0219 \\ \text { 7) Other Fission } & 0.00930 \\ \text { Fission Product Total } & 0.1411\end{array}$

LWR Spent Fuel Constituents (in $\mathrm{kg} / \mathrm{GW}-\mathrm{hr} \mathrm{r}_{\mathrm{e}}$ )

1) Reprocessed U

2) Fission Products

i) Fission Gases

ii) Remaining Fission Products

3) Transuranics (TRU)
$3.57 \mathrm{~kg} / \mathrm{GW}-\mathrm{hr}$ e $0.1411 \mathrm{~kg} / \mathrm{GW}-\mathrm{hr}_{\mathrm{e}}$ $0.0219 \mathrm{~kg} / \mathrm{GW}-\mathrm{hr}$ $0.1192 \mathrm{~kg} / \mathrm{GW}-\mathrm{hr} r_{\mathrm{e}}$ $0.0375 \mathrm{~kg} / \mathrm{GW}-\mathrm{hr}$ e 
Transuranics (TRU) in LWR Fuel

- Using the TRU data from ANL-IFR-127 [42] Table III-4, determine the TRU content of LWR spent fuel.

LWR Fuel Burnup $=33,000 \mathrm{MWd} / \mathrm{MTHM}$

Cooling Time $=3.17$ yrs

Total TRU $=0.0375 \mathrm{~kg} / \mathrm{GW}-\mathrm{hr} r_{\mathrm{e}}$

$\begin{array}{lll}\text { TRU Isotope } & \begin{array}{l}\text { Wt. Fraction of } \\ \text { Total TRU }\end{array} & \text { kg/GW-hr } \\ \text { Np-237 } & 5.40(10)-2 & 2.025(10)-3 \\ \text { Pu-236 } & 1.12(10)-7 & 4.20(10)-9 \\ \text { Pu-238 } & 1.01(10)-2 & 3.79(10)-4 \\ \text { Pu-239 } & 0.508 & 1.905(10)-2 \\ \text { Pu-240 } & 0.199 & 7.46(10)-3 \\ \text { Pu-241 } & 0.134 & 5.025(10)-3 \\ \text { Pu-242 } & 3.88(10)-2 & 1.455(10)-3 \\ \text { Total Pu } & 0.890 & 3.338(10)-2 \\ \text { Am-241 } & & \\ \text { Am-242 } & 2.51(10)-2 & 9.41(10)-4 \\ \text { Am-243 } & 1.11(10)-4 & 4.16(10)-6 \\ \text { Total Am } & 2.48(10)-2 & 9.30(10)-4 \\ \text { Cm-242 } & 5.00(10)-2 & 1.875(10)-3 \\ \text { Cm-243 } & & \\ \text { Cm-244 } & 9.73(10)-6 & 3.65(10)-7 \\ \text { Cm-245 } & 7.86(10)-5 & 2.95(10)-6 \\ \text { Cm-246 } & 5.52(10)-3 & 2.07(10)-4 \\ \text { Total Cm } & 5.08(10)-4 & 1.905(10)-5 \\ & 6.31(10)-5 & 2.366(10)-6 \\ & 6.18(10)-3 & 2.318(10)-4\end{array}$

TRU in LWR spent Fuel - Summary

PWR Westinghouse $17 \times 17$

Burnup $=33,000 \mathrm{MWd} / \mathrm{MTHM}$

Cooling Time $=3.17 \mathrm{yrs}$

Total TRU

Total Np

$3.75(10)-2 \mathrm{~kg} / \mathrm{GW}-\mathrm{hr}_{\mathrm{e}}$

Total Pu

$2.025(10)-3 \mathrm{~kg} / \mathrm{GW}-\mathrm{hr}_{\mathrm{e}}$

Total Am

$3.338(10)-2 \mathrm{~kg} / \mathrm{GW}-\mathrm{hr}_{\mathrm{e}}^{\mathrm{e}}$

Total cm

$1.875(10)-3 \mathrm{~kg} / \mathrm{GW}-\mathrm{hr}_{\mathrm{e}}^{\mathrm{e}}$

Plus

$2.318(10)-4 \mathrm{~kg} / \mathrm{GW}-\mathrm{hr}_{\mathrm{e}}$

Total U

$3.57 \mathrm{~kg} / \mathrm{GW}-\mathrm{hr}_{\mathrm{e}}$ 


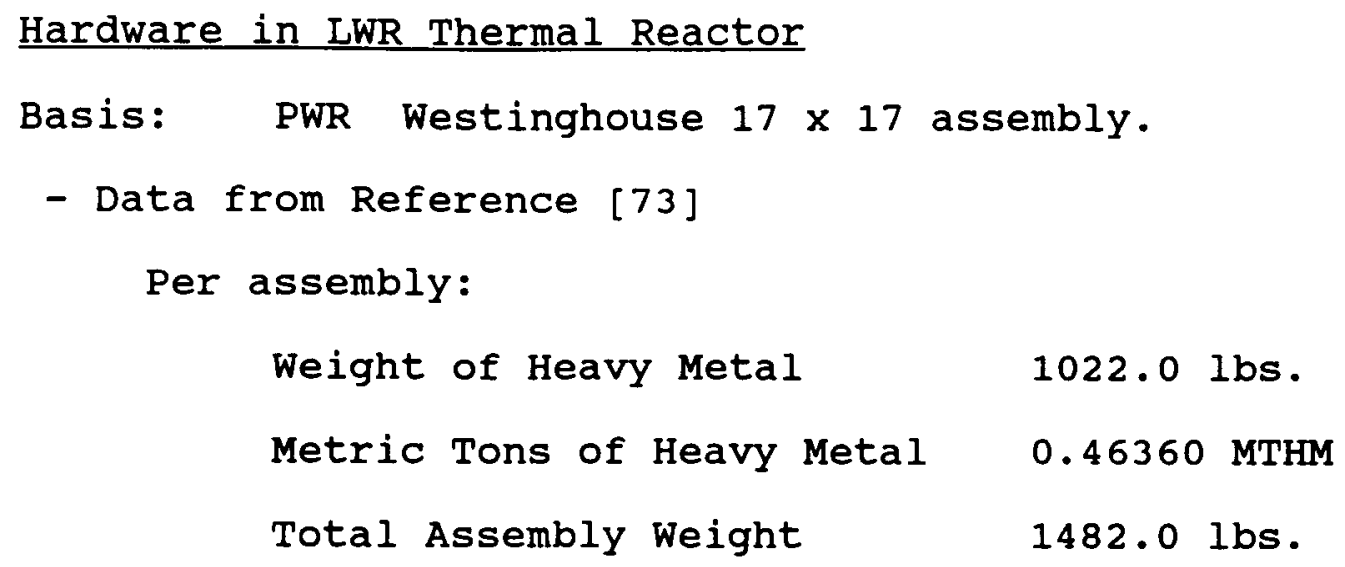

